\title{
36. CENOZOIC PLANKTONIC DIATOM BIOSTRATIGRAPHY OF THE SOUTHERN PACIFIC OCEAN
}

\author{
Hans-Joachim Schrader, Geologisch-Paläontologisches Institut und Museum \\ der Universität Kiel, Kiel, F.R. Germany
}

\section{INTRODUCTION}

Leg 35 of the Deep Sea Drilling Project (MarchApril 1974) began in Lima, Peru and ended in Ushuaia, Argentina. During this time, two sites were drilled on the Bellingshausen Abyssal Plain and two on the Antarctic continental rise. The sites were not continuously cored, therefore a completed biostratigraphic study was not possible.

The biostratigraphic zonation established during Leg 28 was used for the Quaternary through late Miocene interval and a zonation, established during Leg 29, was used for the late Miocene through Oligocene interval. Zonations established by Donahue (1970a) and Abbott (1972, in press) for the Quaternary were also used.

The diatom content and abundance vary with location and age and reflect changes in sedimentological and environmental regime through time. Site information is listed in Table 1 and Figure 1.

The Antarctic Ocean is a body of cold water separated from the warmer Subantarctic water by the Antarctic Polar Front (APF). This represents a separation of high phytoplankton production in the south from an area of low phytoplankton production in the north (Balech et al., 1968). The diatom flora north and south of the APF are similar (Hargraves, 1968; Hasle, 1969). Taxonomy and distribution of Antarctic planktonic diatoms have been studied in a series of expedition reports (Table 2, Figure 2). Species distribution and taxonomy of diatoms in Antarctic sediments were studied by Kozlova (1964), Donahue (1970a), and Abbott (1972, in press). Main areas of study which have been used for correlation are shown in Figure 3. Stratigraphic studies of Antarctic sediments were made by Jousé et al. (1963), on a south Indian Ocean core, by Donahue (1970a) on piston core material of the western Bellingshausen Sea area, by Abbott (1972, in press) on piston cores of the southern Indian Ocean, and by McCollum (1975) on drill material from the Ross Sea. Locations of important sites and cores are shown in Figure 1.

\section{PREPARATION OF SAMPLES}

Approximately $3 \mathrm{ml}$ of sample were heated for 20 min with an equal mixture of concentrated acetic acid and hydrogen peroxide. The suspension was then centrifuged in 50-ml centrifuge tubes at a speed of 1300 rpm for $2 \mathrm{~min}$, decanted, then washed with demineralized water. Washing was repeated five times to remove most of the clay-sized fraction. The residue was mixed with a 0.5 solution of sodium pyrophosphate, centrifuged, then washed three times. The resulting residue was stored in demineralized water to which a few drops of formaldehyde had been added to prevent bacterial activity (Schrader, 1974b).

To prepare a slide, 1 to 3 drops of residue were pipetted using disposable plastic tips (Stradner and Papp, 1961) and placed on an $18 \times 18 \mathrm{~mm}$ cover glass with a thickness of less than $0.17 \mathrm{~mm}$ and, after drying, mounted in Aroclor No. 4465 (refractive index 1.66; Schrader, 1969). The cover glass was then heated at a temperature of approximately $100^{\circ} \mathrm{C}$ until the medium hardened upon cooling. The cover glass was then lifted onto a heated slide. For a more detailed description see Hustedt, 1924; Schrader, 1973a, 1974b, 1974c).

Specimens were studied with a Leitz orthoplan light microscope with apochromatic optics. Micrographs were made using an automatic Leitz Orthomat camera. Individuals on the plates are pictured at $1500 \times$ magnification except for a few at $600 \times$ magnification.

All samples and slides were prepared aboard the Glomar Challenger.

\section{DIATOMS AT EACH SITE}

\section{Site 322}

Site 322 is located on the Bellingshausen Abyssal Plain at a water depth of 5026 meters. Five lithologic units, four sedimentary and one igneous, are recognized. Unit 1 is approximately 295 meters thick and consists of unconsolidated, well-sorted sands and silts interbedded with clays. Quartz is more abundant than feldspar in the sands; few rock fragments and no volcanic glass were observed. Diatoms and sponge spicules are common. The contact with Unit 2 occurs in the interval occupied by Core 3 , but a complete core was not recovered, therefore the contact was not preserved. Unit 2 is about 170 meters thick and consists of consolidated, dark greenish-gray claystone. Quartz silt is abundant in some beds, whereas feldspar grains, heavy minerals, and diatom fragments are minor components. The contact with Unit 3 was not recovered. Unit 3 is about 43 meters thick and consists of interbedded dark gray sandstones and claystones. The sandstones are poorly to moderately sorted and contain many rock fragments and some volcanic glass fragments; feldspar is about as abundant as quartz. Diatoms and sponge spicules are rare. Unit 4 is 4.3 meters of a distinctive yellowish-brown claystone; arenaceous foraminifera are present in this unit. Neither the upper nor lower contacts are preserved in the cores.

A few diagnostic diatom specimens were found in cleaned and sieved material from Samples 322-11-5, 40$41 \mathrm{~cm}$ and $322-13-2,130 \mathrm{~cm}$. These include: Thalassiosira oestrupii, Actinocyclus curvatulus, Thalassiosira cf. 
TABLE 1

Leg 28, 29, and 35 Site Data

\begin{tabular}{lccccccl}
\hline & & \multicolumn{9}{c}{ Position } & $\begin{array}{c}\text { Water } \\
\text { Depth } \\
(\mathrm{m} \text { from } \\
\text { Leg }\end{array}$ & Site & Latitude & Longitude & $\begin{array}{c}\text { Penetration } \\
(\mathrm{m})\end{array}$ & $\begin{array}{l}\text { No. of } \\
\text { Cores }\end{array}$ & Age of Oldest Sediment Cored \\
\cline { 2 - 8 } 28 & 266 & $56^{\circ} 24.13^{\prime} \mathrm{S}$ & $110^{\circ} 06.70^{\prime} \mathrm{E}$ & 4167 & 384 & 24 & Upper Oligocene (?) \\
28 & 269 & $61^{\circ} 40.57^{\prime} \mathrm{S}$ & $140^{\circ} 04.21^{\prime} \mathrm{E}$ & 4282 & 958 & 24 & At least as old as middle Oligocene \\
28 & 274 & $68^{\circ} 59.81^{\prime} \mathrm{S}$ & $173^{\circ} 25.64^{\prime} \mathrm{E}$ & 3305 & 421 & 45 & \\
29 & 278 & $56^{\circ} 33.42^{\prime} \mathrm{S}$ & $160^{\circ} 04.29^{\prime} \mathrm{E}$ & 3675 & 4385 & 35 & Middle Oligocene \\
35 & 322 & $60^{\circ} 01.45^{\prime} \mathrm{S}$ & $79^{\circ} 25.49^{\prime} \mathrm{W}$ & 5026 & 544 & 14 & (?) Oligocene to early Miocene \\
$\mathrm{B} 5$ & 323 & $63^{\circ} 40.84^{\prime} \mathrm{S}$ & $97^{\circ} 59.69^{\prime} \mathrm{W}$ & 5004 & 731 & 21 & Late Cretaceous \\
35 & 324 & $69^{\circ} 03.21^{\prime} \mathrm{S}$ & $98^{\circ} 47.20^{\prime} \mathrm{W}$ & 4433 & 218 & 10 & Pliocene \\
35 & 325 & $65^{\circ} 02.79^{\prime} \mathrm{S}$ & $73^{\circ} 40.40^{\prime} \mathrm{W}$ & 3748 & 718 & 10 & (?) Oligocene to early Miocene \\
\hline
\end{tabular}

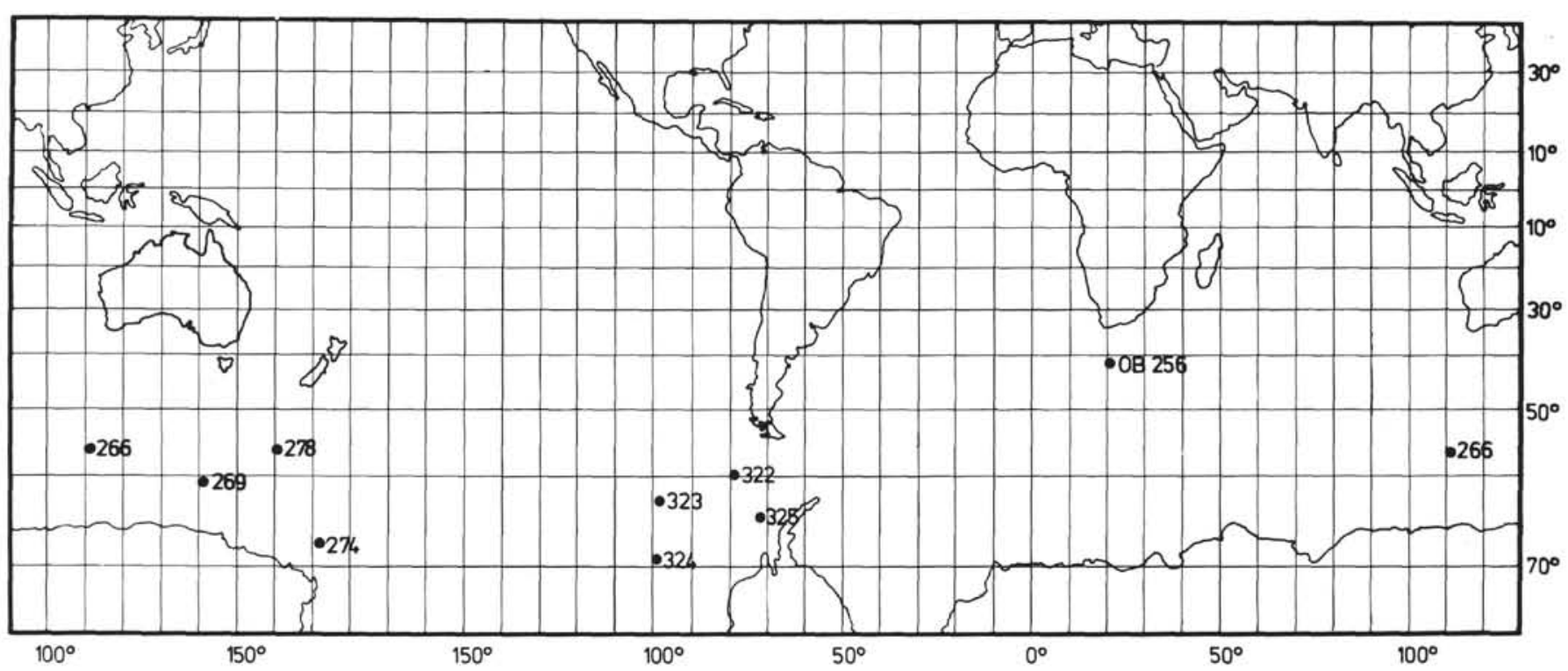

Figure 1. Location of DSDP Leg 28, 29, and 35 sites.

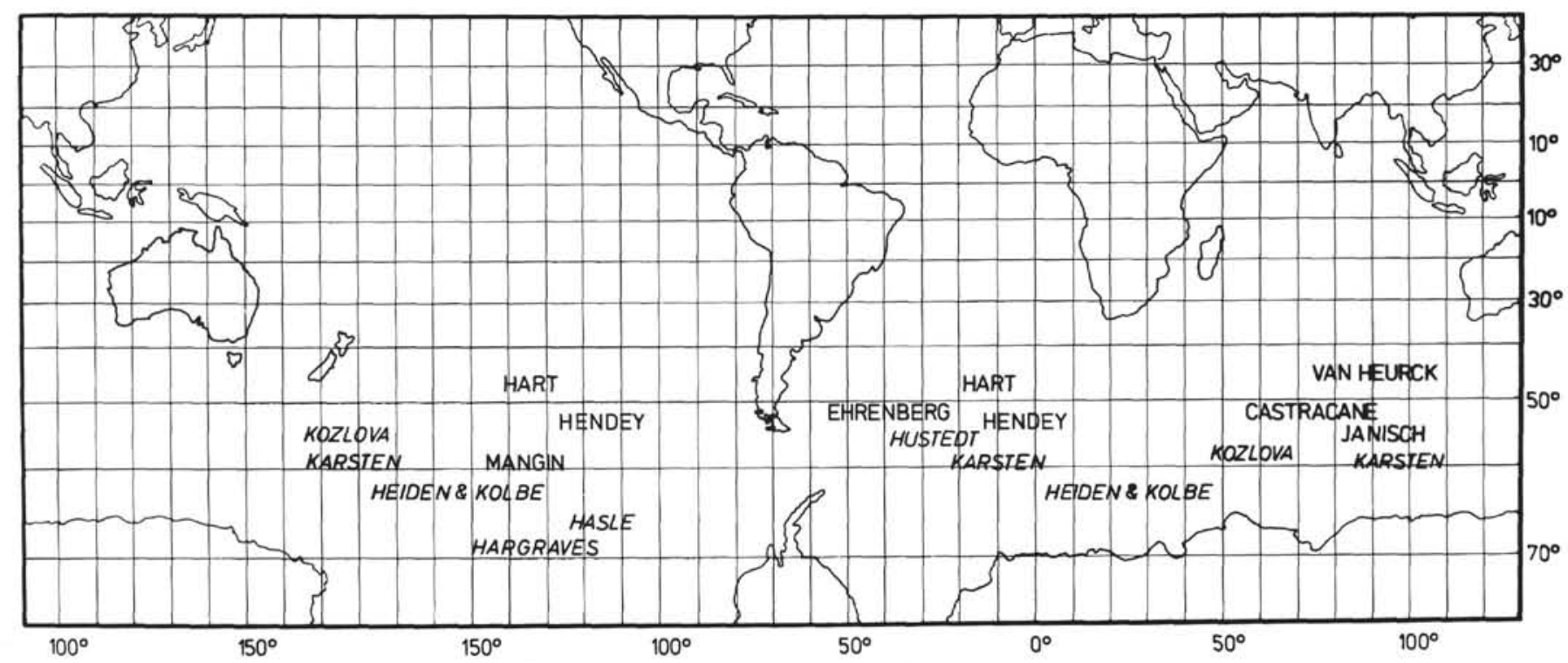

Figure 2. Recent phytoplankton studies in the Southern Ocean. 


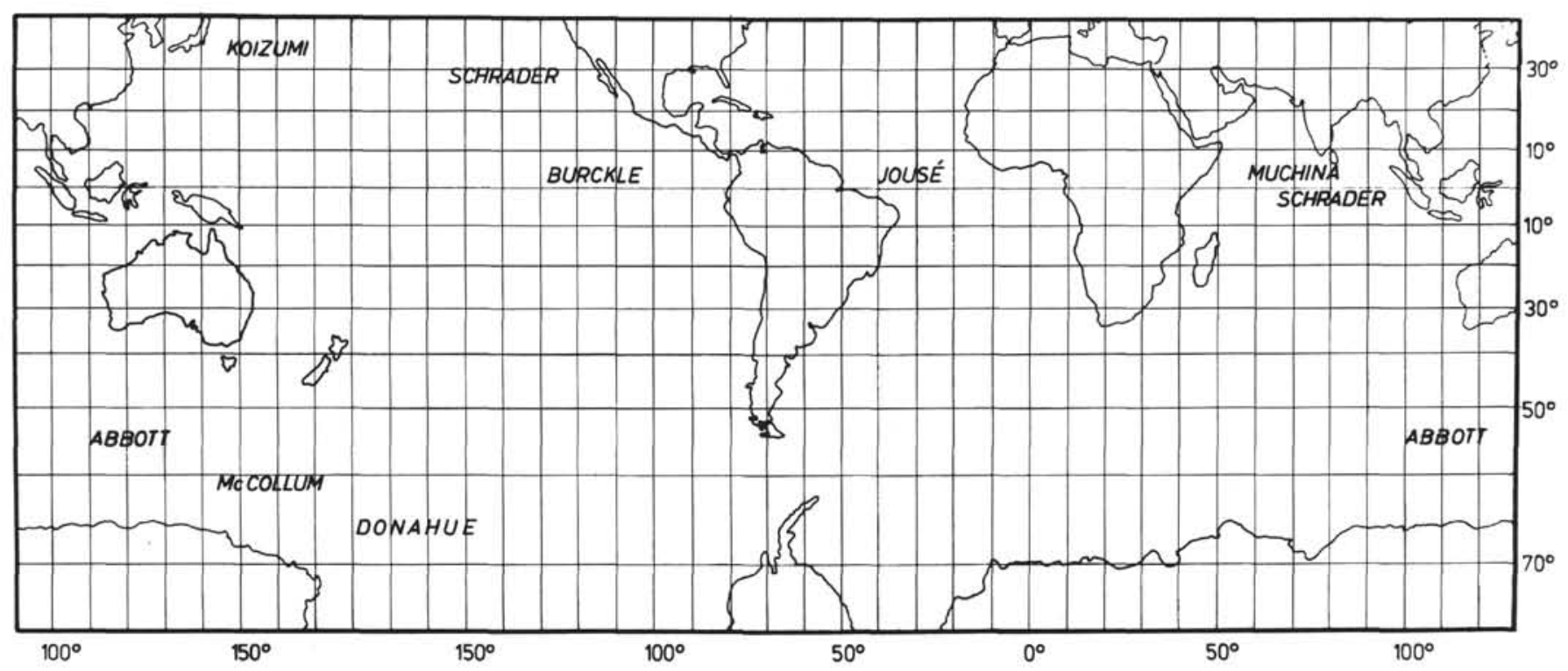

Figure 3. Established Quaternary-Tertiary marine planktonic diatom zonations.

decipiens, Roperia tesselata (centric form), and displaced Synedra ulna (fresh-water, planktonic). $T$. oestrupii evolved from $T$. nativa within North Pacific Diatom (NPD) Zone IX (base), which in turn is correlative with foraminifera Zone N 18. Roperia tesselata evolved from Roperia praetesselata at about the same time in tropical to subtropical sequences. Thus it would seem that Sample 322-11-5, 40-41 cm is not older than the uppermost Miocene and is most probably early Pliocene. The above-mentioned occurrences are scarce and to ensure that their presence was not caused by downhole displacement or contamination the same type of sample was taken from $322-11-5,89-90 \mathrm{~cm}$ and $322-11-5,134-135 \mathrm{~cm}$. Only $322-11-5,89-90 \mathrm{~cm}$ had one fragment of displaced Synedra ulna found within five slides. The above-mentioned species are rare in comparison to mass occurrences of Rhizosolenia, Nitzschia, etc., which would appear if contamination from recent material had occurred, furthermore, the other two samples should also have been contaminated. A second control test was run with a sample (consisting of alternating brown to black clay layers) from 322-11-5, 40-41 $\mathrm{cm}$. A few tests of the same species were found, which should prove that the original sample was uncontaminated.

A stratigraphic summary is given in Table 3. The youngest material recovered $(322-1-1,79-80 \mathrm{~cm})$ is placed in the Nitzschia interfrigidaria Zone of McCollum (1975) which is correlated to the stratigraphy and is of 2.8-3.65 m.y.B.P. on the basis of common Nitzschia interfrigidaria, Cosmiodiscus insignis, and Coscinodiscus lentiginosus. Samples 322-1-2, 61-62 $\mathrm{cm}$ through $322-2-2,141-142 \mathrm{~cm}$ are placed into the Nitzschia interfrigidaria-Nitzschia praeinterfrigidaria zones of McCollum (1975) on the basis of the occurrence of Cosmiodiscus insignis even though no specimens of Nitzschia praeinterfrigidaria or N. interfrigidaria were found. An age of 3.65-3.82 m.y.B.P. can be assigned to this interval. Samples 2, CC through 4, $\mathrm{CC}$ contain a poorly preserved diatom assemblage with common Denticula hustedtii, and Trinacria excavata.
These are placed into the Denticula hustedtii Zone of McCollum (1975), which is lowermost Pliocene to late Miocene in age.

In sediments of the North Pacific representing cold biofacies, Denticula lauta ranges into the upper part of the late Miocene and becomes extinct at approximately 5.5 m.y.B.P. The same extinction date is used for determination of the last occurrence of this species in the Antarctic (322-4, CC).

The first trace of diatom-bearing sediment was found in 6, CC. Several individuals of Rhizosolenia hebetata forma hiemalis were found. This species ranges through the Miocene into the Recent, therefore a precise age cannot be calculated on the basis of its occurrence. Age determinations on samples from Cores 7 to 13 were not possible due to lack of diatoms. Samples barren of diatoms are listed in Table 4.

Sedimentation rates for the upper 300 meters of material at Site 322 are calculated to be $5 \mathrm{~cm} / 1000 \mathrm{yr}$ (Figure 4).

\section{Site 323}

Site 323 is located near the southern margin of the Bellingshausen Abyssal Plain. Six lithologic units are recognized: five sedimentary and one igneous. Unit 1 is about 266 meters thick and consists of gray unconsolidated sandy silts, diatom clay, and diatom ooze. Unit 2 is about 241 meters thick and consists of relatively indurated gray diatomaceous claystone and cherts. Unit 3 is about 130 meters thick and consists of gray claystone devoid of biogenic silica. Unit 4 is about 28 meters thick and is composed of yellowish-brown iron-rich claystone and nanno claystone overlying Unit 5 which is 34 meters of brown zeolitic claystone devoid of opaline silica tests.

Diatoms occurring in the interval $323-1-1,60-61 \mathrm{~cm}$ to $323-10-3,47-48 \mathrm{~cm}$ are generally well to moderately well preserved and have moderate to high species diversity. The species assemblage belongs to the AntarcticSubantarctic assemblage of Jousé and Kozlova (1971). Detailed climatic interpretations are not possible 
TABLE 2

Major Expedition Reports on Antarctic Diatoms

\begin{tabular}{|c|c|c|c|}
\hline Author & Expedition & $\begin{array}{l}\text { Region of } \\
\text { Collection }\end{array}$ & $\begin{array}{c}\text { Date of } \\
\text { Publication }\end{array}$ \\
\hline Ehrenberg & $\begin{array}{l}\text { Ross Expedition } \\
1839-1843\end{array}$ & $\begin{array}{l}\text { Around Kerguelen } \\
\text { Island, Falkland } \\
\text { Island, Tierra del } \\
\text { Fuego }\end{array}$ & $1844-1854$ \\
\hline Castracane & $\begin{array}{l}\text { "Challenger" } \\
\text { Expedition } \\
1873-1876\end{array}$ & Indian Ocean & 1886 \\
\hline Janisch & $\begin{array}{l}\text { "Gazelle" } \\
\text { Expedition } \\
1874-1876\end{array}$ & Indian Ocean & 1891 \\
\hline Van Heurk & $\begin{array}{l}\text { "Belgica" } \\
\text { Expedition } \\
1897-1899\end{array}$ & $\begin{array}{l}\text { Southern Indian } \\
\text { Ocean }\end{array}$ & 1909 \\
\hline Karsten & $\begin{array}{l}\text { German Deep Sea } \\
\text { Expedition } \\
\text { "Valdivia" } \\
1898-1899\end{array}$ & Southern Ocean & 1905 \\
\hline Mangin & $\begin{array}{l}\text { Antarctic } \\
\text { Expedition } \\
\text { "Scotia" } \\
1902-1904\end{array}$ & South Pacific & 1915 \\
\hline $\begin{array}{l}\text { Heiden und } \\
\text { Kolbe }\end{array}$ & $\begin{array}{l}\text { German South } \\
\text { Pole Expedition } \\
1901-1903\end{array}$ & Southern Ocean & 1928 \\
\hline Peragallo & $\begin{array}{l}\text { 2nd. French } \\
\text { Antarctic Exped- } \\
\text { ition 1908-1910 }\end{array}$ & Southern Ocean & 1921 \\
\hline Hart & $\begin{array}{l}\text { "Discovery" } \\
1929-1931\end{array}$ & $\begin{array}{l}\text { Southern Atlantic } \\
\text { and Pacific oceans }\end{array}$ & $\begin{array}{l}1934 \\
1942\end{array}$ \\
\hline Hendey & $\begin{array}{l}\text { "Discovery" } \\
1929-1932\end{array}$ & $\begin{array}{l}\text { Southern Atlantic } \\
\text { and Pacific oceans }\end{array}$ & 1937 \\
\hline Hasle & $\begin{array}{l}\text { Norvegian } \\
\text { Expedition } \\
1947-1948\end{array}$ & $\begin{array}{l}\text { South Pacific } \\
\text { Ocean }\end{array}$ & 1969 \\
\hline Manguin & $\begin{array}{l}\text { "Commandant } \\
\text { Charcot" } \\
1949-1950\end{array}$ & $\begin{array}{l}\text { Around Adelie } \\
\text { Land and Herd } \\
\text { Island }\end{array}$ & 1960 \\
\hline Hustedt & $\begin{array}{l}\text { German Antarctic } \\
\text { Expedition } \\
1938-1939\end{array}$ & $\begin{array}{l}\text { Southern Atlantic } \\
\text { Ocean }\end{array}$ & 1958 \\
\hline Kozlova & $\begin{array}{l}\text { M/V "Ob" } \\
1955-1959\end{array}$ & $\begin{array}{l}\text { Southern Indian } \\
\text { and Pacific oceans }\end{array}$ & 1964 \\
\hline
\end{tabular}

because of an incomplete section. Diatoms are poorly preserved at $11-2,69-70 \mathrm{~cm}, 118-119 \mathrm{~cm}, 14-1,100-101$ $\mathrm{cm}, 16-4,22-23 \mathrm{~cm}, 17-1,16-17 \mathrm{~cm}, 18-4,17-18 \mathrm{~cm}$, and $18-4,67-68 \mathrm{~cm}$. Barren samples are listed in Table 5.

Certain diatoms, including Coscinodiscus cf. symbolophorus, Actinocyclus ehrenbergii, and Charcotia actinochilus, in cores containing Cretaceous foraminifera $(16-4,17-1,17-4,18-4)$ suggest downhole contamination. A flora with almost identical species was encountered at 3-2, 32-33 cm. Moreover, diatoms have never been found in Cretaceous recrystallized radiolarian-bearing sediments. The occurrence of a diatom assemblage below the chert-bearing sediment sequence in 8 , CC is also interpreted as downhole contamination. Generally the diatom assemblage disappears gradually as opal is mobilized to form chert. All samples containing diatoms below the chert layers are mixed with younger downwashed material. The chert contained a few ghost shapes of radiolarian tests and is most probably of biogenic origin.

Displaced shallow water benthonic and/or neritic species were found in almost all samples but with a considerable increase at $8, \mathrm{CC}, 9, \mathrm{CC}, 10-3,47-48 \mathrm{~cm}$, and $11-2,69-70 \mathrm{~cm}$ including mass occurrences of Melosira sulcata, Stephanopyxis turris, Diploneis sp., Cocconeis, and various other species.

Displaced fresh-water diatoms occur in 8, CC including Pinnularia nobilis, which inhabits fresh-water lakes in temperate climatic areas. This occurrence may aid in interpretation of Antarctic Miocene climate.

The following biostratigraphic interpretation (Figure 5 and Table 6) is tentative due to spot coring, poor recovery and core disturbance and displacement.

Pliocene sediments were encountered from 1-2, 55-56 $\mathrm{cm}$ to $2-1,46-47 \mathrm{~cm}$ and are characterized by abundant Nitzschia interfrigidaria, Nitzschia praeinterfrigidaria, and Cosmiodiscus insignis. The occurrence of these species permits placement of all samples above 1-4, 69$70 \mathrm{~cm}$ into the Nitzschia interfrigidaria Zone of McCollum (1975), which has been dated by correlation with paleomagnetic stratigraphy and the radiometric time scale as 2.8-3.65 m.y. in age. Samples below 1-4, $109-110 \mathrm{~cm}$ to approximately $2-1,46-47 \mathrm{~cm}$ are located in the Nitzschia praeinterfrigidaria Zone of McCollum (1975). This has been dated by correlation to the paleomagnetic stratigraphy and radiometric time scale as 3.65 to approximately $4.5 \mathrm{~m} . \mathrm{y}$. in age and is thus very close to the Miocene-Pliocene boundary as defined in this report at the boundary of Magnetic Epoch 5 and the Gilbert Reverse Epoch. Samples derived from Core 3 are tentatively placed into the Denticula hustedtii Zone and Denticula hustedtii-Denticula lauta Zone of McCollum (1975), which are correlative to the Hemidiscus karstenii and Coscinodiscus yabei zones (this paper) and to NPD Zones XVII/XVIII (Schrader, 1973a). These zones are of lower late Miocene age with an approximate absolute age of 10-12 m.y. Samples derived from Cores 4 through 7 are placed into the Denticula antarctica-Coscinodiscus lewisianus Zone of McCollum (1975), which is of lower middle Miocene age. This interpretation is sustained by the cooccurrence of Raphidodiscus marylandicus which is short ranging and restricted to the NPD Zones XXXXII. $R$. marylandicus is found at $6-1,137-138 \mathrm{~cm}, 6$, $\mathrm{CC}$ and 7, CC. Denticula nicobarica becomes extinct in the North Pacific at the base of NPD Zone XIX (correlative to foram Zone N10, middle middle Miocene). D. nicobarica was found in 7, CC dating this sample as middle middle Miocene or early Miocene. It is tentatively placed here near the middle/early Miocene boundary, which is approximately 15 m.y.B.P. on the Berggren (1969) time scale.

\section{Site 324}

Site 324 is located on the upper Antarctic continental rise, about 75 miles north of the base of the continental slope. The sediments recovered in Cores 1 through 9 consist predominantly of terrigenous clays and silty clays with thin layers of well-sorted silt. Small portions of Cores 1, 4, and 9 are composed of diatom ooze to diatom-bearing hemipelagic clays. Species recovered from these cores are listed in Table 7. All other material 
TABLE 3

Distribution of Diatoms at Site 322

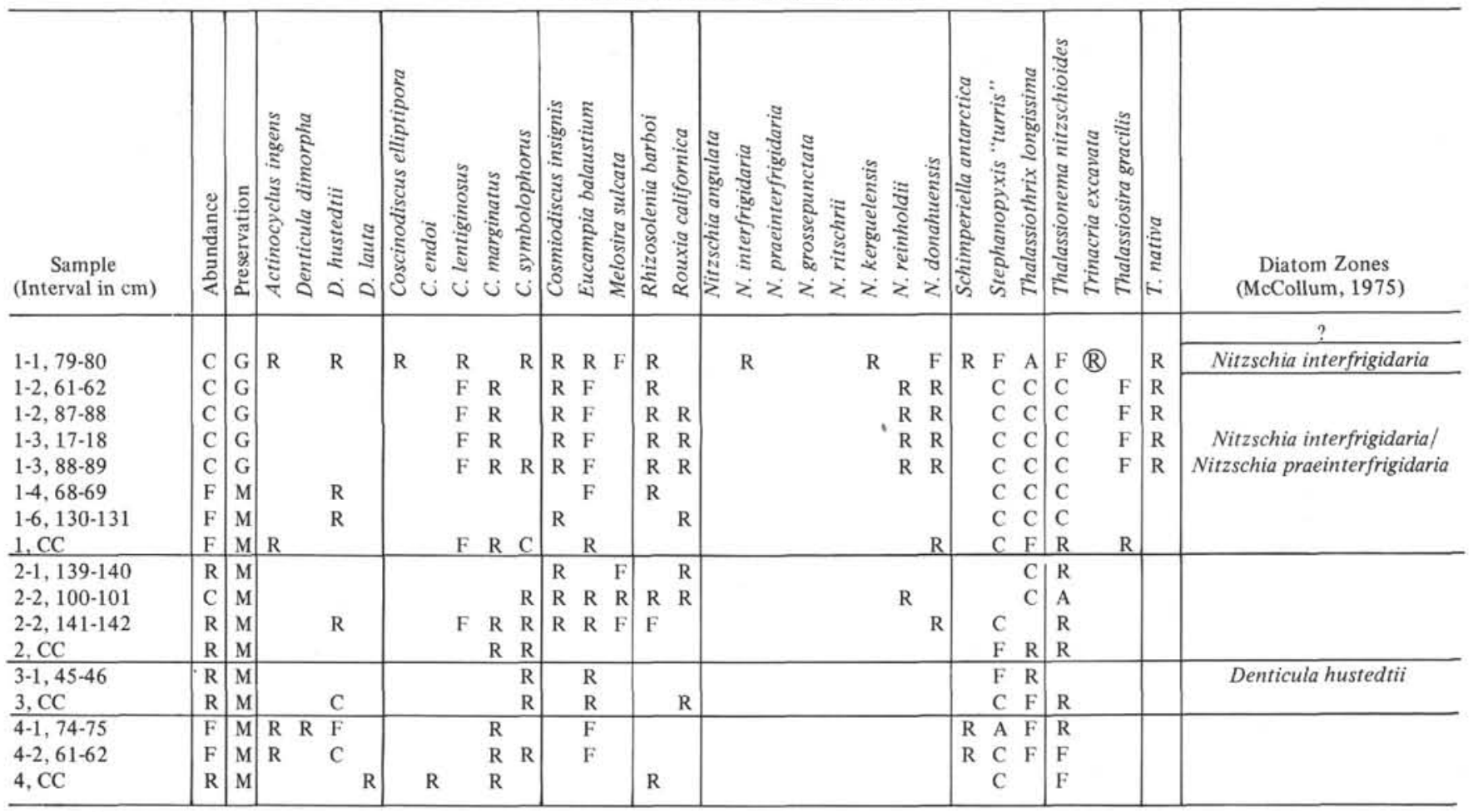

Note: $\mathrm{O}=$ reworked, $\mathrm{R}=$ rare, $\mathrm{F}=$ few, $\mathrm{C}=$ common, $\mathrm{A}=$ abundant.

TABLE 4

Samples Barren of Diatoms at Site 322

\begin{tabular}{lll}
\hline $6-1,2$ & $11-5,42$ & $11-6,27.5$ \\
$6-1,36$ & $11-5,43$ & $11-6,44$ \\
$6-1,137$ & $11-5,59$ & $11-6,62$ \\
6, CC & $11-5,68.5$ & $11-6,66$ \\
7, CC & $11-5,80$ & $11-6,77$ \\
8, CC & $11-5,89-90^{\mathrm{a}}$ & $11-6,78$ \\
$9, \mathrm{CC}$ & $11-5,90$ & $11-6,86$ \\
$11-4,31$ & $11-5,123$ & $11-6,88$ \\
$11-4,63.5$ & $11-5,124$ & $11-6,97.5$ \\
$11-4,92$ & $11-5,125$ & $11-6,107$ \\
$11-4,123$ & $11-5,126.5$ & $11-6,110.5$ \\
$11-4,127$ & $11-5,134-135$ & $11-6,117$ \\
$11-5,13$ & $11-5,135$ & $11-6,125$ \\
$11-5,24.5$ & $11-6,5$ & $11-6,131$ \\
$11-5,35$ & $11-6,16.5$ & $11, \mathrm{CC}$ \\
$11-5,40^{\mathrm{a}}$ & $11-6,22$ & $13, \mathrm{CC}$ \\
\hline
\end{tabular}

${ }^{\mathrm{a}}$ Trace occurrence of diatoms displaced, by coring procedure.

studied contains no diatoms and samples are listed in Table 8.

Core 1, from Section 1, $141 \mathrm{~cm}$ to Section 4, $37 \mathrm{~cm}$ belongs to the Nitzschia kerguelensis Zone of Abbott (in press), which has been correlated to the uppermost part of the Brunhes Normal epoch, to the Fragilariopsis kerguelensis Partial-Range Zone of Donahue (1970a), which has been dated as .35 m.y. to the Recent, and to the Coscinodiscus lentiginosus Partial-Range Zone of McCollum (1975). Reworked older fossils, such as Denticula hustedtii and Actinocyclus ingens, do occur in trace abundance throughout this core. Core 1
SITE 322

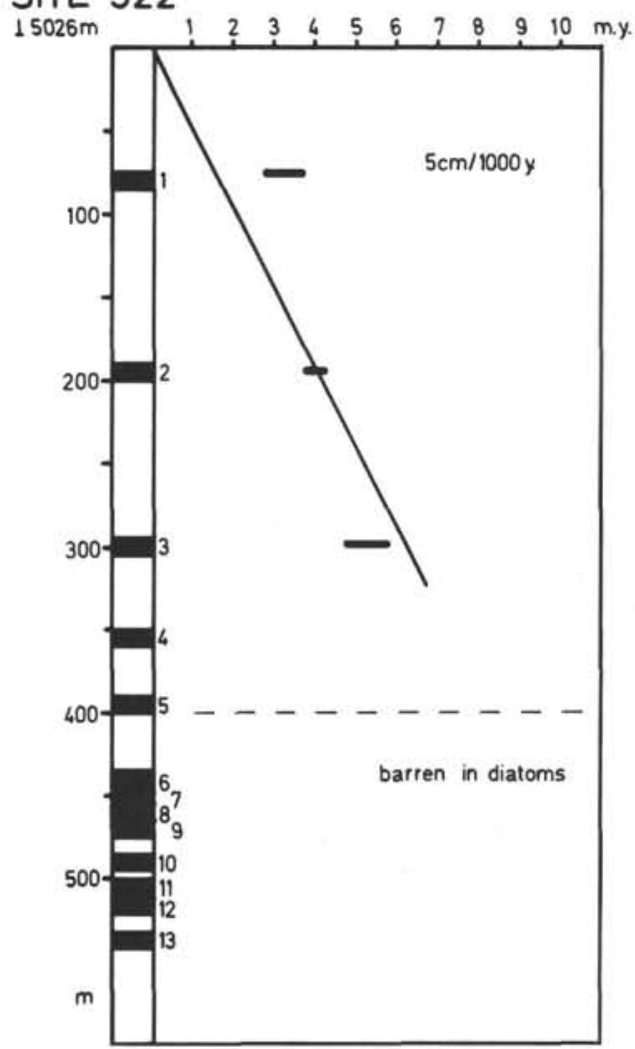

Figure 4. Sediment accumulation rate at Site 322. 
TABLE 5

Samples Barren of Diatoms at Site 323

\begin{tabular}{lll}
\hline $11, \mathrm{CC}$ & $15-1,46-47$ & $16-3,49-50$ \\
$12-1,131-132$ & $15-2,57-58$ & $16-3,87-88$ \\
$12-2,72-73$ & $15-3,51-52$ & $16-4,22-23^{\mathrm{a}}$ \\
$12, \mathrm{CC}$ & $15-3,124-125$ & $16-4,60-61$ \\
$13-1,110-111$ & $15-4,26-27$ & $16-4,133-134$ \\
$13-3,114$ & $15-5,114-115$ & $16, \mathrm{CC}$ \\
$13-5,47-48$ & $15-6,135-136$ & $17-1,16-17$ \\
$13-6,49-50$ & $15, \mathrm{CC}$ & $17-1,85-86$ \\
$13, \mathrm{CC}$ & $16-1,19-20$ & $17, \mathrm{CC}$ \\
$14-1,100-101$ & $16-1,26-27$ & $18-2,141-142$ \\
$14-2,70-71$ & $16-2,11-12$ & $18-3,63-64$ \\
$14-2,134-135$ & $16-2,140-141$ & $18-4,17-18$ \\
$14, \mathrm{CC}$ & $16-3,15-16$ & $18-4,67-68$ \\
\hline \multicolumn{2}{c}{ arace occurrence of diatoms } & displaced by \\
\multicolumn{2}{c}{ coring procedure. }
\end{tabular}

down to 14 meters is, therefore, dated as younger than .35 m.y., using the upper boundary of Donahue's (1970a) Rouxia californica Partial Range Zone.

Core 1, Section $4,66 \mathrm{~cm}$ to Section $5,69 \mathrm{~cm}$ is correlated with the Rouxia californica Partial-Range Zone of Donahue (1970a) and is .35-.66 m.y. in age on the basis of a rare occurrence of Rouxia californica.

Core $1-5,103 \mathrm{~cm}$ through Core $4-2,66 \mathrm{~cm}$ is placed in the Actinocyclus ingens Partial-Range Zone of Donahue (1970a) which has an upper boundary age of .66 m.y. and is characterized by the occurrence of Actinocyclus ingens and in the Coscinodiscus elliptipora/Actinocyclus ingens Concurrent Range Zone of McCollum (1975) which has been dated by paleomagnetic stratigraphic correlation to the radiometric time scale as .7 to 1.6 m.y. in age.

All samples below Core 4 are almost barren in diatoms except 9, CC which does contain a moderately preserved diatom assemblage of low species diversity.

Denticula hustedtii and Trinacria excavata are interpreted as being reworked because Cosmiodiscus insignis and Nitzschia kerguelensis are still present. This sample is placed in the Cosmiodiscus insignis Partial-Range Zone of McCollum (1975) and is correlative to the upper part of the Gauss Normal Epoch and is approximately 2.43 to 2.82 m.y. in age.

Estimates of the percent abundance of Eucampia balaustium versus all other diatom frustules did reveal an increase of Eucampia balaustium in Core 1 (Table 9) and Core 4. Recent Eucampia balaustium is found in highest abundance close to the Antarctic ice sheet and may serve, along with ice-rafted detritus, to reconstruct the extensions and limitations of the ice sheet through time.

The sequence penetrated may comprise an uninterrupted section representing most of the upper Pliocene and Quaternary. However, due to discontinuous coring

\section{SITE 323}

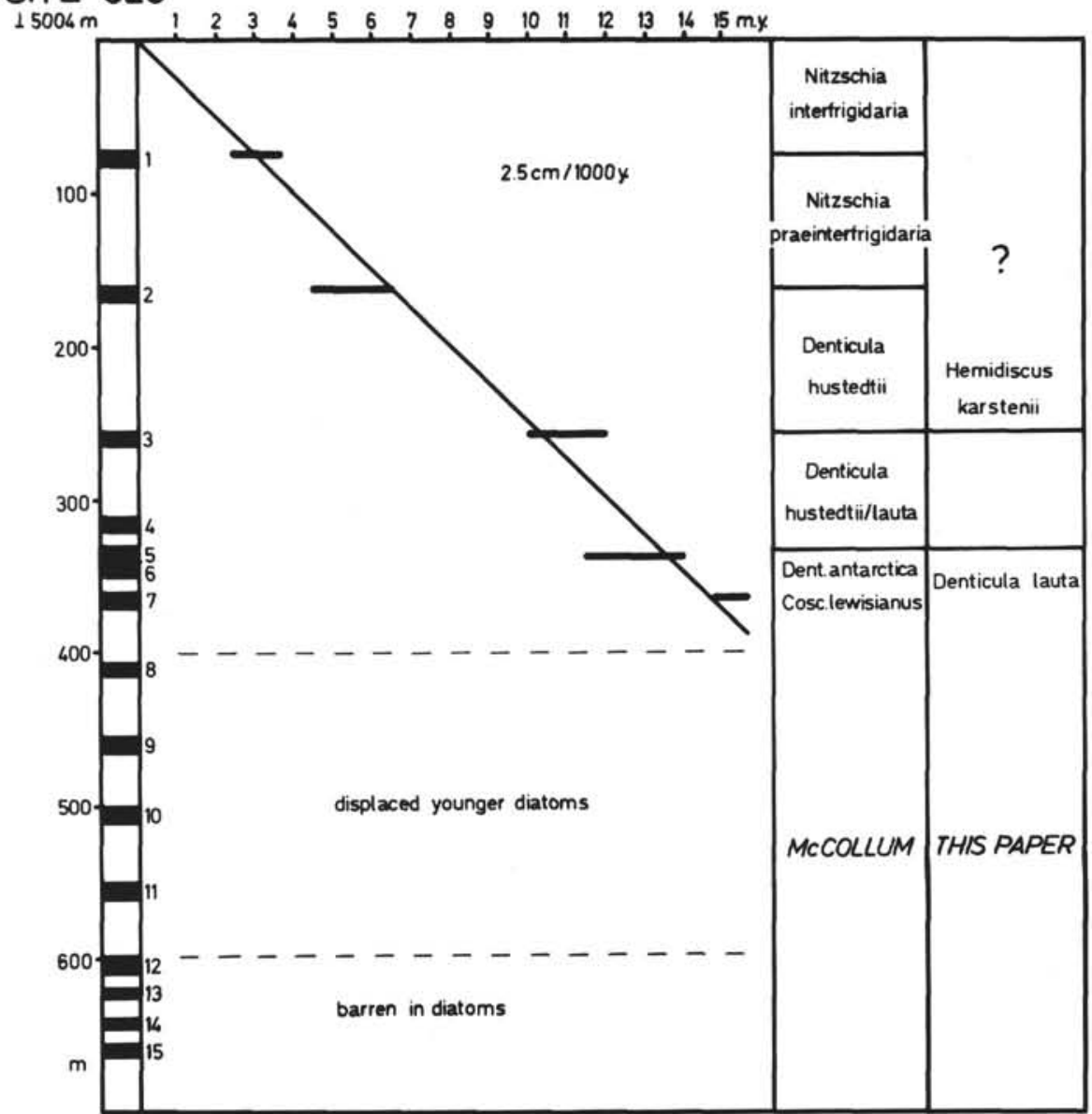

Figure 5. Sediment accumulation rate and biostratigraphic zonation at Site 323. 
TABLE 6

Distribution of Diatoms at Site 323

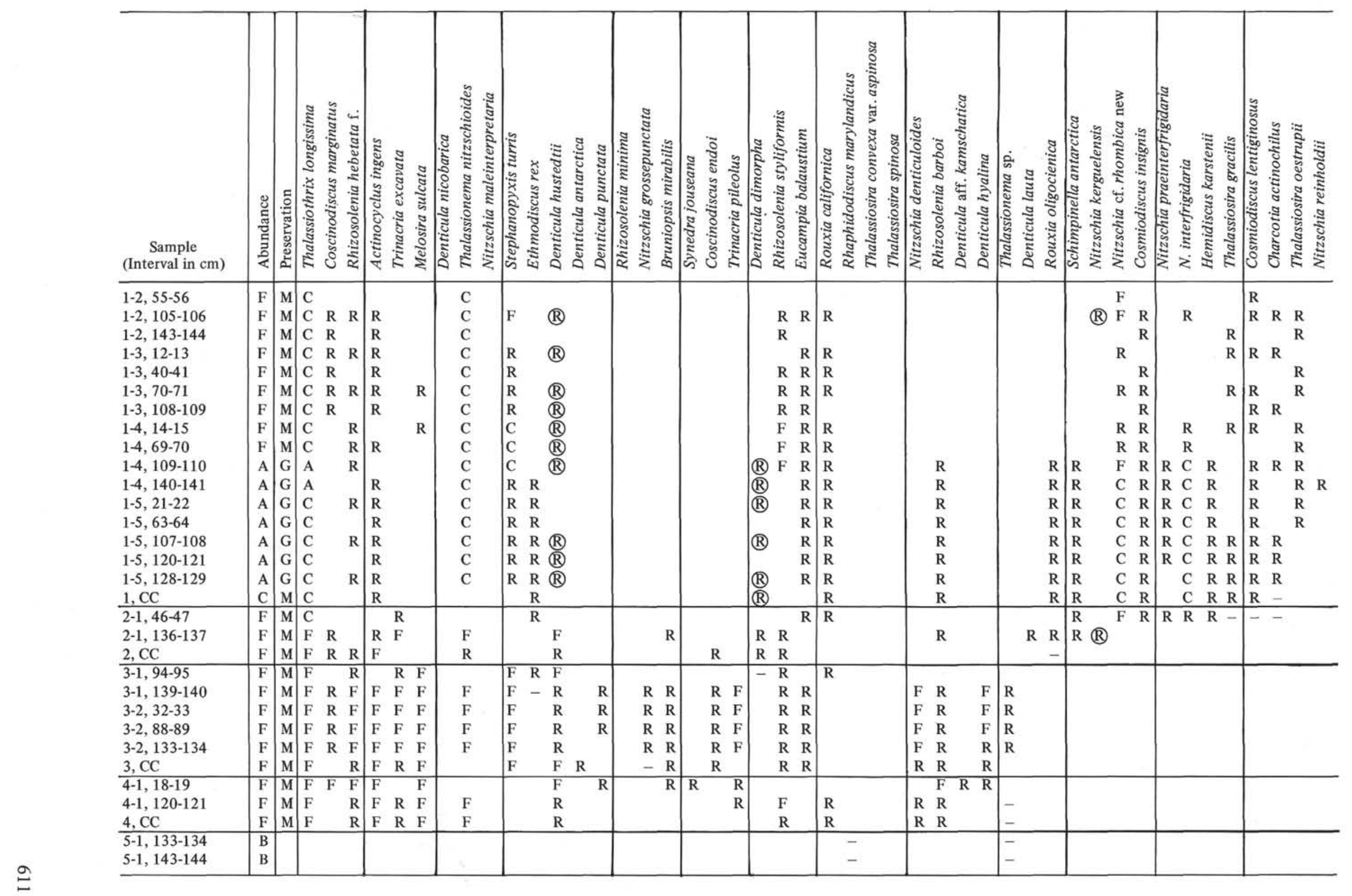

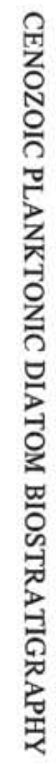


TABLE 6 - Continued

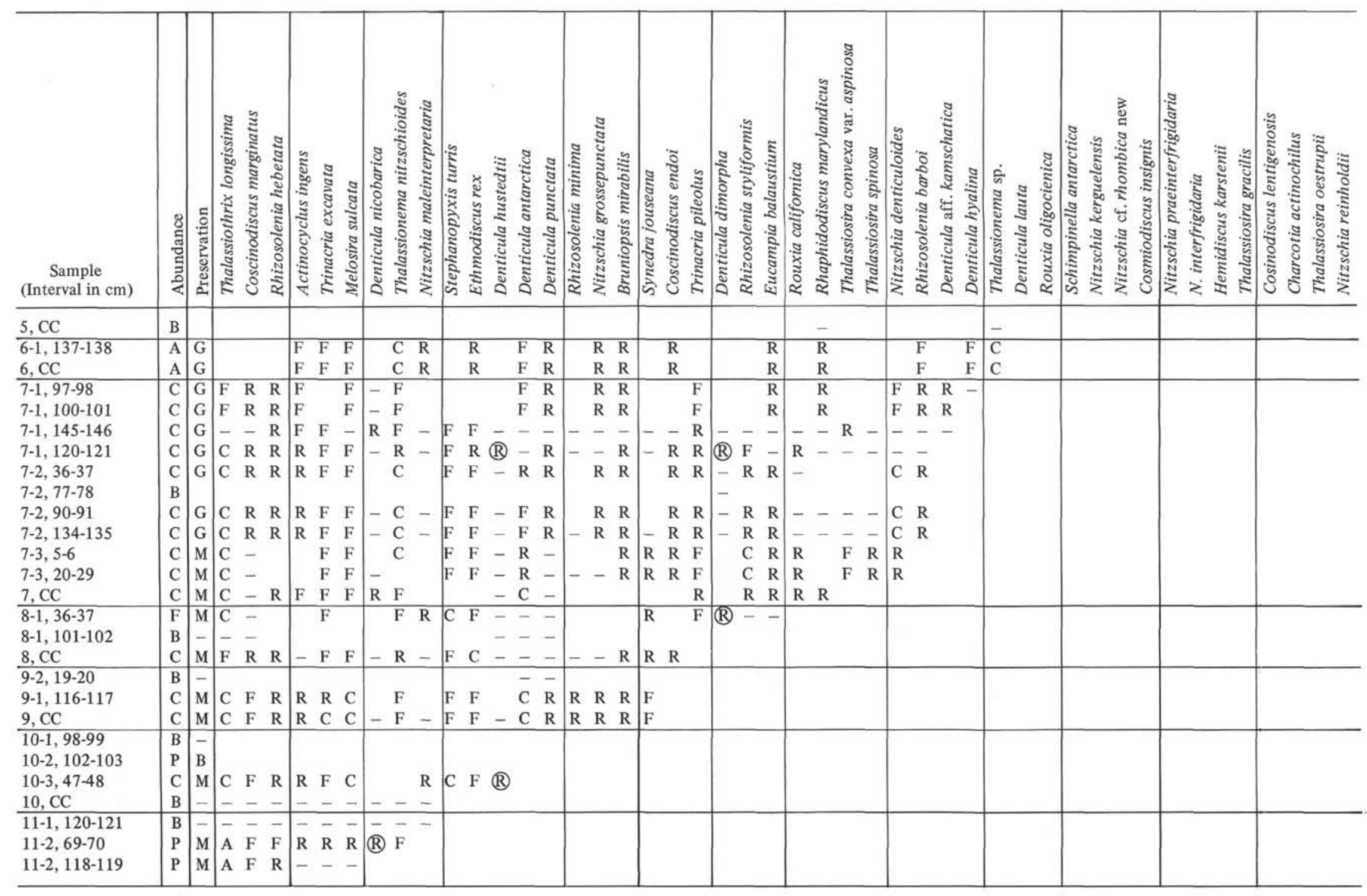


TABLE 7

Distribution of Diatoms at Site 324

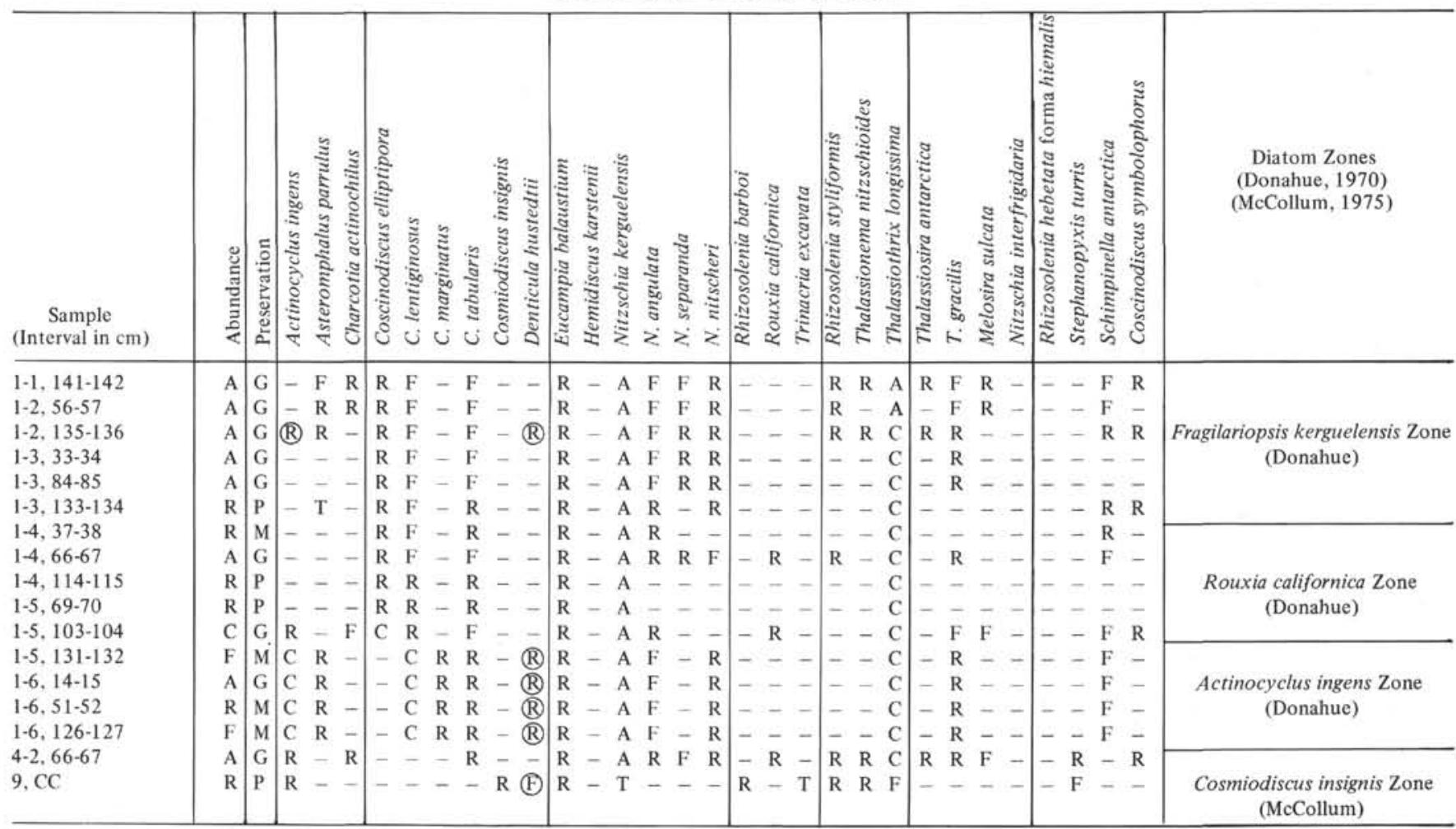

Note: $\mathrm{O}=$ reworked, $\mathrm{T}=$ trace, $\mathrm{R}=$ rare, $\mathrm{F}=$ few, $\mathrm{C}=$ common, $\mathrm{A}=$ abundant.

TABLE 8

Samples Barren of Diatoms at Site 324

\begin{tabular}{llll}
\hline $1, \mathrm{CC}$ & $3-2,22-23$ & $4-4,55-56$ & $7-1,81-82$ \\
$2-1,15-16$ & $3-2,109-110$ & $4, \mathrm{CC}$ & $7-2,117-118$ \\
$2-1,76-77$ & $3-3,48-49$ & $5-1,95-96$ & $7-3,132-133$ \\
$2-2,73-74$ & $3-3,113-114$ & $5-1,130-131$ & $7-4,143-144$ \\
$2-2,144-145$ & $3-4,43-44$ & $5-2,93-94$ & $7-6,144-145$ \\
$2-3,73-74$ & $3-4,118-119$ & $5-2,125-126$ & $7, \mathrm{CC}$ \\
$2-3,115-116$ & $3-5,84-85$ & $5-3,41-42$ & $8-2,132-133$ \\
$2-4,75-76$ & $3-6,117-118$ & $5-3,92-93$ & $8-3,21-22$ \\
$2-5,71-72$ & $3, \mathrm{CC}$ & $5, \mathrm{CC}$ & $8, \mathrm{CC}$ \\
$2-6,110-111$ & $4-2,20-21$ & $6-1,98-99$ & $9-1,120-121$ \\
$2, \mathrm{CC}$ & $4-2,141-142$ & $6-2,32-33$ & \\
$3-1,22-23$ & $4-3,48-49$ & $6-6,131-132$ & \\
$3-1,100-101$ & $4-3,106-107$ & $6, \mathrm{CC}$ & \\
\hline
\end{tabular}

this theory cannot be confirmed and correlation with other Quaternary climate curves is not possible at the present time (Figure 6).

Sediment accumulation rates cannot be effectively determined for this site. All that can be postulated from tentative diatom stratigraphic subdivision is an average sediment accumulation of $7.5 \mathrm{~cm} / 1000 \mathrm{yr}$ (Figure 7).

\section{Site 325}

Site 325 is located on the upper continental rise northwest of the Antarctic Peninsula, about 80 miles from the base of the continental slope. The sedimentary sequence consists of terrigenous detritus except for a few thin beds with mainly biogenic components. The two lithologic units consist of about 570
TABLE 9

Occurrence (in percent) of Eucampia balaustium at Site 324

\begin{tabular}{lccc}
\hline $\begin{array}{c}\text { Sample } \\
\text { (Interval in cm) }\end{array}$ & $\begin{array}{c}\text { Total } \\
\text { Count }\end{array}$ & $\begin{array}{c}\text { E. balaustium } \\
(\%)\end{array}$ & $\begin{array}{c}\text { Other } \\
\text { Diatoms } \\
(\%)\end{array}$ \\
\hline $1-1,141-142$ & 167 & 11.9 & 88.1 \\
$1-2,56-57$ & 210 & 6.2 & 93.8 \\
$1-2,135-136$ & 214 & 3.7 & 96.3 \\
$1-3,33-34$ & 227 & 4.8 & 95.2 \\
$1-3,84-85$ & 219 & 5.0 & 95.0 \\
$1-4,66-67$ & 215 & 2.3 & 97.7 \\
$1-4,114-115$ & 38 & 18.4 & 81.6 \\
$1-5,103-104$ & 201 & 10.8 & 89.2 \\
$1-6,14-15$ & 210 & 8.4 & 91.6 \\
$1-6,126-127$ & 121 & 13.2 & 86.8 \\
$4-1,139-140$ & 41 & 43.9 & 56.1 \\
$4-2,66-67$ & 292 & 7.2 & 92.8 \\
\hline
\end{tabular}

meters of clay and claystone (Unit 1) overlying 148 meters of dominantly coarser clastic rocks with minor claystone.

Diatoms occur in each core, those in Cores 1 through 6 comprise a low diversity Antarctic assemblage with moderate to poorly preserved frustules; those in Cores 7-10 are pyritized and consequently an age determination was not possible. Samples without diatoms or with recrystallized tests are listed in Table 10.

Core 1 , Sections 2 and 3 contained only a poorly preserved assemblage. Age-diagnostic fossils occurred only rarely. The first occurrence of Nitzschia kerguelensis places this sample into the upper part of the 


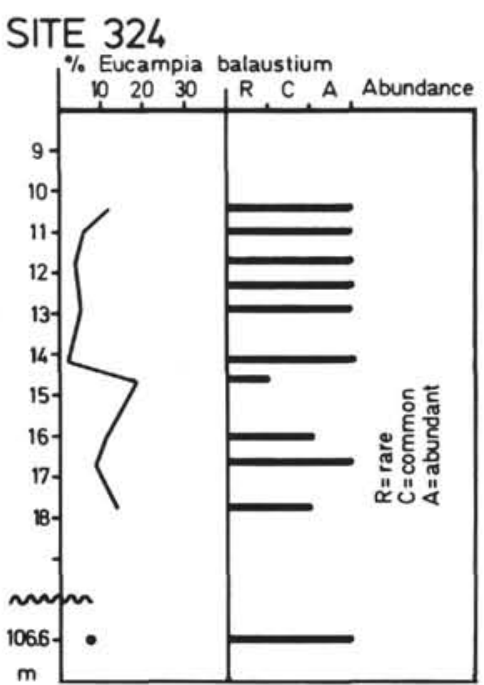

Figure 6. Percent occurrence of Eucampia balaustium in selected samples from Site 324.

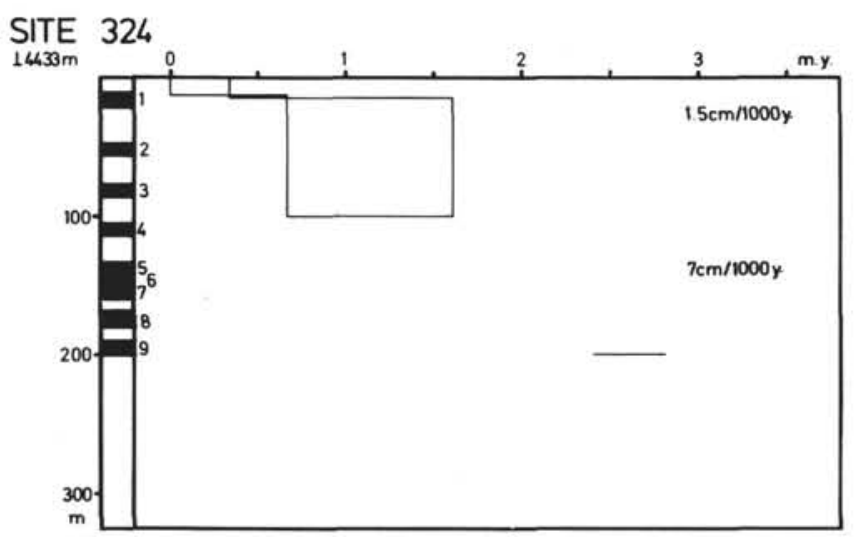

Figure 7. Sediment accumulation rate at Site 324 .

TABLE 10

Samples Barren of Age Diagnostic

Diatoms at Site 325

\begin{tabular}{lll}
\hline $1-4,94-96$ & $8-2,120-121$ & $9-3,2-4^{\mathrm{b}}$ \\
$5-1,104-105$ & $8-3,120-121$ & $9-3,49-53$ \\
$6-1,42-43$ & $8-3,121-122$ & $9-3,84-85$ \\
$7-1,104-105$ & $8, \mathrm{CC}$ & $9-3,135-136^{\mathrm{b}}$ \\
$7-2,22-24$ & $9-1,134-135$ & $9, \mathrm{CC}^{\mathrm{b}}$ \\
$7, \mathrm{CC}$ & $9-2,6-8$ & $10-1,88-89$ \\
$8-1,56-57$ & $9-2,83-85^{\mathrm{b}}$ & $10-2,92-93$ \\
$8-1,116-117$ & $9-2,107-110$ & $10-3,55-56$ \\
$8-2,52-52^{\mathrm{a}}$ & $9-2,130-133$ & $10, \mathrm{CC}$ \\
\hline
\end{tabular}

Pliocene with an age of younger than 2.43 m.y.B.P. Core 1, Section 4, $140 \mathrm{~cm}$ through Core 3, Section 4, $104 \mathrm{~cm}$ contained Nitzschia interfrigidaria and Cosmiodiscus insignis, which are characteristic fossils of the Nitzschia interfrigidaria Partial-Range Zone of McCollum (1975) which has been correlated with an upper boundary near the Kaena Event (2.85 m.y.B.P.) and the base above the "A" event within the Gilbert Reverse Magnetic Epoch (3.65 m.y.B.P.). Sample 3, CC is tentatively placed within the Nitzschia praeinter- frigidaria Partial-Range Zone of McCollum (1975), and has been correlated to paleomagnetic stratigraphy with the base at the "C" event of the Gilbert epoch (approximately 4.5 m.y.B.P.) and the top near the " $A$ " event of the Gilbert Epoch (3.65 m.y.B.P.). Samples below this level are placed within the Miocene. Poorly preserved material does not allow detailed zonation to be determined (Table 11). Sedimentation rates can only be roughly calculated at $6.6 \mathrm{~cm} / 1000 \mathrm{yr}$ for the Quaternary/Pliocene interval (Figure 8).

\section{REWORKING}

The three important water masses in the Antarctic are the Antarctic Bottom Water (ABW), the Circumpolar Deep Water (CPDW), and the Antarctic Surface Water (ASW). The Antarctic Bottom Water is the main source of erosion, transport, and reworking of older microfossils into younger strata. ABW is composed of three major water types (Gordon, 1971a), the first is made up of the bottom layer of the Circumpolar Deep Water, the second is a cold, relatively fresh $\left(34.66^{\circ} / 00 \mathrm{~S}\right)$ variety and is formed in shelf areas such as the Weddell Sea and Ross Sea. The third is a cold highly saline $\left(34.75^{\circ} \%\right.$ o S) variety (Gordon, 1971b).

All three types spread clockwise between Antarctica and the mid-ocean ridge. These currents transport components as far north into the Pacific and Atlantic as the equator (Burckle, 1974). There is good correlation of sediment types found in the Antarctic due to primary/secondary production and to circulation of the overlying water masses (Lisitzin, 1960). The southern section of the Southern Ocean is covered with ice-rafted terrigenous sediments which are predominantly silty sands. The northern limit of glacial marine sediments corresponds to the northern limit of the pack ice and varies in width from 300 to $900 \mathrm{~km}$ (Conolly and Ewing, 1965). Diatom ooze underlies the area of high primary production. North of the Antarctic Polar Front, the high production of foraminifera results in deposition of foraminiferal ooze (Figure 9). The transport mechanism of the Antarctic Bottom Water is responsible for the fact that several extinct species of diatoms have been found in Antarctic sediment surface samples such as Rouxia antarctica, Denticula species which became extinct in late Miocene through early Pliocene time. The same type of reworking is responsible for the occurrence of Miocene species in Pleistocene sediments, which are the basis for a diatom biostratigraphic subdivision of the Pleistocene (partly Donahue, 1970a and Abbott, 1972, in press). Rouxia oligocenica, Hemidiscus karstenii, Rouxia antarctica, Rouxia peragalli, Rouxia peragalli forma yabei are all abundant in Antarctic Pleistocene sediments, thus the plotted ranges of these species (Abbott, 1972, in press) do not represent actual ranges or extinctions (Figure 10). These "ranges" are local occurrences and cannot be used in other areas. On the other hand, the occurrence of reworked species is limited in the materials drilled during Leg 35 , and this may lead to the conclusion that eroded material is redeposited by the ABW before entering this area and erosion must have taken place in other areas. 
TABLE 11

Distribution of Diatoms at Site 325

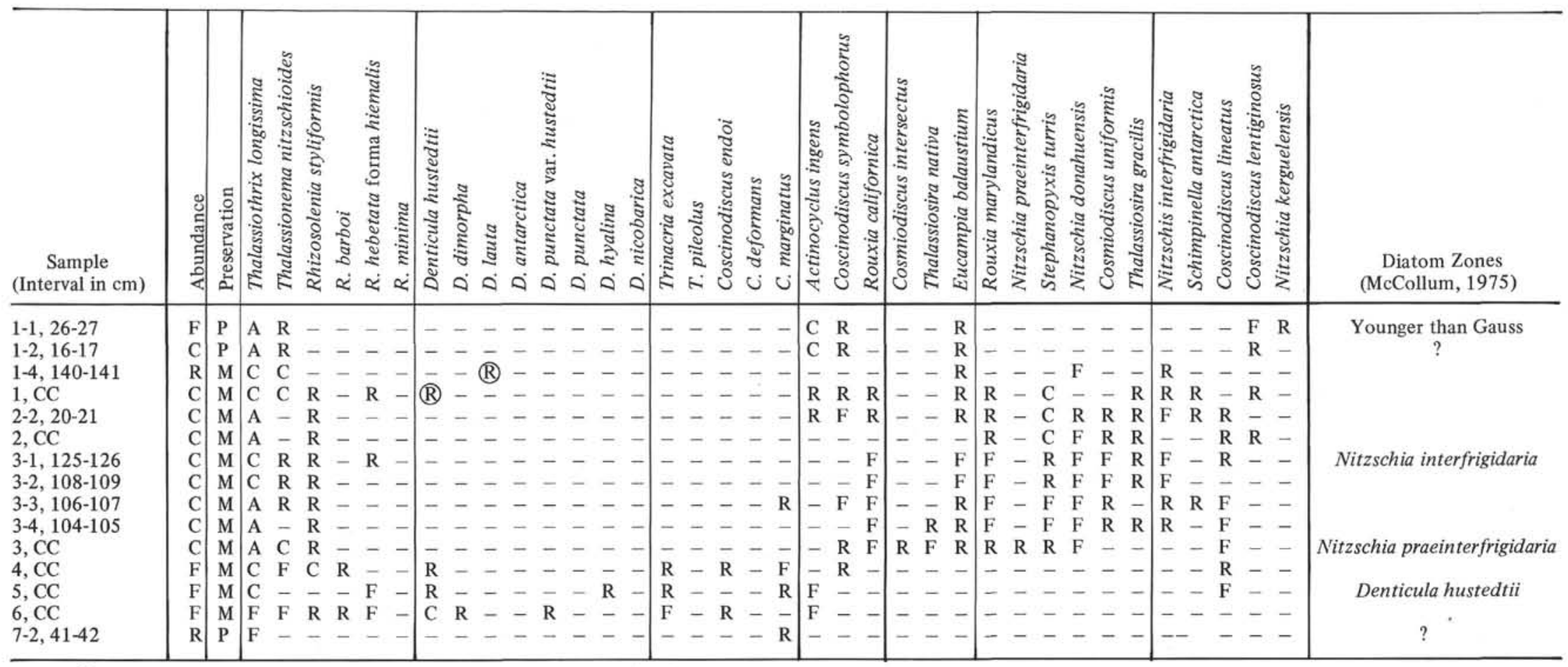

Note: $\mathrm{O}=$ reworked, $\mathrm{T}=$ trace, $\mathrm{R}=$ rare, $\mathrm{F}=$ few, $\mathrm{C}=$ common, $\mathrm{A}=$ abundant. 


\section{SITE 325}

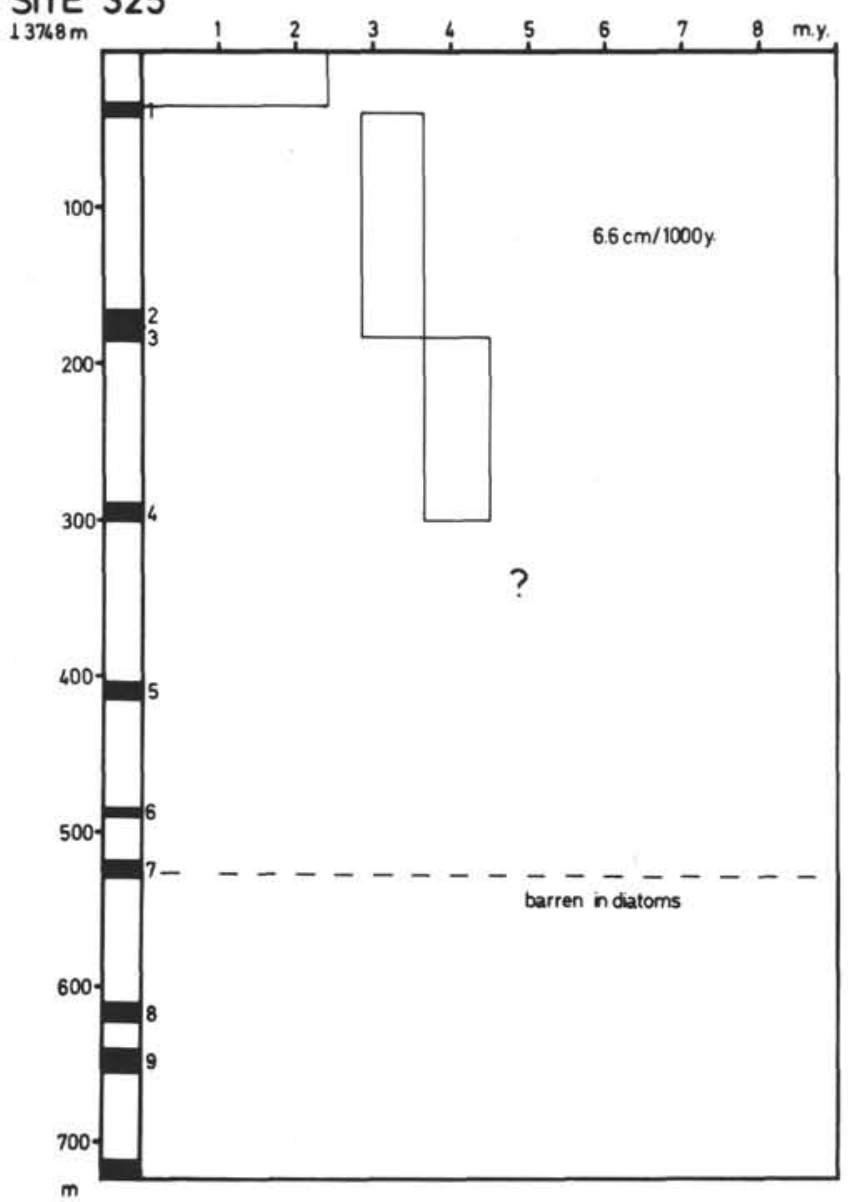

Figure 8. Sediment accumulation rate at Site 325.

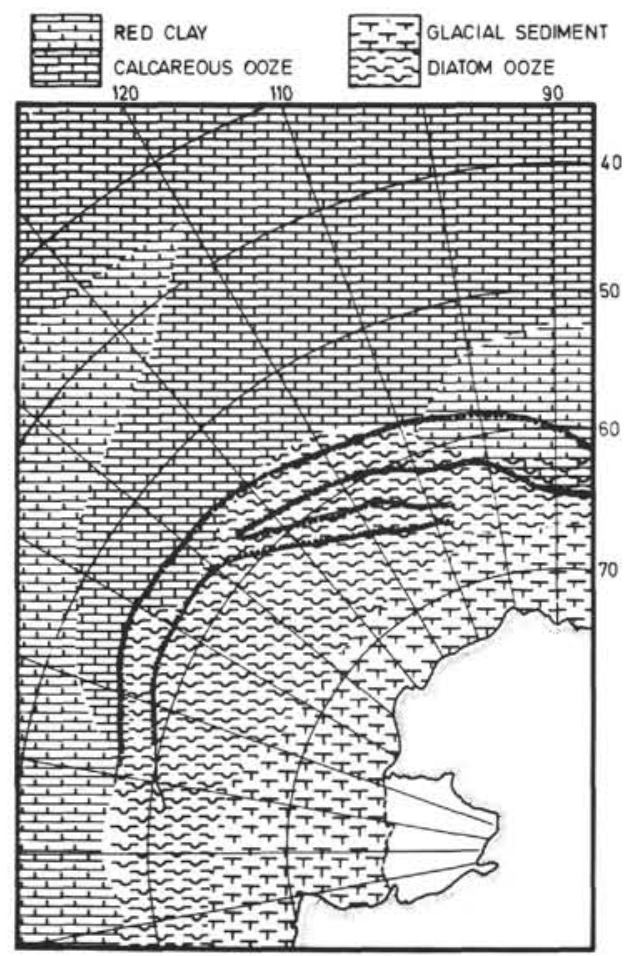

Figure 9. Sediment distribution in the Antarctic after Goodell et al., 1965.

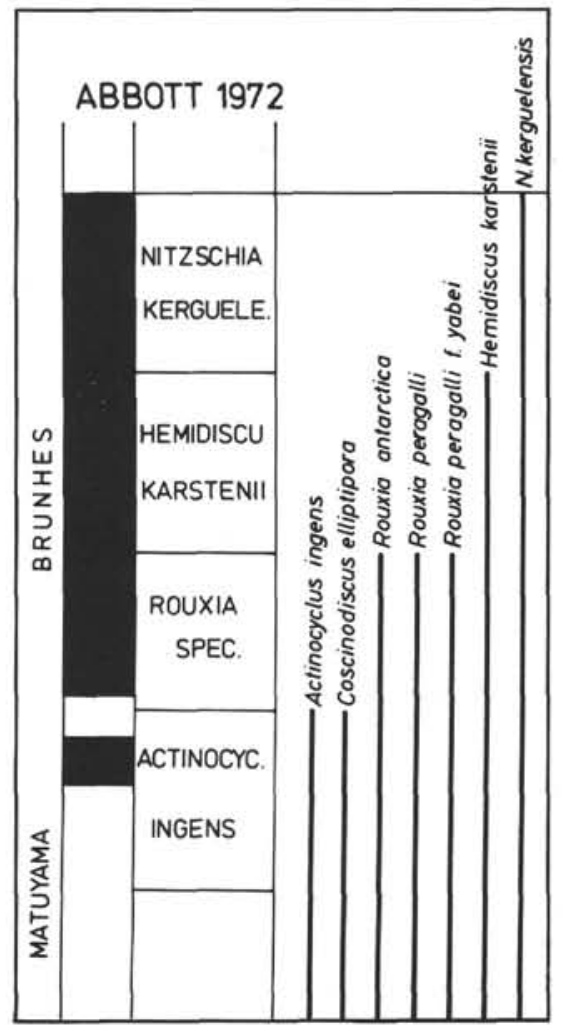

Figure 10. "Ranges" (as a result of reworking of Miocene species) of selected diatoms and diatom biostratigraphic zonation of Abbott (1972, in press).

\section{EPOCH AND AGE BOUNDARIES}

\section{Introduction}

During the past 5 years considerable progress has been made in defining absolute dates for epoch and age boundaries and in relating these data to the type European standards. Paleomagnetics have played a considerable role in this progress, but refinements in geochemical dating techniques, increased use of micropaleontological datum levels, and the effort of several workers to synthesize these data on a worldwide scale (Berggren, 1969, 1972) have also been important. These advances permit us to discuss, with some confidence, the placement of Neogene epoch and age boundaries and their relationship to the paleomagnetic stratigraphy.

\section{Paleomagnetic Stratigraphy}

In the past 10 years, paleomagnetics have become an important ancillary tool to the micropaleontologist (Opdyke et al., 1966; Burckle, 1972). Foster and Opdyke (1970) extended the paleomagnetic reversal record back to Epoch 11 (middle/late Miocene boundary) and Opdyke et al. (1970) and Opdyke (1972) found reversals back to Magnetic Epoch 15. In 1974 Opdyke et al. and Theyer and Hammond reported on new findings and extended the reversal record back to Magnetic Epoch 19. 


\section{Early/Middle Miocene Boundary}

The early/middle Miocene boundary is placed at the first appearance of the genus Orbulina (Orbulina datum). Berggren (personal communication) and Opdyke et al. (1974) are in agreement that this boundary is placed at about 15 m.y.B.P. By studying calcareoussiliceous sediments from DSDP Leg 9 Opdyke et al. (1974) determined that the Orbulina datum occurs just after the first appearance of the diatom Annellus californicus. In noncalcareous cores studied by Burckle (Schrader and Burckle, in preparation) (RC13-22 and 24) the first appearance of Annellus californicus occurs in the upper part of Magnetic Epoch 16 and the last occurrence is in the lower part of Epoch 15. In DSDP Leg 9 material the Orbulina datum is approximately halfway between the first and last appearance of $A$. californicus. For this reason, Opdyke et al. (1974) have contended that the early/middle Miocene boundary must occur on or near the boundary of Magnetic Epochs 16 and 15. It is interesting that Theyer and Hammond (1974), using radiolarians, have come to much the same conclusion.

\section{Middle/Upper Miocene Boundary}

Burckle (1972) correlated the middle/upper Miocene boundary to the lower part of Magnetic Epoch 11 .

\section{Miocene/Pliocene Boundary}

Saito (1969) was the first to correlate the Miocene/Pliocene transition with the top of Magnetic Epoch 5. This conclusion has been largely substantiated by Berggren (1972).

\section{Pliocene/Pleistocene Boundary}

The Pliocene/Pleistocene boundary problem has been reviewed by a number of workers (Hays and Berggren, 1971; Cita, 1972; Burckle, 1972). Most workers are in general agreement that this transition occurred during the Olduvai Event of the Matuyama Reversed Epoch.

Placement of stage boundaries discussed in this report with respect to magnetic stratigraphy may be summarized as follows: (1) The early middle Miocene boundary occurs at or near the boundary of Magnetic Epochs 16 and 15. (2) The middle/late Miocene boundary occurs in Magnetic Epoch 11. (3) The Miocene/Pliocene boundary occurs at the end of Magnetic Epoch 5. (4) The Pliocene/Pleistocene boundary occurs during the Olduvai Event of the Matuyama Reversed Epoch. Placement of late Cenozoic epochal and stage boundaries with respect to Southern Ocean diatom biostratigraphic subdivision is summarized as follows:

1) The Oligocene/early Miocene boundary occurs at the top of the Pyxilla prolungata Zone of McCollum (1975) and at the top of the Pyxilla species Zone as defined in this paper.

2) The early Miocene/middle Miocene boundary occurs at the base of the Denticula nicobarica Zone of McCollum (1975), which differs from results obtained in this study. Placement of this boundary has here been made between the Coscinodiscus lewisianus Zone (lower part) and the Denticula lauta Zone. This corresponds to the placement of this boundary, as defined for the North Pacific (Schrader, 1973a).
3) The middle Miocene/late Miocene boundary occurs at the base of the Denticula hustedtii/Denticula lauta Zone of McCollum (1975) or between the Coscinodiscus yabei Zone (lower part) and the Denticula dimorpha Zone (upper part) as defined in this paper.

4) The late Miocene/Pliocene boundary occurs in the Denticula hustedtii Zone of McCollum (1975) and has not yet been precisely defined.

5) The Pliocene/Pleistocene boundary occurs within the Rhizosolenia barboi/Nitzschia kerguelensis Zone of McCollum (1975).

\section{TIME RANGES OF TAXA AND BIOSTRATIGRAPHIC ZONATION}

Planktonic marine diatom zonations for the late Quaternary of the Southern Ocean were first established by Donahue (1970a) on sediment cores of the Bellingshausen Sea (Figure 11). A similar study by Abbott (1972, in press) using sediment cores of the Southern Indian and South Pacific oceans included only the latest Quaternary (Brunhes). McCollum discussed and established a diatom biostratigraphic zonation for the Oligocene to Recent on material obtained predominantly from the Ross Sea during Deep Sea Drilling Project Leg 28. McCollum's zonation from the Recent to the Miocene/Pliocene boundary has been correlated to paleomagnetic stratigraphy and was used unchanged in this report (Figure 12). Conversely, the Miocene to Oligocene interval (Figure 13) has been restudied using DSDP Site 278 sediment material and differs in the ranges of a few key species from that pro-

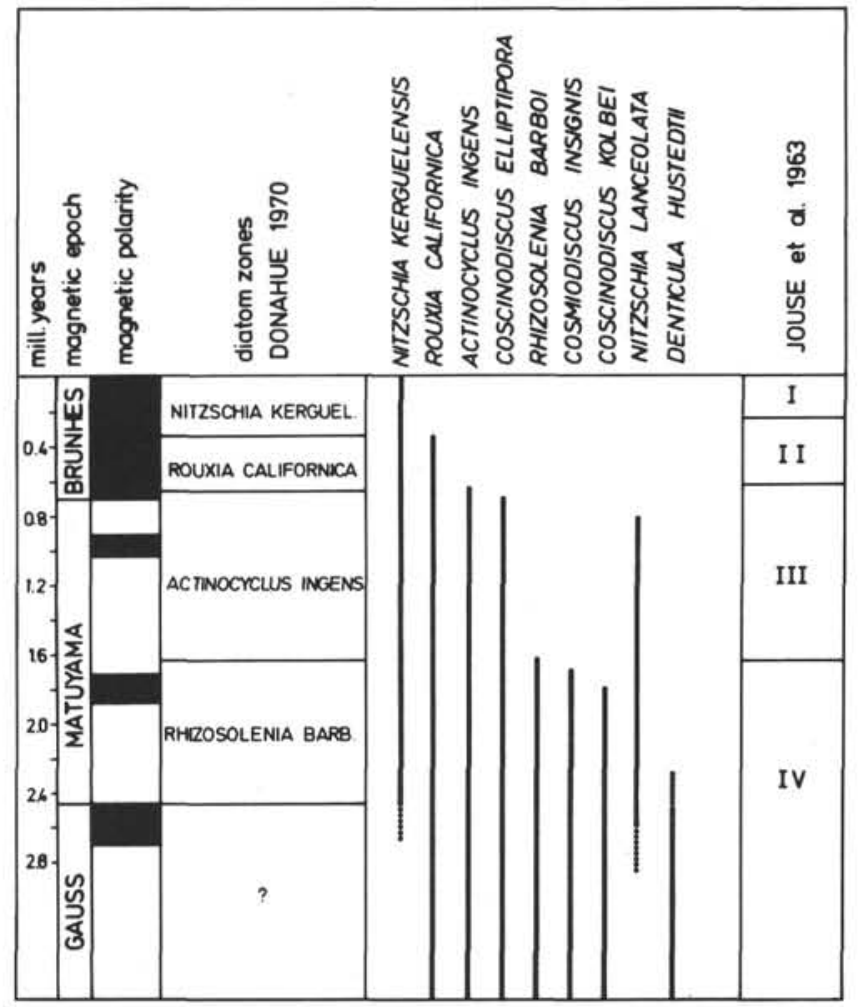

Figure 11. Ranges of selected diatom species and diatom biostratigraphic zonation of Donahue (1970a) with correlation to paleomagnetic stratigraphy and diatom zonation of Jouse et al. (1963). 


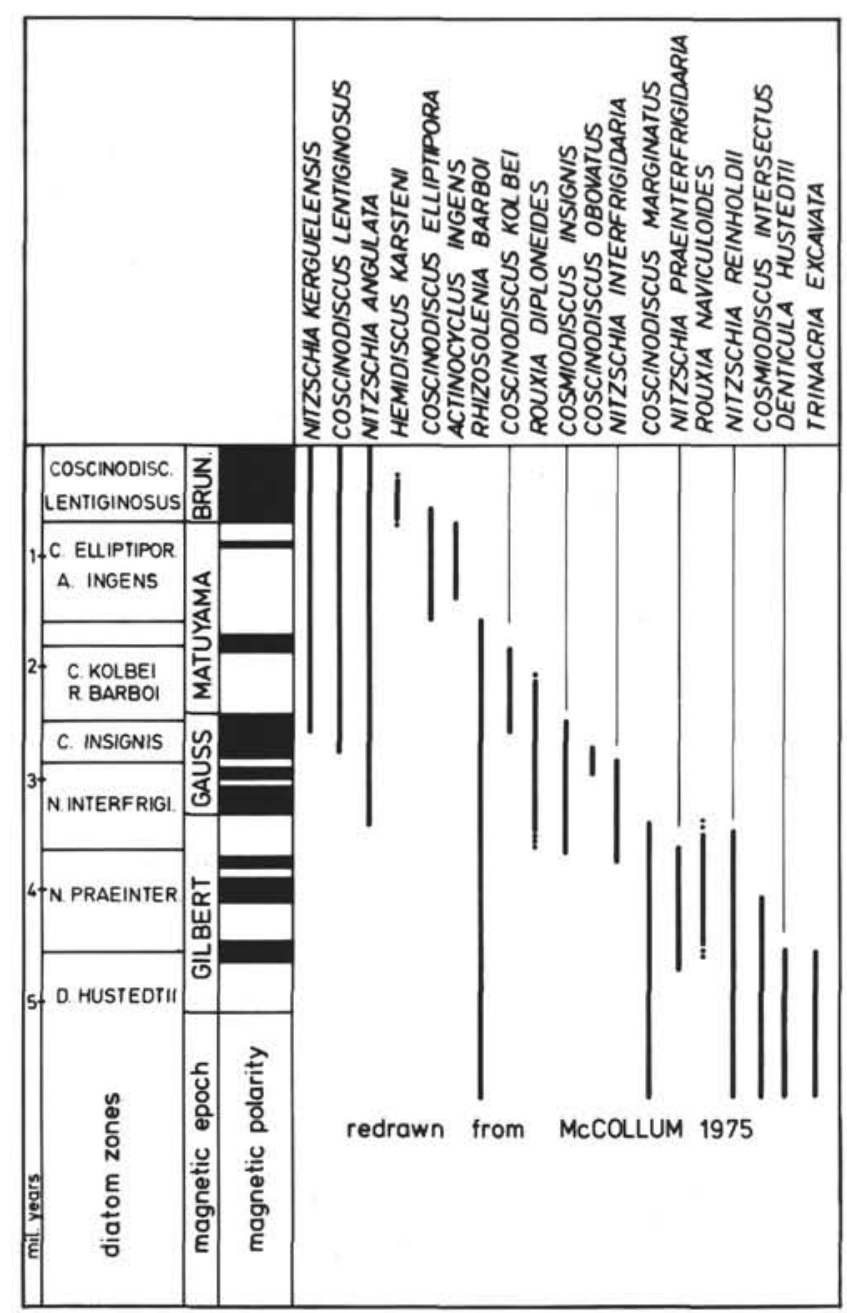

Figure 12. Ranges of selected diatom species and diatom biostratigraphic subdivision of McCollum (1975) with correlation to the Quaternary/Pliocene paleomagnetic stratigraphy as used in this paper.

posed by McCollum. This new zonation, which basically uses known Denticula species, has been used in this report for biostratigraphic interpretation of the Miocene through Oligocene interval (Figure 14) (Table 12).

Zonations with higher biostratigraphic resolution but with a similar floral content were presented by Burckle $(1969,1972)$ for the equatorial east Pacific, by Jousé (1971) for the northeast Pacific, by Koizumi (1973) for the northwest Pacific, by Kanaya and Koizumi (1970) for the circum-Pacific region, by Schrader and Burckle (in preparation) for the tropical Pacific, by Jousé (1974) for the tropical belt of oceans, by Schrader for the northwest Pacific (1973a) and for the tropical Indian Ocean (1974). Cross-correlations were made whenever possible. It seems that at present a standard diatom stratigraphy is still not possible, because of local ranges of high diversities, high ecological variation, and paleogeographical distribution.

The principles designated by Riedel and Sanfilippo (1970) for establishing zones were used in this study.
The following diatom zones are defined as local range zones in accordance with the Code of Stratigraphic Nomenclature (1961).

Unless otherwise stated, subzones, paleomagnetic stratigraphy, and absolute ages have not yet been determined for the following zones.

\section{Hemidiscus karstenii Partial-Range Zone}

Definition: The base of this zone has been defined by the last occurrence of Coscinodiscus yabei, the top by the last occurrence of Rhizosolenia minima.

Discussion: Other floral elements include $A C$ tinocyclus ingens, Bruniopsis mirabilis, Coscinodiscus deformans, C. endoi, C. marginatus, $C$. intersectus, Denticula dimorpha, $D$. hustedtii, $D$. hustedtii var. ovata (first occurrence in the upper part of this zone), D. lauta (last occurrence in the lower part of this zone), Denticula aff. seminae, Ethmodiscus rex, Eucampia balaustium, Hemidiscus karstenii (first occurrence in the lower part of this zone), Mediaria splendida, Nitzschia claviceps, $N$. denticuloides (last occurrence in the upper part of this zone), $N$. donahuensis, $N$. januaria, Rhizosolenia barboi, $R$. hebetata forma hiemalis, $R$. hebetata f. hiemalis spinosa, $R$. styliformis, Rouxia californica, $R$. naviculoides, Stephanopyxis turris, Thalassionema nitzschioides, Thalassiosira nativa (first occurrence in the upper part of this zone), Thalassiothrix longissima, Trinacria excavata.

Comparison with the zonations of other workers: This zone can be correlated with the Denticula hustedtii Zone of McCollum (1975).

Type locality: DSDP Leg 29, Site 278, Samples 11-1, $50-51 \mathrm{~cm}$ to $9-6,50-51 \mathrm{~cm}$.

\section{Coscinodiscus yabei Range Zone}

Definition: The base of this zone has been defined by the first occurrence of Coscinodiscus yabei, and Nitzschia donahuensis, the top by the last occurrence of Coscinodiscus yabei. The zone is defined by the range of Coscinodiscus yabei.

Discussion: Other floral elements include Actinocyclus ingens, Bruniopsis mirabilis, Coscinodiscus deformans, $C$. endoi, $C$. marginatus, C. symbolophorus, $C$. yabei, Cosmiodiscus intersectus, Denticula dimorpha, $D$. hustedtii, D. hustedtii var. ovata, D. aff. kamtschatica, D. lauta, Eucampia balaustium, Mediaria splendida, Melosira sulcata, Nitzschia claviceps, $N$. denticuloides, $N$. donahuensis, $N$. januaria, $N$. porteri, $N$. pseudokerguelensis, Rhizosolenia barboi, $R$. hebetata forma hiemalis, $R$. minima, $R$. styliformis, Rouxia californica, $R$. isopolica, $R$. naviculoides, Stephanopyxis turris, Thalassionema nitzschioides, Thalassiothrix longissima. Nitzschia pseudokerguelensis becomes extinct near the top of this zone; Mediaria splendida first appears near the base of this zone. Both Coscinodiscus yabei and Mediaria splendida have longer ranges in the North Pacific.

Comparison with the zonations of other workers: This zone is correlative to the upper part of the Denticula hustedtii/Denticula lauta Zone of McCollum (1975), and to the Coscinodiscus yabei Zone of Schrader and Burckle (in preparation). 


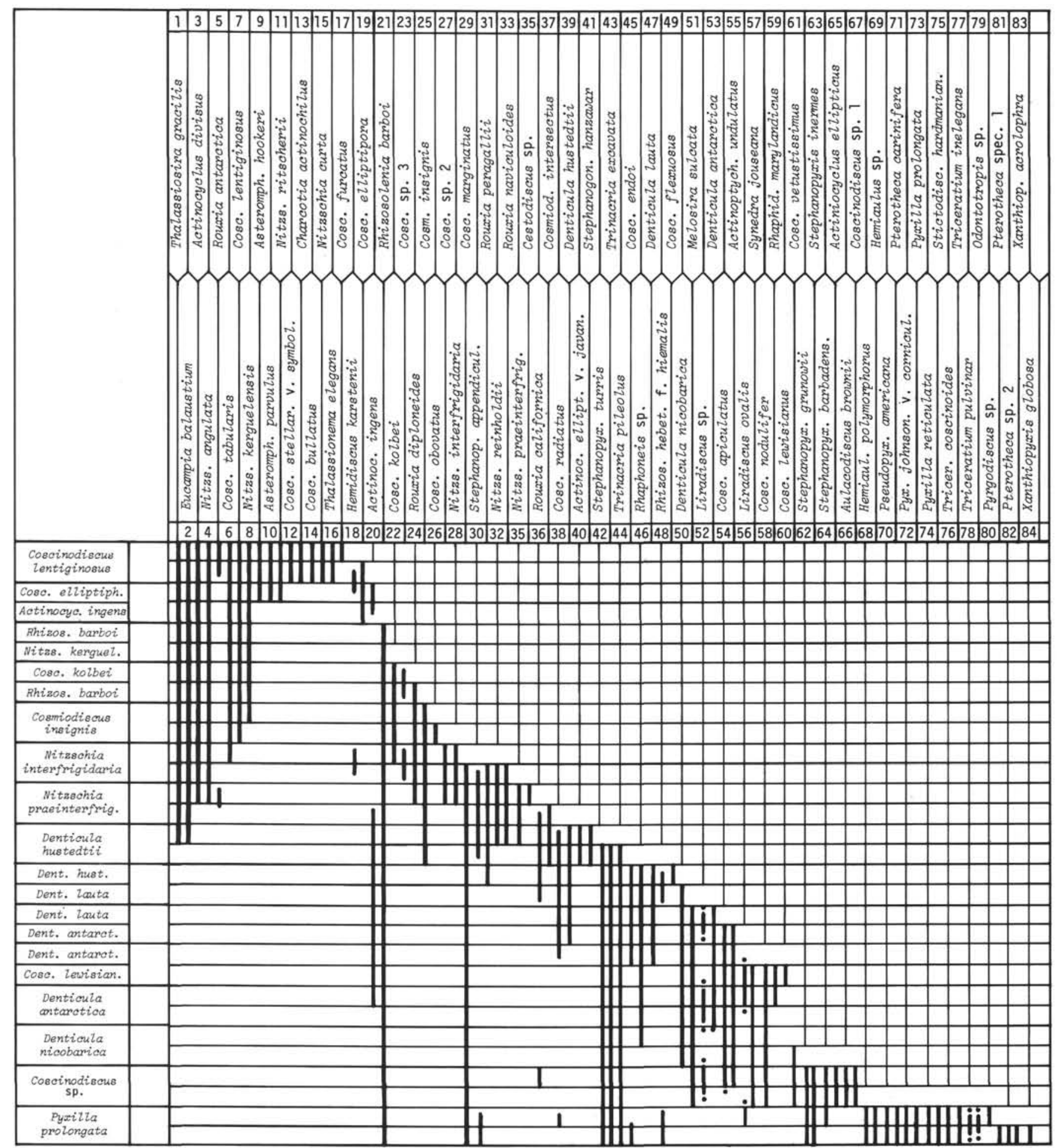

Figure 13. Ranges of selected diatom species for the Oligocene/Miocene interval from McCollum (1975). Species are listed in descending order of their last occurrences.

Type locality: DSDP Leg 29, Site 278, Samples 12-2, $50-51 \mathrm{~cm}$ to $11-2,50-51 \mathrm{~cm}$.

\section{Denticula dimorpha Partial-Range Zone}

Definition: The base of this zone has been defined by the last occurrence of Denticula nicobarica, the top by the first occurrence of Coscinodiscus yabei and Nitzschia donahuensis.
Discussion: Other floral elements include Actinocyclus ingens, Asteromphalus hookeri, Bruniopsis mirabilis, Coscinodiscus deformans, C. endoi, C. marginatus, C. vetustissimus, Denticula aff. antarctica, D. dimorpha, D. aff. kamtschatica, D. lauta, Ethmodiscus rex, Eucampia balaustium, Nitzschia claviceps (first occurrence near the base of this zone), $N$. denticuloides, $N$. pseudokerguelensis, Rhizosolenia alata, $R$. barboi, $R$. hebetata for- 


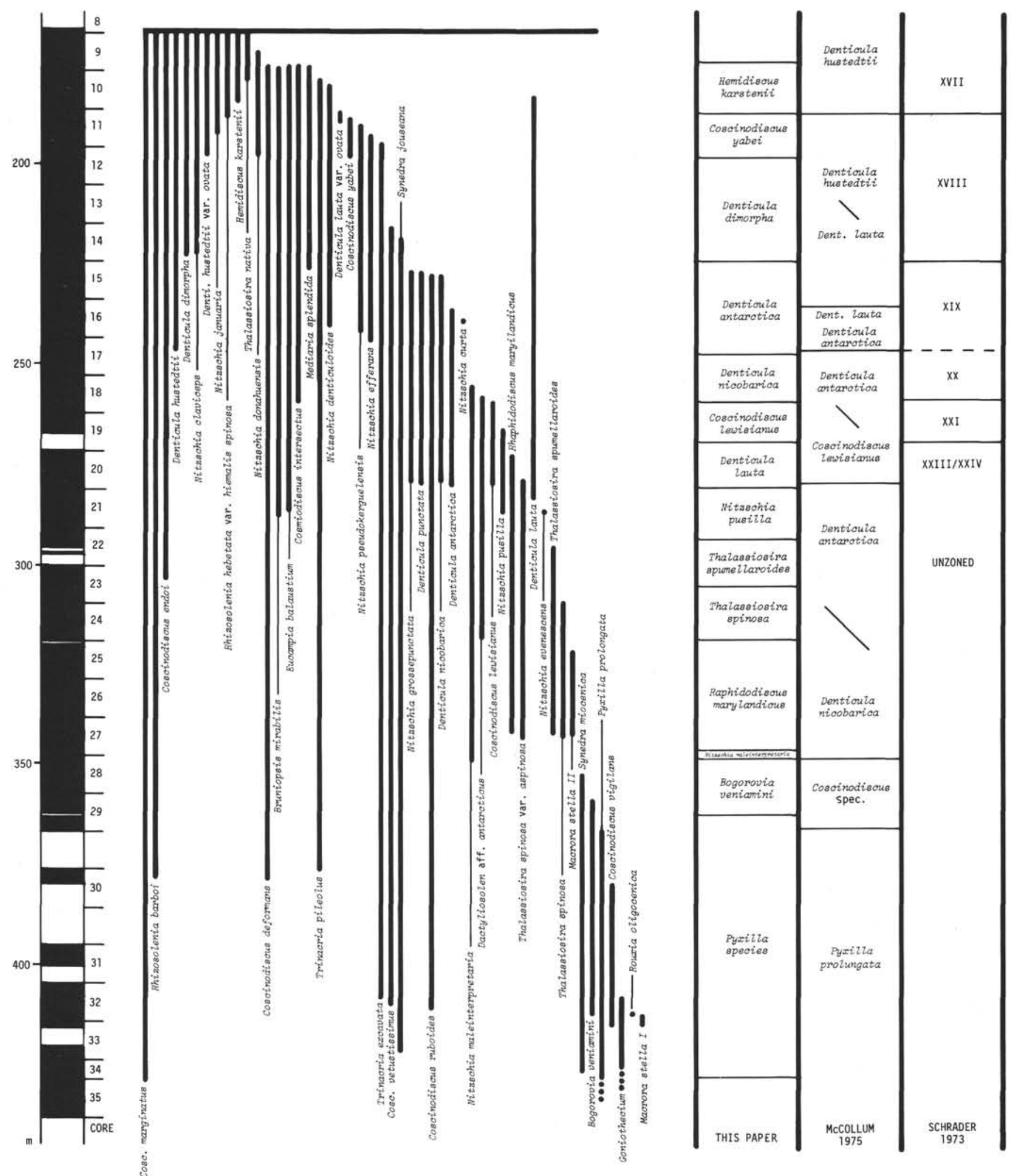

Figure 14. Ranges of selected diatom species from Site 278 with correlation to the diatom biostratigraphic zonation of McCollum (1975), Schrader (1973a), and that established in this paper. Recovered intervals are indicated in black in the left column.

ma hiemalis, $R$. minima (first occurrence in the lower part of this zone), $R$. styliformis, Rouxia californica, $R$. naviculoides, Stephanopyxis turris, Thalassiothrix longis- sima, Thalassionema nitzschioides, Trinacria excavata. Synedra jouseana has its last occurrence near the lower part of this zone. Denticula aff. kamtschatica and D. aff. 
antarctica are easily confused but may only be aberrant forms of Denticula hustedtii or D. lauta.

Comparison with the zonations of other workers: Denticula dimorpha appears first in NPD Zone XIX in North Pacific sediments (Schrader, 1973a, b). This zone is correlative to the Denticula hustedtii/Denticula lauta Zone of McCollum (1975), to the Denticula lauta/Kozloviella edita Zone of Jousé (1974), and to the Cussia paleacea Zone of Schrader and Burckle (in preparation).

Type locality: DSDP Leg 29, Site 278, Samples 14-6, $50-51 \mathrm{~cm}$ to $12-3,50-51 \mathrm{~cm}$.

\section{Denticula antarctica Partial-Range Zone}

Definition: The base of this zone has been defined by the first occurrence of Denticula hustedtii, the top by the last occurrence of Denticula nicobarica.

Discussion: Other floral elements include Actinocyclus ingens, Bruniopsis mirabilis, Coscinodiscus deformans, C. endoi, C. marginatus, C. ruboides, Cosmiodiscus intersectus, Denticula hustedtii, D. hyalina, D. lauta, D. nicobarica, D. punctata, Ethmodiscus rex, Eucampia balaustium, Melosira sulcata, Nitzschia efferens, $N$. grossepunctata, $N$. pseudokerguelensis (first occurrence near base of this zone), N. sp. 17 (within the lower part of this zone), Rhizosolenia alata, $R$. hebetata forma hiemalis, $R$. styliformis, Rouxia antarctica, $R$. californica, Stephanopyxis "turris," Synedra jouseana, Thalassionema nitzschioides, Thalassiothrix longissima, Trinacria excavata, $T$. pileolus. The last occurrence of Denticula antarctica and the first occurrence of Nitzschia denticuloides is in this zone.

Comparison with the zonations of other workers: This zone is correlative to the Denticula lauta/Denticula antarctica Zone of McCollum (1975), to the NPD Zone XX of Schrader (1973a), to the Denticula nicobarica Zone of Schrader and Burckle (in preparation), and to the Bogorovia veniamini Zone and basal part of the Coscinodiscus marginatus var. Zone of Jousé (1974).

Type locality: DSDP Leg 29, Site 278, Samples 17-3, $50-51 \mathrm{~cm}$ to $15-2,50-51 \mathrm{~cm}$.

\section{Denticula nicobarica Partial-Range Zone}

Definition: The base of this zone has been defined by the last occurrence of Coscinodiscus lewisianus, the top by the first occurrence of Denticula hustedtii. Within the lower part of this zone Dactyliosolen aff. antarctica and Nitzschia maleinterpretaria become extinct.

Discussion: Other floral elements include Actinocyclus ingens, Bruniopsis mirabilis, Coscinodiscus endoi, C. marginatus, C. ruboides, Cosmiodiscus intersectus, Denticula antarctica, D. hyalina, D. lauta, D. nicobarica, D. punctata, Ethmodiscus rex, Eucampia balaustium, Melosira sulcata, Nitzschia grossepunctata, Rhizosolenia barboi, $R$. hebetata forma hiemalis, Stephanopyxis turris, Thalassiothrix longissima, Thalassionema nitzschioides, Trinacria excavata, $T$. pileolus.

Comparison with the zonations of other workers: This zone is correlative to the Denticula nicobarica/Cussia paleacea zones of Schrader and Burckle (in preparation), to the Denticula antarctica/Denticula lauta Zone of McCollum (1975), and to the NPD Zone XXIII (?) of Schrader (1973a).
Type locality: DSDP Leg 29, Site 278, Samples 18-5, $50-51 \mathrm{~cm}$ to $17-4,50-51 \mathrm{~cm}$.

\section{Coscinodiscus lewisianus Partial-Range Zone}

Definition: The base of this zone has been defined by the last occurrence of Raphidodiscus marylandicus, the top by the last occurrence of Coscinodiscus lewisianus.

Discussion: Other floral elements include Actinocyclus ingens, Coscinodiscus deformans, $C$. endoi, $C$. lewisianus, C. marginatus, C. ruboides, Dactyliosolen aff. antarctica, Denticula antarctica, D. hyalina, D. lauta, D. nicobarica, Ethmodiscus rex, Eucampia balaustium, Melosira sulcata, Nitzschia grossepunctata, Rhizosolenia barboi, $R$. hebetata forma hiemalis, Rouxia californica, Stephanopyxis turris, Synedra jouseana, Thalassiothrix longissima, Trinacria excavata, $T$. pileolus. Coscinodiscus lewisianus becomes extinct in the North Pacific at the base of NPD Zone XX and in the Equatorial Pacific within the Coscinodiscus sp. Zone.

Comparison with the zonations of other workers: This zone can be correlated to the NPD Zone XXI of Schrader (1973a), to the Coscinodiscus sp. Zone of Schrader and Burckle (in preparation), and to the Denticula antarctica/Coscinodiscus lewisianus Zone of McCollum (1975).

Paleomagnetic stratigraphy: An indirect correlation to the upper part of Paleomagnetic Epoch 15 can be concluded by the range of Coscinodiscus lewisianus.

Type locality: DSDP Leg 29, Site 278, Samples 19-3, $50-51 \mathrm{~cm}$ to $18-6,50-51 \mathrm{~cm}$.

\section{Denticula lauta Partial-Range Zone}

Definition: The base of this zone is defined by the first occurrence of Coscinodiscus lewisianus, Denticula antarctica, Denticula lauta, and D. punctata, the top by the last occurrence of Raphidodiscus marylandicus.

Discussion: Other floral elements include Actinocyclus ingens, Asteromphalus hookeri, Bruniopsis mirabilis, Coscinodiscus deformans, C. endoi, $C$. marginatus, C. vetustissimus, Dactyliosolen aff. antarcticus, Denticula antarctica, D. lauta, D. punctata, D. punctata var. hustedtii, Ethmodiscus "rex," Eucampia balaustium, Melosira "sulcata," Nitzschia grossepunctata, Raphidodiscus marylandicus, Rhizosolenia barboi, R. styliformis, Rouxia californica, Stephanopyxis "turris," Synedra jouseana, Thalassionema nitzschioides, Thalassiothrix longissima, Trinacria excavata, $T$. pileolus. Denticula nicobarica evolves within this zone from its immediate ancestor Nitzschia maleinterpretaria. Raphidodiscus marylandicus becomes extinct in tropical sediments in the Anellus californicus Zone (Schrader and Burckle, in preparation).

Comparison with the zonations of other workers: This zone is correlative to the Denticula antarctica/Coscinodiscus lewisianus Zone of McCollum (1975), to the Anellus californicus Zone of Schrader and Burckle (in preparation), to the basal part of NPD Zone XXIII of Schrader (1973a).

Paleomagnetic stratigraphy: An indirect correlation to the lower part of magnetic epoch 15 can be implied by the range of Raphidodiscus marylandicus.

Type locality: DSDP Leg 29, Site 278, Samples 20-6, $50-51 \mathrm{~cm}$ to $20-1,60-61 \mathrm{~cm}$. 
TABLE 12A

Distribution of Diatoms at Site 278 (Leg 29)

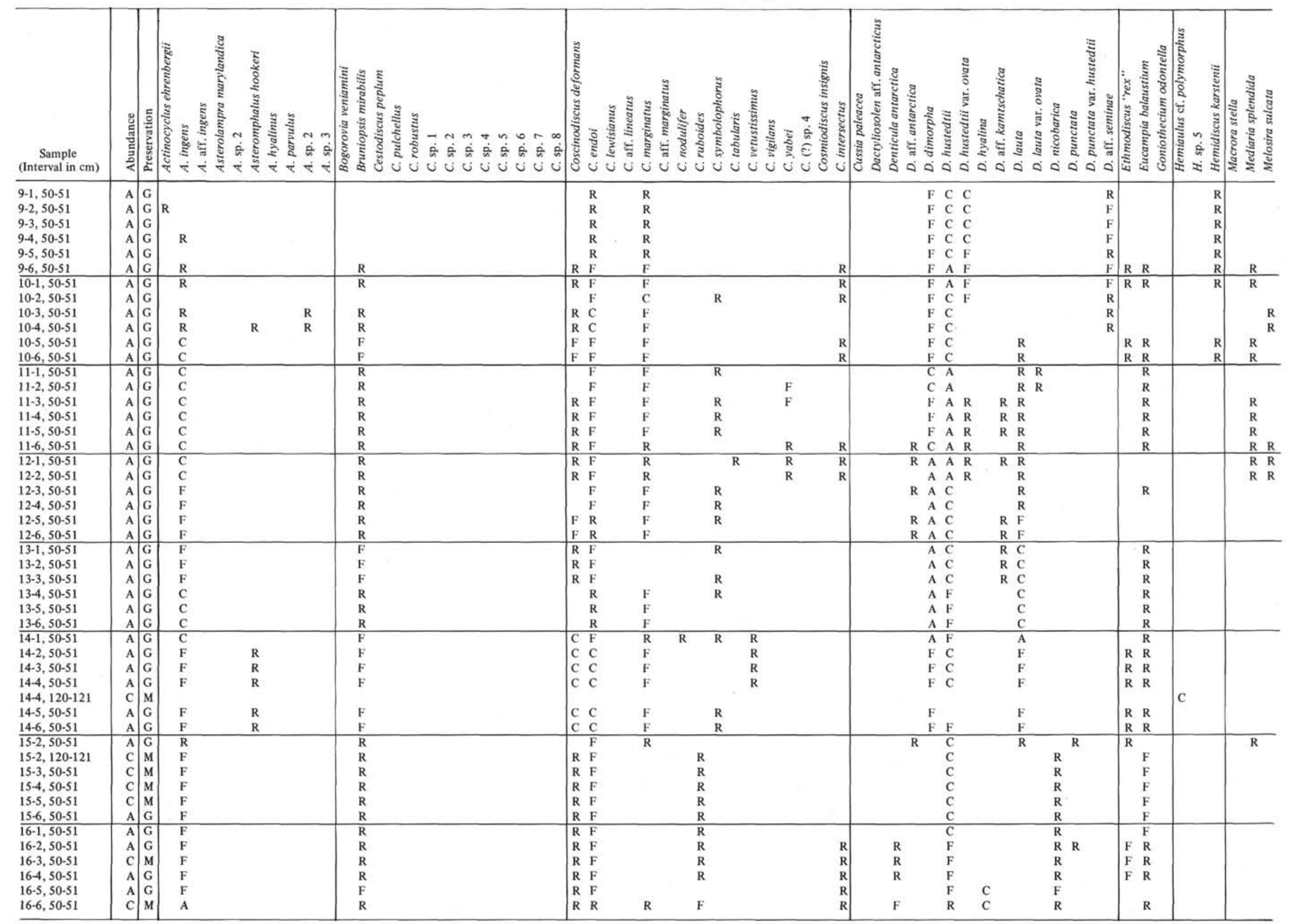




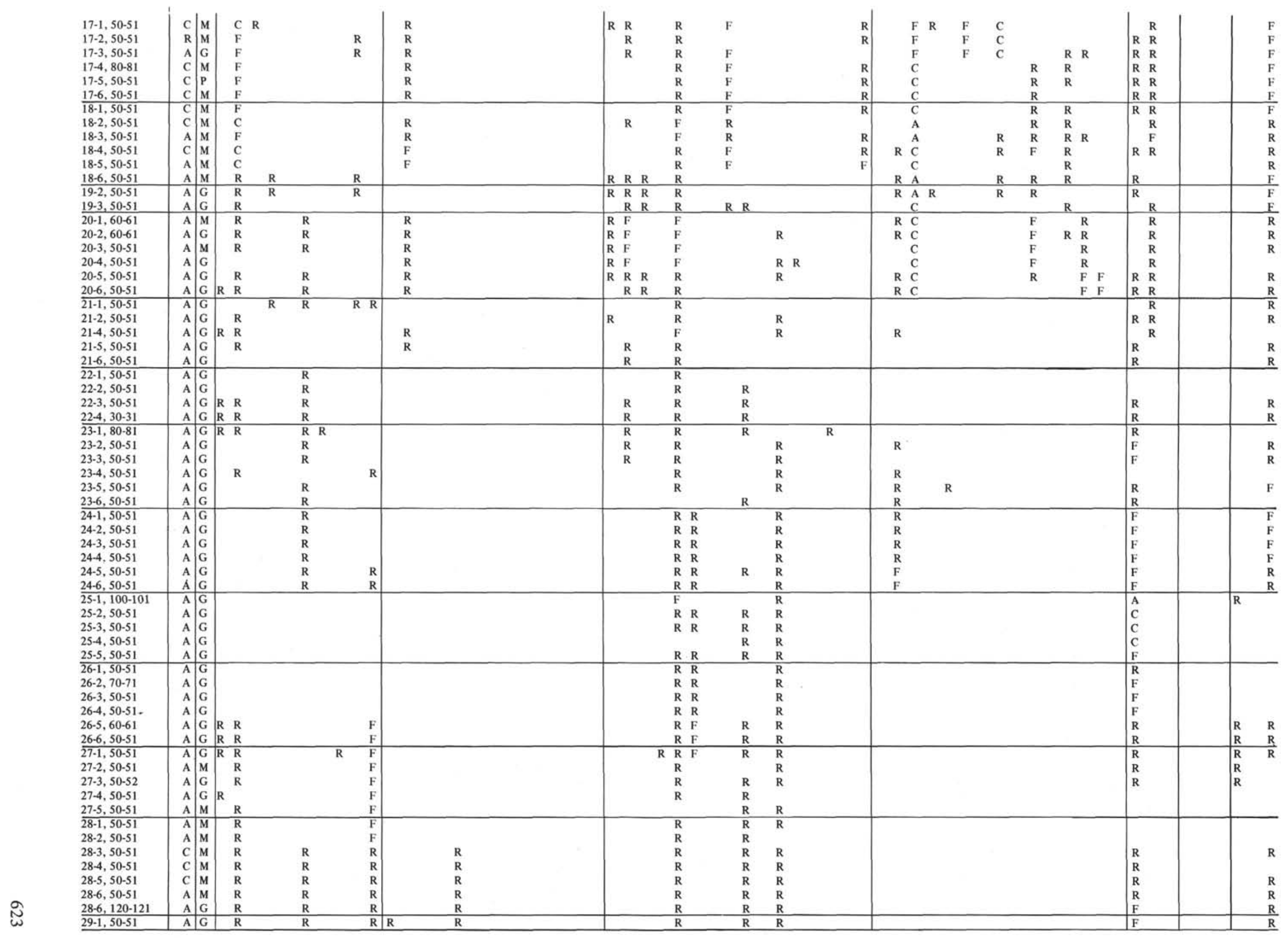


TABLE 12A - Continued

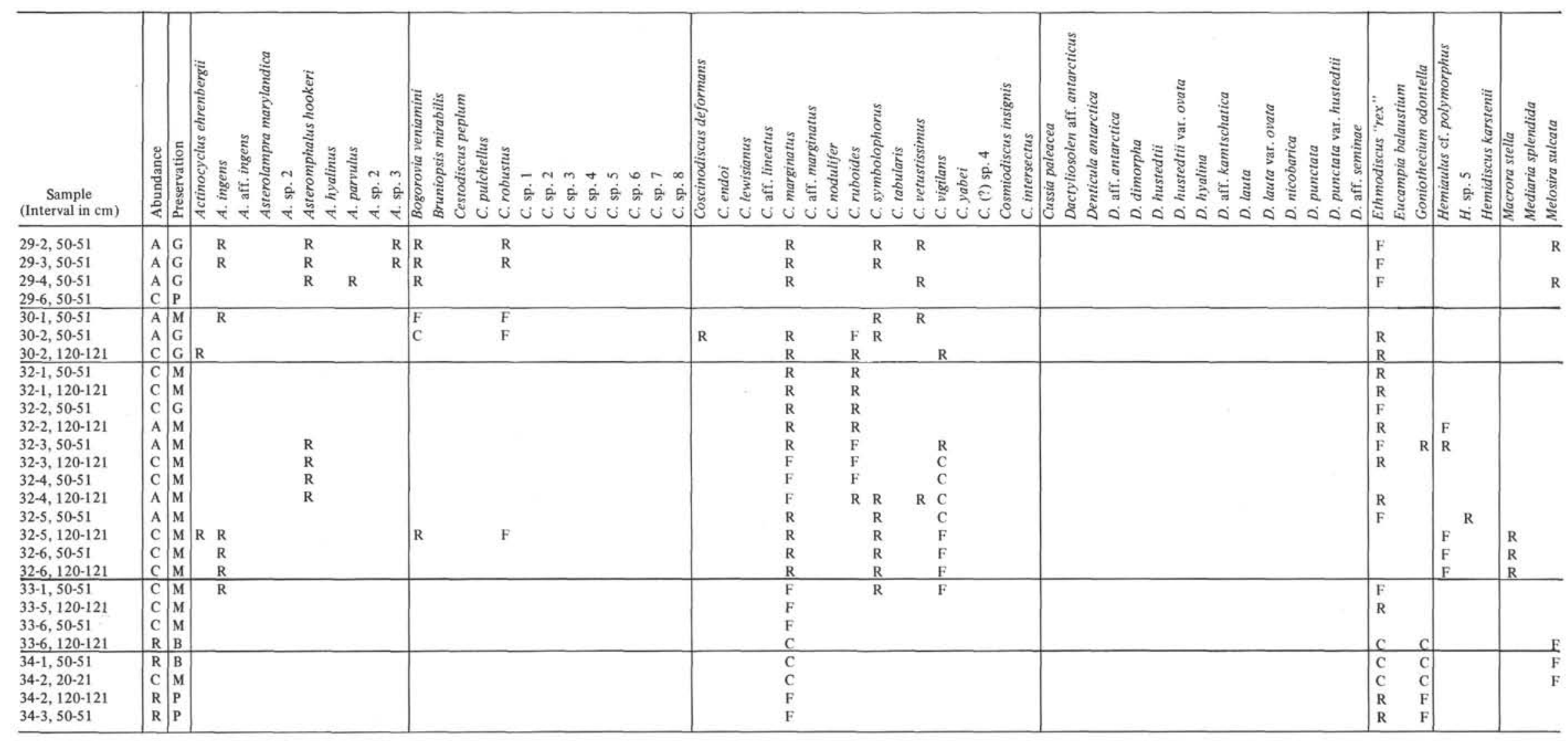


Nitzschia pusilla Partial-Range Zone

Definition: The base of this zone has been defined by the last occurrence of Thalassiosira spumellaroides, the top by the first occurrence of Coscinodiscus lewisianus, Denticula punctata, D. antarctica, and $D$. lauta.

Discussion: Other floral elements include Actinocyclus ehrenbergii, A. ingens, Asteromphalus hookeri, Coscinodiscus endoi, C. marginatus, C. symbolophorus, C. vetustissimus, Ethmodiscus "rex," Eucampia balaustium, Melosira sulcata, Nitzschia maleinterpretaria, N. pusilla, Rhizosolenia barboi, $R$. hebetata forma hiemalis, $R$. styliformis, Rouxia californica, $R$. isopolica, Stephanopyxis "turris," Synedra jouseana, Thalassionema nitzschioides, Thalassiosira spinosa var. aspinosa, Thalassiothrix longissima, Trinacria excavata, $T$. pileolus. Denticula antarctica and Coscinodiscus lewisianus both occur at the same time as Denticula lauta. This disagrees with McCollum (1975). Denticula punctata first occurs in the North Pacific at the base of NPD Zone XXIII, coinciding with Denticula hustedtii, whereas, in the South Pacific D. hustedtii appears later.

Comparison with the zonations of other workers: This zone is correlative to the Denticula nicobarica/Denticula antarctica Zone of McCollum (1975).

Type locality: DSDP Leg 29, Site 278, Samples 22-2, $50-51 \mathrm{~cm}$ to $21-1,50-51 \mathrm{~cm}$.

\section{Thalassiosira spumellaroides Partial-Range Zone}

Definition: The base of this zone has been defined by the last occurrence of Thalassiosira spinosa and by the first occurrence of Coscinodiscus endoi; the top by the last occurrence of Thalassiosira spumellaroides.

Discussion: Other floral elements include Actinocyclus ehrenbergii, A. ingens, Asteromphalus hookeri, Coscinodiscus endoi, C. symbolophorus, C. vetustissimus, Ethmodiscus "rex," Melosira sulcata, Navicula sp. 1, Nitzschia maleinterpretaria, Rhizosolenia barboi, $R$. hebetata forma hiemalis, $R$. styliformis, Rouxia californica, Stephanopyxis "turris," Thalassiosira spinosa var. aspinosa, $T$. spumellaroides, Thalassionema nitzschioides, Thalassiothrix longissima, Trinacria excavata, $T$. pileolus.

Comparison with the zonations of other workers: This zone is correlative with the Denticula nicobarica Zone of McCollum (1975).

Type locality: DSDP Leg 29, Site 278, Samples 23-3, $50-51 \mathrm{~cm}$ to $22-3,50-51 \mathrm{~cm}$.

\section{Thalassiosira spinosa Partial-Range Zone}

Definition: The base of this zone is defined by the first occurrence of Navicula sp. 1, the top by the last occurrence of Thalassiosira spinosa and by the first occurrence of Coscinodiscus endoi.

Discussion: Other floral elements include Asteromphalus hookeri, Coscinodiscus marginatus, $C$. aff. marginatus, C. symbolophorus, C. vetustissimus, Dactyliosolen aff. antarcticus, Ethmodiscus "rex," Melosira sulcata, Navicula sp. 1, Nitzschia maleinterpretaria, Rhizosolenia barboi, $R$. hebetata forma hiemalis, $R$. styliformis, Rouxia californica, Synedra jouseana, Stephanopyxis "turris," Thalassionema nitzschioides, Thalassiosira spinosa, T. spinosa var. aspinosa, $T$. spumellaroides, Trinacria excavata, $T$. pileolus. The oc- currence of spinous Thalassiosira species in the early Miocene is comparable to the occurrence of similar species within the Pliocene in tropical marine sediments (Thalassiosira convexa, $T$. convexa var. aspinosa, T. praeconvexa, Burckle, 1972; Schrader, 1974b). Coscinodiscus endoi was here found lower in the section than described by McCollum (1975).

Comparison with the zonations of other workers: This zone is correlative to the Denticula nicobarica Zone of McCollum (1975) and with the Bogorovia veniamini Zone of Jousé (1974).

Type locality: DSDP Leg 29, Site 278, Samples 24-6, $50-51 \mathrm{~cm}$ to $23-5,50-51 \mathrm{~cm}$.

\section{Raphidodiscus marylandicus Partial-Range Zone}

Definition: The base of this zone has been defined by the first occurrence of Raphidodiscus marylandicus, the top by the first occurrence of Navicula sp. 1 .

Discussion: Other floral elements include Actinocyclus ehrenbergii, A. ingens, Asteromphalus sp. 3, Coscinodiscus marginatus, C. aff. marginatus, C. symbolophorus, C. vetustissimus, Ethmodiscus “rex," Macrora stella, Melosira "sulcata," Nitzschia maleinterpretaria, Raphidodiscus marylandicus, Rhizosolenia barboi, $R$. hebetata forma hiemalis, $R$. styliformis, Rouxia californica, R. isopolica, Stephanopyxis "turris," Synedra jouseana, Thalassionema hirosakiensis, T. nitzschioides, Thalassiosira spinosa, $T$. spinosa var. aspinosa, $T$. spumellaroides, Thalassiothrix longissima, Trinacria excavata, $T$. pileolus. Navicula sp. 1 has not yet been found by other workers, thus a direct correlation to the zonation of others is limited.

Comparison with the zonations of other workers: This zone is correlative to the Denticula nicobarica Zone of McCollum (1975) and to the Bogorovia veniamini Zone of Jousé (1974).

Type locality: DSDP Leg 29, Site 278, Samples 27-2, $50-51 \mathrm{~cm}$ to $25-1,100-101 \mathrm{~cm}$.

\section{Nitzschia maleinterpretaria Partial-Range Zone}

Definition: The base of this zone has been defined by the first evolutionary appearance of Nitzschia maleinterpretaria, the top by the first occurrence of Raphidodiscus marylandicus.

Discussion: Other floral elements include Actinocyclus ehrenbergii, A. ingens, Asteromphalus sp. 3, Coscinodiscus marginatus, C. symbolophorus, $C$. vetustissimus, Nitzschia maleinterpretaria, Rhizosolenia hebetata forma hiemalis, $R$. styliformis, Stephanopyxis "turris," Synedra jouseana, Thalassionema nitzschioides. Trinacria excavata, $T$. pileolus. Raphoneis sp. McCollum (1975) (pl. 11, fig. 9, 10) was not detected in this zone, the same is true for Coscinodiscus nodulifer. Denticula nicobarica evolves later from Nitzschia maleinterpretaria, and this event has been defined biometrically. Nitzschia maleinterpretaria differs from Denticula nicobarica by the absence of secondary pseudoseptae, but is otherwise close to $D$. nicobarica. Raphidodiscus marylandicus has an expanded range in cold biofacies and ranges well into the early Miocene (see Andrews, 1974).

Comparison with the zonations of other workers: This zone is correlative to the lower part of the Denticula nicobarica Partial-Range Zone of McCollum (1975). 
TABLE 12B

న్

Distribution of Diatoms at Site 278 (Leg 29)

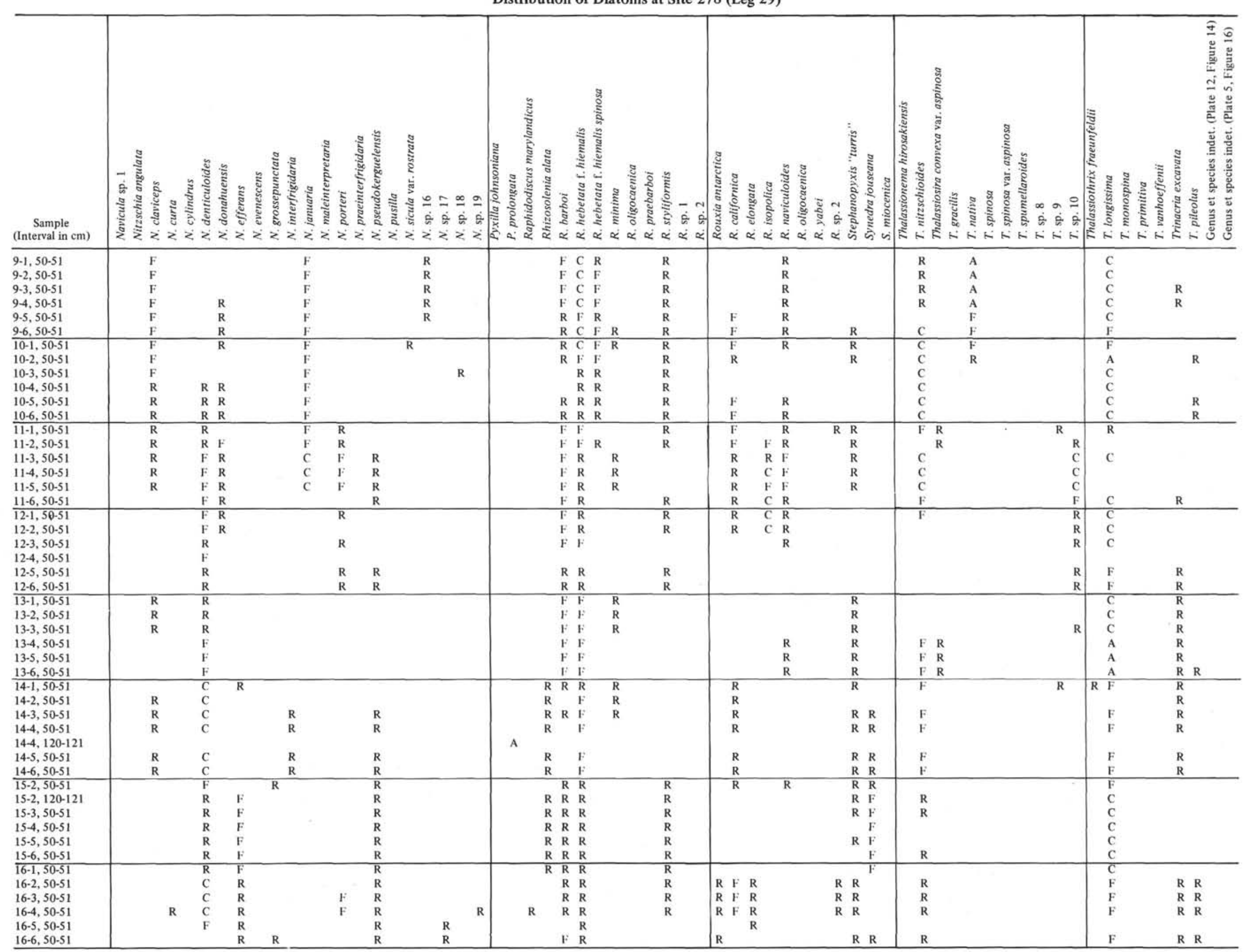







TABLE 12B - Continued

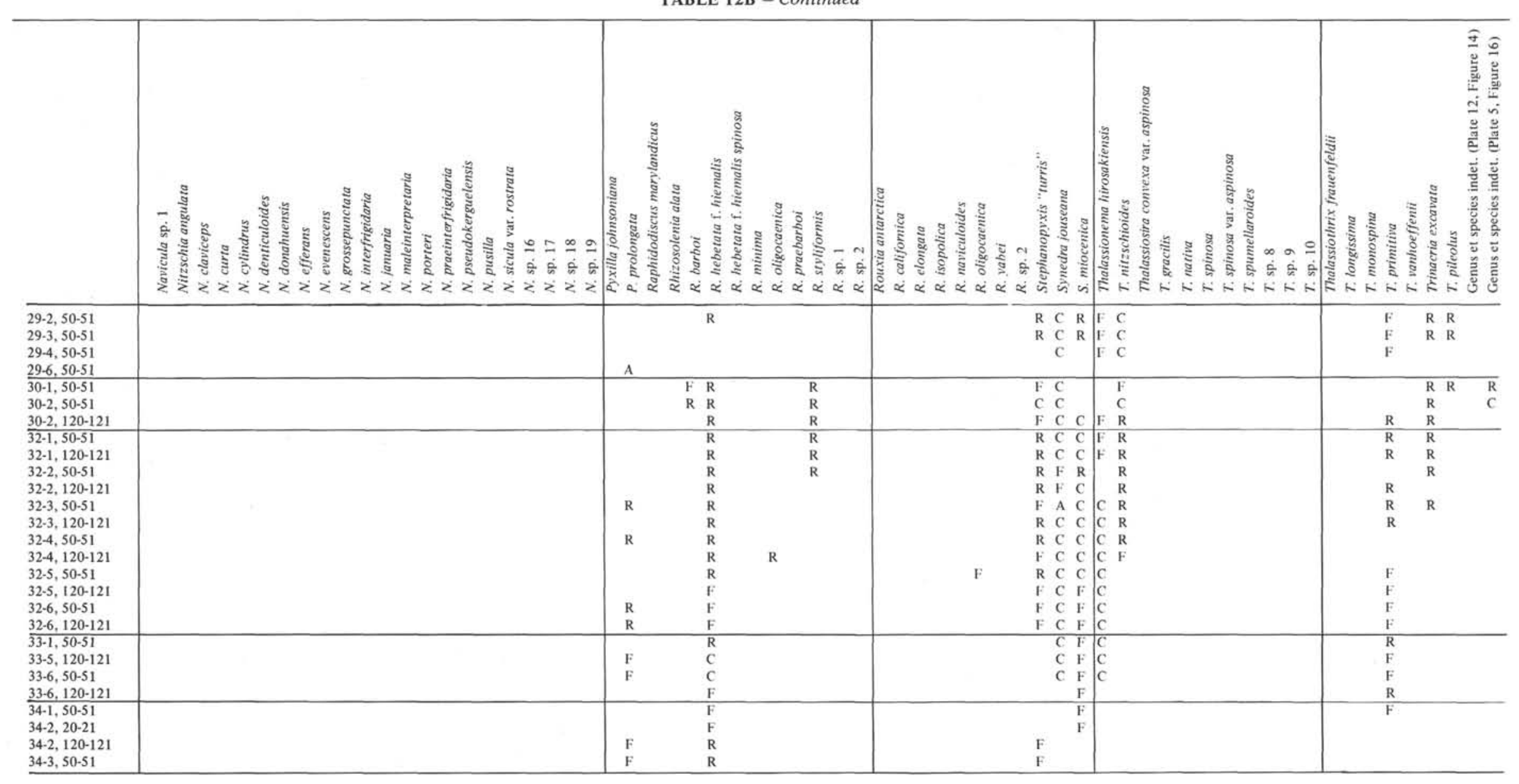


Type locality: DSDP Leg 29, Site 278, Samples 27-5, $50-51 \mathrm{~cm}$ to $27-3,50-51 \mathrm{~cm}$.

\section{Bogorovia veniamini Partial-Range Zone}

Definition: The base of this zone has been defined by the extinotion of Pyxilla species, the top by the first appearance of Nitzschia maleinterpretaria.

Discussion: Other floral elements include Actinocyclus ehrenbergii, A. ingens, Asterolampra hookeri, Bogorovia veniamini, Asteromphalus robustus (?), Coscinodiscus marginatus, C. symbolophorus, $C$. vetustissimus, Ethmodiscus "rex," Melosira sulcata, Rhizosolenia barboi, $R$. hebetata forma hiemalis, $R$. styliformis, Stephanopyxis "turris," Synedra jouseana, $S$. miocenica, Thalassionema hirosakiensis, T. nitzschioides, Thalassiothrix primitiva, Trinacria excavata, $T$. pileolus. The base of this zone is defined to coincide with the Oligocene/Miocene boundary and was not defined by McCollum due to taxonomic uncertainties concerning Denticula nicobarica.

Comparison with the zonations of other workers: This zone is correlative with the Coscinodiscus sp. Zone of McCollum (1975) but has no Coscinodiscus nodulifer specimens; it is correlative to the lowermost part of the Bogorovia veniamini Zone of Jousé (1974) and is lower early Miocene in age.

Type locality: DSDP Leg 29, Site 278, Samples 29-3, $50-51 \mathrm{~cm}$ to $28-1,50-51 \mathrm{~cm}$.

\section{Pyrgupyxis Species Partial-Range Zone}

Definition: The base of this zone has not been defined. The top is defined by the extinction of Pyrgupyxis johnsoniana and all Pyrgupyxis species.

Discussion: Other floral elements include Actinocyclus ehrenbergii, A. ingens, Coscinodiscus marginatus, C. ruboides, $C$. symbolophorus, $C$. vigilans, Ethmodiscus "rex," Goniothecium odontella, Hemiaulus cf. polymorphus, Macrora stella (?), Pyrgupyxis prolongata, Rhizosolenia hebetata forma hiemalis, Stephanopyxis "turris," Synedra jouseana, S. miocenica, Thalassiothrix primitiva.

Bogorovia veniamini was found by Jousé (1974) at St. $599618\left(10^{\circ} 58^{\prime} \mathrm{N}, 153^{\circ} 23^{\prime} \mathrm{W}, 43\right.$ cruise of the R.S. $V$ itya), and the total range was used to define her lower Miocene Bogorovia veniamini Zone. Since Bogorovia veniamini was found in the Equatorial Pacific and Mediterranean sections ranging well into the early Miocene, the range here has only local significance. Other important species are Coscinodiscus vigilans, which was found by Jousé (1974) to range from late Oligocene into the late Miocene. This species also becomes extinct here at the top of this zone. Macrora stella (?), a form very close to those individuals found within the middle Miocene, is found in small numbers throughout the zone.

Comparison with the zonations of other workers: This zone is correlative to the uppermost part of the Coscinodiscus vigilans-Craspedodiscus coscinodiscus Zone of Jousé (1974), and to the Pyxilla prolongata Partial-Range Zone of McCollum (1975).

Type locality: DSDP Leg 29, Site 278, Samples 34-3, $50-51 \mathrm{~cm}$ to $29-4,50-51 \mathrm{~cm}$.

\section{SYSTEMATICS AND FLORAL SEQUENCE}

The genera are arranged alphabetically and species alphabetically with each genus. Species and varieties are treated according to the classifications of Hustedt (1930-1959); Hendey $(1937,1964)$, Karsten (1907), Kanaya (1957, 1959), Koizumi (1968, 1973), Schrader (1973a, 1974a, b), Van Landingham (1967-1971), and SheshukovaPoretzkaya (1967), and others whose descriptions have been strictly followed in identifying species.

New species are described and their holotypes and paratypes designated. Holotypes are deposited in the author's type collection.

Unidentified species are numbered or grouped and illustrated. An attempt was made to catalog all diatom species found. Almost all individuals illustrated were marked on the slides with a diamond-tipped marker (Schrader, 1974a, b).

In the synonymies of species that have been previously described, I have included, in most cases, only the reference to the original description and figure. Reference to a new combination, if the generic name now used differs, is included. A reference has also been added to the paper defining the present concept of the species.

\section{Genus ACTINOCYCLUS Ehrenberg (1837)}

\section{Actinocyclus curvatulus Janisch in A. Schmidt (1878)}

(No illustration)

Description: Hustedt (1930), p. 538, fig. 307. Numerous specimens were found in the Quaternary sediments of Leg 35. No biostratigraphic investigation was done due to incomplete sections.

\section{Actinocyclus divisus (Grunow) Hustedt (1958)}

(No illustration)

Description: Hustedt (1958), p. 129-130, pl. 8, fig. 81. This species was found rarely in Holocene to Pleistocene sediments from the Antarctic. There was no opportunity to clarify the range of this species with the present type of material.

\section{Actinocyclus ehrenbergii Ralfs in Pritchard (1861) (No illustration)}

Description: Hustedt (1930), p. 525-532, numerous figures. No subdivisions of this species have been made here due to its rarity.

$$
\begin{gathered}
\text { Actinocyclus ellipticus Grunow in Van Heurck (1881) } \\
\text { (No illustration) }
\end{gathered}
$$

Description: Hustedt (1930), p. 533, fig. 303. Traces of this species were found in Miocene sediments. It has therefore not been included in the range chart of DSDP Leg 29, Site 278.

\section{Actinocyclus ingens Rattray (1890)}

(Plate 13, Figure 8)

Description: Kanaya (1971), p. 554, numerous figures.

\section{Actinocyclus aff. ingens Rattray (1891)}

(Plate 11, Figures 6, 7)

All specimens placed here have an almost flat valve surface, are small $(10-20 \mu \mathrm{m})$ in diameter and have an almost invisible pseudonodulus (close to the margin). McCollum (1975) points out that the typical undulated forms of Actinocyclus ingens tend to be frequent in the Pliocene and those forms which are smaller and placed here tend to be more common in Miocene sediments; this statement cannot be determined using the present material.

\section{Genus ACTINOPTYCHUS Ehrenberg (1839)}

\section{Actinoptychus undulatus (Bail.) Ralfs in Pritchard (1861) (No illustration)}

Specimens close to $A$. undulatus and other actinoptychi with sixsector division occur rarely. Therefore they are not referred to in the species list for Site 278. It is also at present impossible to define the range and taxonomic position of specific types within this "group taxon." 
Genus ASTEROLAMPRA Ehrenberg (1845)

Asterolampra marylandica Ehrenberg (1845)

(No illustration)

Description: Hustedt (1930), p. 485-487, fig. 271. This species was found rarely in Miocene sediments of Site 278.

\section{Asterolampra sp. 2}

(Plate 8, Figure 2)

No similar Asterolampra species was found in the literature. Since this species occurred rarely and individuals were fragmented, this was not taxonomically studied.

\section{Genus ASTEROMPHALUS Ehrenberg (1844)}

\section{Asteromphalus hookeri Ehrenberg (1844)}

(No illustration)

Description: Hustedt (1958), p. 127-128, pl. 8, fig. 89. This species was found frequently in Quaternary sediments of the Bellingshausen Sea area. Due to taxonomic uncertainties of Site 278 specimens, no biostratigraphic range was determined.

\section{Asteromphalus hyalinus Karsten (1905) \\ (Plate 8, Figure 7)}

Description: Karsten (1905), p. 90, pl. 8, fig. 15; Hustedt (1958), p. 128 , pl. 8 , fig. $84-87$.

\section{Asteromphalus parvulus Karsten (1905)}

(Plate 8, Figures 3, 6)

Description: Karsten (1905), p. 90, pl. 8, fig. 14; Hustedt (1958), p. 128 , pl. 8 , fig. 91 .

\section{Asteromphalus sp. 2}

(Plate 8, Figure 1)

No similar Asteromphalus species was found in the literature. Several specimens were found and do differ from Asteromphalus sp. 3 by the much finer areolation of the sectors. Due to the fact that the taxonomy of the genus Asteromphalus is uncertain for some species, no further taxonomic study was made here.

\section{Asteromphalus sp. 3 \\ (Plate 8, Figure 4)}

This species is close to Asteromphalus sp. 2, but differs by the much coarser areolation of the sectors ( 5 in $10 \mu \mathrm{m}$ ). Otherwise, the statement concerning $A$. sp. 2 is valid also for this species.

\section{Genus BOGOROVIA Jousé $(1973,1974)$}

The taxonomic position of the genus Bogorovia and Cussia will be treated in a separate paper by the present author and A. Gombos.

\section{Bogorovia veniamini Jousé $(1973,1974)$}

(Plate 5, Figures 22, 23)

Description: Jousé $(1973,1974)$, p. 351, pl. 4, fig. 1-3.

\section{Genus BRUNIOPSIS (Tempère) Karsten (1928) \\ Bruniopsis mirabilis (Brun) Karsten (1928) \\ (Plate 14, Figure 1)}

Description: As Brightwellia? mirabilis, Brun in Brun and Tempère (1890), p. 27, pl. 8, fig. 1. This species only occurs fragmented but is easily recognizable by the structure and can be differentiated from Ethmodiscus rex fragments.

\section{Genus CESTODISCUS Greville (1865)}

Taxonomy of this genus and species needs drastic revision. At this time, only a very few species have been found, grouped, and photographed. A complete revision will be presented at a later date, probably by the time a complete lower Tertiary diatom biostratigraphy is established. All species close to the genus Actinocyclus but without a pseudonodulus are grouped here.
Cestodiscus peplum Brun (1891)

(Plate 5, Figure 17)

Description: Brun (1891), p. 6, pl. 19, fig. 5.

Cestodiscus pulchellus Greville (1866)

(Plate 13, Figure 5)

Description: Greville (1866), p. 123, pl. 11, fig. 5 .

Cestodiscus robustus Jousé (1973, 1974)

(Plate 10, Figure 2)

Description: Jousé $(1973,1974)$, p. 345, pl. 1, fig. 14, 15.

Cestodiscus sp. 1

(Plate 12, Figure 6)

Cestodiscus sp. 2

(Plate 12, Figure 7)

Cestodiscus sp. 3

(Plate 12, Figure 15)

Cestodiscus sp. 4

(Plate 12, Figure 1)

Cestodiscus sp. 5

(Plate 12, Figure 3)

Cestodiscus sp. 6

(Plate 12, Figure 4)

Cestodiscus sp. 7

(Plate 13, Figure 3)

Cestodiscus sp. 8

(Plate 13, Figure 6)

Genus CHARCOTIA Peragallo (1921)

Charcotia actinochilus (Ehr.) Hustedt (1958)

(No illustration)

Description: Hustedt (1958), p. 122-126, pl. 7, fig. 57-80.

Genus COCCONEIS Ehrenberg (1838)

Cocconeis various species

(No illustration)

Genus COSCINODISCUS Ehrenberg (1838)

Coscinodiscus deformans sp. nov.

(Plate 11, Figures 1, 2)

Description: Cells discoid, valves flat, $40-36 \mu \mathrm{m}$ in diameter. Valve surface covered with rounded to rectangular areolae, areolae arranged in primary and secondary radial lines, approx. 6-7 areolae in $10 \mu \mathrm{m}$. Central area distinct, eccentrically situated with a few scattered smaller areolae, separated from the valves areolation by hyaline elliptical ring. Margin finely punctate with 2-4 lines of punctae, 11 in $10 \mu \mathrm{m}$ in between with labiate processes, approx. 9-10 $\mu \mathrm{m}$ apart. Marginal structure separated from valve structure by a hyaline ring.

Discussion: This species differs from $C$. endo $i$ by its eccentric center and by the smaller areolae at the margin. It differs from Charcotia actinochilus (Ehr.) Hustedt by the presence of an eccentrically situated pore (? similar to the nodulus in $C$. nodulifer or $C$. endoi).

Holotype: Plate 11, Figure 1, from DSDP Leg 29, Sample 278-141, $50-51 \mathrm{~cm}$, southwest Pacific.

Paratype: Plate 11, Figure 2.

\section{Coscinodiscus endoi Kanaya (1959)}

(Plate 11, Figures 4, 8-10, 12)

Description: Kanaya (1959), p. 76-77, pl. 3, fig. 8-11; Koizumi (1968), p. 211, pl. 32, fig. 21, 22.

\section{Coscinodiscus kolbei Jousé (1962)} (No illustration)

Description: Donahue (1970), p. 202, pl. 5, fig. A-C. 
Coscinodiscus lentiginosus Janisch in A. Schmidt (1878) (No illustration)

Description: Hustedt (1958), p. 116, pl. 4, fig. 22-25.

Coscinodiscus aff. lineatus Ehrenberg (1838)

(Plate 13, Figures 1, 2)

Specimens found do differ from the original description in having a hyaline rim near the margin.

Coscinodiscus lewisianus Greville (1866)

(Plate 14, Figure 3)

Description: Kanaya (1971), p. 555, pl. 40.5, fig. 4-6.

Coscinodiscus marginatus Ehrenberg (1841)

(Plate 12, Figure 2)

Description: Hustedt (1930), p. 416-418, fig. 223.

Coscinodiscus aff. marginatus Ehrenberg (1841) (Plate 10, Figure 3)

Differs from $C$. marginatus by its coarser striated margin.

Coscinodiscus nodulifer A. Schmidt (1878)

(Plate 11, Figure 3)

Description: Hustedt (1930), p. 426-427, fig. 229.

\section{Coscinodiscus ruboides n. sp.} (Plate 6, Figures 4, 8)

Description: Cells discoid in valve view, cuneiform in girdle view. Valves circular, strongly convex, 17-20 $\mu \mathrm{m}$ in diameter. Valve surface covered with a coarse ( 6 in $10 \mu \mathrm{m})$ subhexagonal areolation, radiating from the center (no rosette or central areola) to the margin. Margin approx. 2-3 $\mu \mathrm{m}$ wide with coarse striation, approx. 5-6 in $10 \mu \mathrm{m}$.

Discussion: This species is close to Stephanopyxis species, but differs by the absence of a spine. No similar species has been observed in the literature.

Holotype: Plate 6, Figure 8, from DSDP Leg 29, Sample 278-30-2, $50-51 \mathrm{~cm}$, southwest Pacific.

Paratype: Plate 6, Figure 8.

Coscinodiscus symbolophorus group

(Plate 7, Figures 1-3; Plate 10, Figures 1, 4, 5)

At this moment it is not possible to solve the taxonomy of this group. They do differ in morphology of the margin and by the different ground plan of the central part with labiate and without labiate processes a.o.

\section{Coscinodiscus tabularis Grunow (1884) (Plate 11, Figure 5)}

Description: Hustedt (1930), p. 427, fig. 230a; Hustedt (1958), p. 119 , pl. 6 , fig. $48-56$.

\section{Coscinodiscus vetustissimus Pantocsek (1886)} (Plate 11, Figure 11)

Description: Hustedt (1930), p. 412, fig. 220.

\section{Coscinodiscus vigilans A. Schmidt (1888)} (Plate 12, Figure 5)

Description: Kolbe (1954), p. 36, pl. 1, fig. 13, 14. Kolbe's figures differ from those pictures in A. Schmidt (1888), pl. 114, fig. 12 in having a coarse striated margin. I do follow Kolbe (1954) and Jousé $(1973,1974)$ because I did not have the opportunity to reinvestigate A. Schmidt's original material from Archangelsk-Kurojedowo.

\section{Coscinodiscus yabei Kanaya (1959)}

(No illustration)

Description: Schrader (1973a), p. 704, pl. 6, fig. 1-6.

Coscinodiscus (?) sp. 4

(Plate 6, Figure 9)

\section{Genus COSMIODISCUS Greville (1866)}

Van Landingham (1969) has rejected the taxonomic position of this genus and combined it with Coscinodiscus e.p. Stephanodiscus e.p. I still consider this genus valid even though it needs drastic revision.

\section{Cosmiodiscus intersectus (Brun) Jousé (1961)}

(Plate 12, Figure 13)

Description: Jousé (1961), p. 68, pl. 2, fig. 9, 10; Koizumi (1973), p. 832 , pl. 4, fig. 12, 13. Sheshukova-Poretzkaya (1967), p. 174, pl. 25, fig. 1 .

Cosmiodiscus insignis Jousé (1961)

$$
\text { (No illustration) }
$$

Description: Jousé (1961), p. 67, pl. 2, fig. 8; Koizumi (1973), p. 832 , pl. 4 , fig. $7-11$.

For further comments see Thalassiosira gracilis (Karsten) Hustedt.

\section{Genus CUSSIA Schrader (1974)}

Cussia paleacea (Grunow) Schrader (1974)

(No illustration)

Description: Kolbe (1954), p. 34, pl. 3, fig. 32.

Genus CYMATOSIRA Grunow (1862)

Cymatosira sp. 1

(Plate 14, Figure 14)

Genus DACTYLIOSOLEN Castracane (1886)

Dactyliosolen aff. antarcticus Castracane (1886)

(No illustration)

Description: Castracane (1886), p. 75, pl. 9, fig. 7. Hendey (1964), p. 142-143. Specimens placed here do differ from $D$. antarcticus by their more robust intercalary bands. No valve has been found up to now, so that taxonomic position is still questionable.

\section{Genus DENTICULA Kützing (1844)}

Denticula antarctica McCollum (1975)

(Plate 4, Figures 3, 22, 23, 25)

Description: McCollum (1975). This species is very close to Denticula hyalina Schrader (1973a), but differs by the flatter valves and by the thinner opal structures. Diagnosis should read as follows: Valves weakly silicified, elliptical to linear elliptical with broadly rounded ends $14-60 \mu \mathrm{m}$ long, $4-8 \mu \mathrm{m}$ wide. Pseudoseptae approx. 6 in $10 \mu \mathrm{m}$, no short ribs between them. Secondary pseudoseptae absent. Valve surface hyaline, elliptical fields in between the pseudoseptae close to the margin (pores?), pore structure on both sides of the mantle; raphe marginal. No indication of any septa could be found as stated by McCollum (1975). At present this species is still kept valid even though it is very close to Denticula hyalina with similar geological range and may be combined with it in the future.

\section{Denticula aff. antaretica McCollum (1975)}

(Plate 4, Figure 1; Plate 3, Figure 16)

Description: McCollum (1975). All specimens which do fit into the Denticula antarctica description but do differ from it by the reduction of the pseudoseptae have been placed here. There was a wide range of reduction until almost Nitzschia-like specimens were found. Taxonomic position will be clarified in a later paper.

\section{Denticula dimorpha Schrader (1973a)}

(Plate 4, Figures 27, 29-32)

Description: Schrader (1973a), p. 704, pl. 1, fig. 37-46; Schrader (1973b), p. 418, pl. 1, fig. 16, 17.

\section{Denticula hustedtii Simonsen and Kanaya (1961) (Plate 4, Figures 2, 4, 8, 9)}

Description: Simonsen and Kanaya (1961), p. 501, pl. 1, fig. 19-25; pl. 2, fig. 36-47. Schrader (1973b), p. 418, pl. 1, fig. 12, 13. 
Denticula hustedtii var. ovata Schrader var. nov.

(Plate 4, Figures 5, 6, 12, 14, 15)

Description: Differs from the species by having more elliptical valves, and a coarser structure. Valves strongly silicified, elliptical with broadly rounded ends, 24-44 $\mu \mathrm{m}$ long, $13-18 \mu \mathrm{m}$ wide with a mean length to width ratio of 2.1 (whereas Denticula hustedtii has a mean length to width ratio of 4.1). Pseudoseptae approx. 2-3 in 10 $\mu \mathrm{m}$, short marginal ribs between the secondary pseudoseptae. Secondary pseudoseptae approx. 2 in between the pseudoseptae and approx. 5 in $10 \mu \mathrm{m}$. Valve surface coarsely punctate, transapical striae $11-12$ in $10 \mu \mathrm{m}$, punctae in decussate arrangement.

Discussion: This variety is placed in Denticula hustedtii because of the presence of the secondary pseudoseptae. It is close to Denticula hustedtii in Schrader (1973a) pl. 2, fig. 29, 30, which was found in the North Pacific in NPD Zones XXVIII-XIX (late middle Miocene to early late Miocene age). Here the species ranges through all of the late Miocene and into the Pliocene.

Holotype: Plate 4, Figure 5, from DSDP Leg 29, Sample 278-9-1, $50-51 \mathrm{~cm}$, southwest Pacific.

Paratype: Plate 4, Figure 6.

\section{Denticula hyalina Schrader (1973a)}

(Plate 4, Figures 17, 24)

Description: Schrader (1973a), p. 704-705, pl. 1, fig. 12-22; Schrader (1973b), p. 418, pl.1, fig. 10,22. As has already been stated this species is close to Denticula antarctica. It ranges in the North Pacific from NPD Zone XXIV to Zone IX (?) and not as stated in Schrader (1973b) fig. 4 only from NPD Zones IX-XIII

\section{Denticula aff. kamtschatica Zabelina (1934) (Plate 4, Figure 18)}

Description: Simonsen and Kanaya (1961), p. 503-504, pl. 1, fig. 14-18; Schrader (1973b), p. 418-419, pl. 1, fig. 7, 8. Specimens close to Denticula kamtschatica are rare. The exact taxonomic position could not be classified up to now. It was also impossible to show if these individuals represent intact frustules or if they represent only girdle bands of unknown taxonomic affinity.

\section{Denticula lauta Bailey (1954)}

(Plate 4, Figures 10, 11, 13, 28)

Description: Simonsen and Kanaya (1961), p. 500-501, pl. 1, fig. 18, (non fig. 9, 10 "Denticula dimorpha" Schrader); Schrader (1973b), p. 419 , pl. 1, fig. $11,20,23,24$.

\section{Denticula lauta var. ovata Schrader var. nov.}

(Plate 4, Figure 7)

Description: Differs from the species by having more elliptical valves and a more coarse structure. Valves strongly silicified, elliptical with broadly rounded ends $25-35 \mu \mathrm{m}$ long, $11-13 \mu \mathrm{m}$ wide with a mean length to width ratio of 2.6 (whereas Denticula lauta has a mean length to width ratio of 4.1). Pseudoseptae approx. $4-5$ in $10 \mu \mathrm{m}$. Transapical striae 12 in $10 \mu \mathrm{m}$, punctate. Punctae in decussate arrangement, forming oblique rows.

Discussion: This variety is close to Denticula hustedtii var. ovato Schrader var. nov., but differs by the absence of secondary pseudoseptae.

Holotype: Plate 4, Figure 7 from DSDP Leg 29, Sample 278-13-1, 50-51 cm, southwest Pacific.

\section{Denticula nicobarica Grunow (1868)}

(Plate 4, Figures 19-21)

Description: Simonsen and Kanaya (1961), p. 503, pl. 1, fig. 11-13; Schrader (1973b), p. 419-420, pl. 1, fig. 25-27. McCollum (1975) has partly combined Denticula nicobarica Grunow with a true Nitzschia, described here as Nitzschia maleinterpretaria. For further remarks see this. On the other hand, this species is frequently combined with Denticula punctata and thus the geological range differs from that of Schrader (1973b); both species are easily distinguished following the original description.

\section{Denticula punctata Schrader (1973a)}

$$
\text { (Plate 4, Figure 16) }
$$

Description: Schrader (1973a), p. 705, pl. 1, fig. 25-30; pl. 3, fig. 16, 17; Schrader (1973b), p. 420, pl. 1, fig. 19.

\section{Denticula punctata var. hustedtii Schrader (1973a)}

$$
\text { (No illustration) }
$$

Description: Schrader (1973a), p. 705, pl. 1, fig. 23-24; Schrader (1973b), p. 420 , pl. 1, fig. 18

\section{Denticula aff. seminae (Semina) Simonsen and Kanaya (1961)} (No illustration)

Description: Simonsen and Kanaya (1961), p. 503, pl. 1, fig. 26-30; Schrader (1973b), p. 420, pl. 1, fig. 1-4. Specimens are close to Denticula hustedtii but with a structure not resolvable with a high power oil immersion of n.A. 1.4 in normal plane light. These individuals may represent aberrant forms of Denticula hustedtii, but are grouped separately here for biostratigraphic purpose. Denticula seminae has not yet been reported from the Antarctic and has been interpreted as being endemic to the North Pacific and Bering Sea.

Denticula sp. 1

(Plate 4, Figure 26)

\section{Genus DIPLONEIS Ehrenberg (1844)}

\section{Diploneis various species}

(No illustration)

All species encountered in Leg 35 sediment materials are derived from shallow water and are of benthonic-marine origin.

\section{Genus ETHMODISCUS Castracane (1886)}

\section{Ethmodiscus "rex" (Rattray) Hendey and Wiseman (1953) (No illustration)}

Description: Hendey and Wiseman (1953), p. 51-57, pl. 1, fig. 1-6; pl. 2, fig. 1-3. I have placed all Ethmodiscus fragments into this "group-species" even if it is almost impossible to identify Ethmodiscus species by fragments not having the central part of the valve represented.

\section{Genus EUCAMPIA Ehrenberg (1839)}

Eucampia balaustium Castracane (1886) (Plate 14, Figure 7)

Description: Castracane (1886), p. 97, pl. 18, fig. 5 remarks in Hustedt (1958), p. 136-137, pl. 5, fig. 40-43.

\section{Genus GONIOTHECIUM Ehrenberg (1841)}

Goniothecium odontella Ehrenberg (1844)

(Plate 14, Figures 5, 6)

Description: Karsten (1928), p. 301, fig. 419A.

Genus HEMIAULUS Ehrenberg (1844)

Hemiaulus cf. polymorphus Grunow (1884)

(No illustration)

Description: Hustedt (1930), p. 880-881, fig. 525, 526. Several specimens in the lower part of Site 278 resemble $H$. polymorphus; problems concerning the systematics of the genus Hemiaulus are not dealt with in this paper.

\section{Hemiaulus sp. 5 \\ (Plate 14, Figure 8) \\ Genus HEMIDISCUS Wallich (1860) \\ Hemidiscus karstenii Jousé (1962) \\ (Plate 14, Figure 2)}

Description: Abbott (1972), p. 110-112, pl. 1, fig. D-F Abbott (1972) suggested that this species be included, after thorough investigation, into Actinocyclus ellipticus, because of its elliptical shape. This assumption cannot be followed because Hemidiscus karstenii possesses the typical cuneate frustules in girdle view. This species is very close to Hemidiscus simplicissimus Hanna and Grant (1926) and differentiation is made here with hesitation. Differences are the eccentrical position of the pseudonodule and the coarser and more irregularly arranged structure on the valve surface. 


\section{Genus MACRORA Hanna (1932)}

This genus is definitely not a diatom as pointed out by Hanna (1932), but it can be used as a good guide fossil for Miocene sediments.

\section{Macrora stella (Azpeitia) Hanna (1932)}

(Plate 14, Figures 11, 12)

Description: Hanna (1932), p. 196, pl. 12, fig. 7.

Genus MEDIARIA Sheshukova-Poretzkaya (1962)

Mediaria splendida Sheshukova-Poretzkaya (1962) (No illustration)

Description: Sheshukova-Poretzkaya (1967), p. 306, pl. 47, fig. 14; pl. 48 , fig. 8 .

\section{Genus MELOSIRA Agardh (1824)}

Melosira sulcata (Ehrenberg) Kützing (1844)

(No illustration)

Description: Hustedt (1930), p. 276-278, fig. 118-120.

Genus NAVICULA Bory (1824)

Navicula sp. 1

(Plate 5, Figure 10)

Only fragments were found. No similar species was reported in the literature.

\section{Genus NITZSCHIA Hassal (1845)}

\section{Nitzschia angulata Hasle (1972)}

$$
\text { (No illustration) }
$$

Synonyms: Diatoma rhombica O'Meara (1877), p. 55, pl. 1, fig. 2; Fragilariopsis rhombica (O'Meara) Hustedt (1952), p. 296, fig. 6, 7.

Description: Hasle (1965), p. 24-26, pl. 1, fig. 6; pl. 4, fig. 19; pl. 6, fig. 5; pl. 8, fig. 11 ; pl. 9, fig. 1-6; pl. 10, fig. 2-6.

\section{Nitzschia claviceps sp. nov.}

(Plate 2, Figures 2, 4)

Description: Valves club-like with broadly rounded apices, 37-45 $\mu \mathrm{m}$ long, smallest width 6-7, broadest width 9-10 $\mu \mathrm{m}$. Apical axis heteropol. Transapical costae straight in the middle of the valves, 7-8 in $10 \mu \mathrm{m}$, becoming curved towards the apices. One apex with curved transapical costae with a curving center near the apical axis, the other with a curving center eccentrically neighbored towards the raphe. Intercostal membranes with two lines of decussate distinct pores, approx. 19 in $10 \mu \mathrm{m}$. Raphe marginal.

Discussion: No similar species has been found in the literature.

Holotype: Plate 2, Figure 2, from DSDP Leg 29, Sample 278-11-1, $50-51 \mathrm{~cm}$, southwest Pacific.

Paratype: Plate 2, Figure 4.

\section{Nitzschia curta (Van Heurck) Hasle (1972)}

(Plate 15, Figures 21, 23, 24)

Synonym: Fragilariopsis curta (Heurck) Hustedt in Hasle (1965), p. $32-33$, pl. 6, fig. 6 ; pl. 12, fig. $2-5$; pl. 13, fig. 1-6; pl. 16, fig. 6 ; pl. 17, fig. 5 .

\section{Nitzschia cylindrus (Grun.) Hasle (1972) (No illustration)}

Description: Hasle (1965), p. 34-37, pl. 12, fig. 6-12; pl. 14, fig. 110; pl. 17 , fig. $2-4$.

\section{Nitzschia denticuloides sp. nov.}

(Plate 3, Figures 7, 8, 10, 12, 18-24; Plate 15, Figure 22)

Description: Valves elliptical with broadly rounded ends to valves with parallel margins with slightly capitate apices, 70-28 $\mu \mathrm{m}$ long, 13$8 \mu \mathrm{m}$ wide. Valves strongly silicified with a lanceolate hyaline middle area to a narrow hyaline area. Area in some specimens with a continuation of the transapical ribs, in some without. Sometimes pores scattered or have an apical pore line. Transapical ribs straight in the middle of the valves, curved towards the poles and continuing over the apex with radial arranged short ribs, 6-7 in $10 \mu \mathrm{m}$. Transapical ribs forming transapical chambers with a hyaline outer membrane and a wide pore opening to the inner side. Valve structure very variable. Raphe marginal, canal raphe with keel punctae, 6-7 in 10 $\mu \mathrm{m}$.

Discussion: This species is very close to Denticula antarctica McCollum, but differs by the valve outline and the interrupted transapical ribs. No similar species was found in the literature. It is still questionable whether McCollum (1975), in including these specimens with Denticula antarctica, established a different range. There is a wide variation and in cases it seemed difficult to separate between $D$. antarctica and this species.

Holotype: Plate 3, Figures 21, 22, from DSDP Leg 29. Sample 27811-1, 50-51 cm, southwest Pacific.

Paratype: Plate 3, Figure 18.

\section{Nitzschia donahuensis sp. nov.}

(Plate 2, Figure 30)

Description: Valve broadly lanceolate with heteropol apical axis, and acute rounded apices, $45-55 \mu \mathrm{m}$ long, $10-13 \mu \mathrm{m}$ wide, length and width positively correlated. Transapical costae straight; slightly curved to curved near and on the apices, 5-6 in $10 \mu \mathrm{m}$. Intercostal membranes poroid with one line of small slot-like pores, approx. 20 in 10 $\mu \mathrm{m}$. Raphe marginal, keel punctae 5-6 in $10 \mu \mathrm{m}$, transapical ribs seem to be widened towards the raphe canal.

Discussion: This species is close to Nitzschia (Fragilariopsis) lanceolata Donahue (1970, p. 208, pl. 7, fig. m-p) but differs by the much finer slot-like structure of the intercostal membranes.

Derivation of name: To Dr. J. Donahue, who initiated detailed biostratigraphic investigation of Quaternary Antarctic siliceous sediments.

Holotype: Plate 2, Figure 30, from DSDP Leg 29, Sample 278-14. $1,50-51 \mathrm{~cm}$, southwest Pacific.

Nitzschia efferans sp. nov.

(Plate 2, Figures 1, 3, 5-7)

Description: Valve club-like to elliptical with semiparallel margins, broadly rounded apices, 26-54 $\mu \mathrm{m}$ long, smallest width 4-6 $\mu \mathrm{m}$, broadest width $7-10 \mu \mathrm{m}$. Apical axis heteropol. Transapical ribs well developed only near the margins, 6-7 in $10 \mu \mathrm{m}$, straight in the middle of the valve, slightly curved to strongly curved near the apices. Center of curving on one apex in the valve apical axis, of the other broader apex, eccentrically. Intercostal membranes with one line of large pores, sometimes irregularly arranged, approx. 5 in $10 \mu \mathrm{m}$ when complete. One large pore on each margin in between the distinct transapical ribs. Raphe marginal.

Discussion: This species differs from $N$. claviceps by the coarser structure. No similar species has been observed in the literature.

Holotype: Plate 2, Figure 1, from DSDP Leg 29, Sample 278-17-1, $50-51 \mathrm{~cm}$, southwest Pacific.

Paratype: Plate 2, Figure 5.

\section{Nitzschia evenescens sp. nov.}

(Plate 2, Figures 22, 23)

Description: Valves linear-elliptical with broadly rounded ends, 25-30 $\mu \mathrm{m}$ long, 6-4 $\mu \mathrm{m}$ wide. Apical axis isopolar. Transapical ribs $14-$ 15 in $10 \mu \mathrm{m}$, straight in the middle of the valves, slightly curved near the apices. Intercostal membranes punctate, punctae closely spaced, often melted into one another, $20-22$ in $10 \mu \mathrm{m}$. Raphe marginal, keel punctae marginal, approx. $14-15$ in $10 \mu \mathrm{m}$, no pseudonodulus present.

Discussion: This species is close to Nitzschia maleinterpretaria, but differs from it by the finer structure. No similar species was found in the literature.

Holotype: Plate 2, Figure 22 from DSDP Leg 29, Sample 278-17-1, $50-51 \mathrm{~cm}$, southwest Pacific.

Paratype: Plate 2, Figure 23.

\section{Nitzschia grossepunctata sp. nov. (Plate 3, Figures 1-4)}

Synonym: Rhaphoneis sp., McCollum (1975), pl. 11, fig. 9, 10. Description: Valves elliptical with broadly rounded ends, sometimes broadly capitate, $46-40 \mu \mathrm{m}$ long, 9-7 $\mu \mathrm{m}$ wide. Transapical ribs 8 in $10 \mu \mathrm{m}$ distinctly marked only at the margins. Valve surface with 
"intercostal membranes" coarsely punctate (pores 1.7-1 $\mu \mathrm{m}$ in diameter) with one line of large punctae, which are reduced in some individuals, on both sides of the margins and one line of large pores in between the transapical ribs. Transapical ribs radial and continuing over the apices. Raphe marginal with distinct keel punctae, 8 in 10 $\mu \mathrm{m}$, raphe bent towards the apices onto the valve surface. Pseudonodulus present in most individuals, slightly enlarged, and distinguished from other keel punctae by being close to one apex.

Discussion: No similar species was found in the literature. It is different from all other Nitzschia species by the coarse punctate structure.

Holotype: Plate 3, Figures 3, 4, from DSDP Leg 29, Sample 27820-2, 60-61 cm, southwest Pacific.

Paratype: Plate 3, Figures 1, 2.

\section{Nitzschia interfrigidaria McCollum (1975) (No illustration)}

Description: McCollum (1975), pl. 9, fig. 7-9. In order to clear the exact taxonomic position and the variation of this species a detailed reinvestigation of DSDP Leg 28 material seems necessary. This is not possible at present. This species is close to Nitzschia grossepunctata sp. nov. I did follow the illustration of McCollum due to incomplete diagnosis. Thus all individuals close to McCollum's pictures are designated here as affinis: Nitzschia aff. interfrigidaria McCollum (1975, pl. 3, fig. 5, 6).

\section{Nitzschia januaria sp. nov.}

(Plate 2, Figures 25-29)

Description: Valves elliptical with broadly rounded ends, $15-30 \mu \mathrm{m}$ long, $7-5 \mu \mathrm{m}$ wide. Transapical costae straight in the middle of the valves, curved near the apices. Costae near the poles grading into apical direction, both pole field similarly structured; 13-12 costae in $10 \mu \mathrm{m}$. Intercostal membranes hyaline in normal plane through light. Keel punctae in some specimens distinct, approx. 12 in $10 \mu \mathrm{m}$ with no indication of a pseudonodulus. Raphe marginal.

Discussion: This species differs from other Nitzschia species by its isopol valves, the identical structure of the pole fields and the valve shape, no similar species were observed in the literature.

Holotype: Plate 2, Figure 26, from DSDP Leg 29, Sample 278-11-

$1,50-51 \mathrm{~cm}$, southwest Pacific.

Paratype: Plate 2, Figure 25.

\section{Nitzschia kerguelensis (O'Meara) Hasle (1972) (No illustration)}

Description: Hasle (1965), p. 14-18, pl. 3, fig. 4, 5; pl. 4, fig. 11-18; pl. 5, fig. 1-11; pl. 6, fig. 2-4; pl. 7, fig. 9; pl. 8, fig. 10; pl. 16, fig. 3-5.

\section{Nitzschia maleinterpretaria sp. nov.}

(Plate 2, Figures 9, 11-19, 21, 24)

Description: Valves elliptical to linear elliptical with broadly rounded apices, 43-1I $\mu \mathrm{m}$ long, 7-3 $\mu \mathrm{m}$ wide. Apical axis isopol. Transapical ribs $12-13$ in $10 \mu \mathrm{m}$, straight in the middle of the valves, becoming curved towards the apices, one apex with slightly curved, the other one with strongly eccentrically curved ribs. Intercostal membranes with one line of round distinct pores, sometimes incomplete with omitted pores, approx. 10 in $10 \mu \mathrm{m}$. Raphe marginal, keel punctae sometimes visible, approx. 12 in $10 \mu \mathrm{m}$.

Discussion: This species is very close to Denticula nicobarica and may be misinterpreted occasionally. It differs from those forms by the absence of pseudoseptae.

Holotype: Plate 2, Figure 9, from DSDP Leg 29, Sample 278-24-1, $50-51 \mathrm{~cm}$, southwest Pacific.

Paratype: Plate 2, Figure 12.

\section{Nitzschia porteri Frenguelli (1949)}

(Plate 2, Figures 33-35)

Description: Frenguelli (1949), p. 116, pl. 1, fig. 33, 34.

\section{Nitzschia aff. porteri Frenguelli (1949)} (Plate 2, Figure 32)

Description: Frenguelli (1949), p. 116, pl. 1, fig. 33, 34. Atypical specimen with similar structure, but differs by the narrow elongated valve shape.

\section{Nitzschia praeinterfrigidaria McCollum (1975)}

$$
\text { (No illustration) }
$$

Description: McCollum (1975), pl. 10, fig. 1. The illustration of McCollum (1975) has been used to identify this species. The variation, taxonomy, and morphology still needs to be correlated with DSDP Leg 29 type material.

\section{Nitzschia pseudokerguelensis sp. nov. \\ (Plate 15, Figures 13-15)}

Description: Valves broadly lanceolate with a heteropol apical axis, with one pole broadly rounded and the other acute, $52-40 \mu \mathrm{m}$ long, $11-10 \mu \mathrm{m}$ wide. Frustules strongly silicified and coarsely structured, 6 transapical costae in $10 \mu \mathrm{m}$. Transapical ribs are straight in the middle of the valves and curved towards the poles. Intercostal membrane distinctly punctate with one row of large poroids. Keel punctae distinct 6 in $10 \mu \mathrm{m}$, canal raphe distinct.

Discussion: This species is close to Nitzschia kerguelensis (O'Meara) Hasle in Hasle (1965), p. 14-16, numerous figures, but differs by the intercostal membranes with only one line of poroids, by the canal raphe, and the keel punctae.

Holotype: Plate 15, Figures 14, 15, from DSDP Leg 29, Sample 278-16-4, 50-51 cm, southwest Pacific.

Paratype: Plate 15, Figure 13.

\section{Nitzschia pusilla sp. nov. \\ (Plate 2, Figure 20)}

Description: Valves elliptical to linear elliptical with broadly rounded apices, 20-27 $\mu \mathrm{m}$ long, 5-6 $\mu \mathrm{m}$ wide. Apical axis isopol. Transapical ribs straight in the middle of the valves, curved near the apices, $16-17$ in $10 \mu \mathrm{m}$. Intercostal membranes punctate, punctae closely spaced, approx. 22-24 in $10 \mu \mathrm{m}$. Raphe marginal, 15-16 in 10 $\mu \mathrm{m}$ keel punctae, no pseudonodulus present.

Discussion: This species is close to Nitzschia maleinterpretaria but has finer structure. No similar species was found in the literature.

Holotype: Plate 2, Figure 20, from DSDP Leg 29, Sample 278-211, 50-51 cm, southwest Pacific.

\section{Nitzschia ritscheri (Hustedt) Hasle (1972) (No illustration)}

Description: Hasle (1965), p. 20-21, pl. 1, fig. 20; pl. 3, fig. 3; pl. 4, fig. $1-10$; pl. 5 , fig. 12,13 ; pl. 6 , fig. 1 ; pl. 7 , fig. 8 .

$$
\begin{gathered}
\text { Nitzschia separanda (Hustedt) Hasle (1972) } \\
\text { (No illustration) }
\end{gathered}
$$

Description: Hasle (1965), p. 26-27, pl. 9, fig. 7-10; pl. 10, fig. 1.

\section{Nitzschia sicula var. rostrata Hustedt (1958)}

(Plate 2, Figure 31)

Description: Hustedt (1958), p. 180, pl. 11, fig. 128-132; Hasle (1964), p. 39-41, pl. 14, fig. 22; pl. 16, fig. $2,4$.

Nitzschia sp. 14

(Plate 2, Figures 8, 36)

$$
\begin{aligned}
& \text { Nitzschia sp. } 16 \\
& \text { (Plate 2, Figure } 37 \text { ) }
\end{aligned}
$$

\section{Nitzschia sp. 17}

(Plate 3, Figures 13-15, 17; Plate 2, Figure 10)

The morphological variation within this artificial grouping is not understood at the moment by the author. Therefore a number of extremes are pictured to demonstrate variations. Pictured individuals may later prove to belong to more than one species, others may be evolutionary lineages.

Nitzschia sp. 18

(Plate 15, Figure 19)

Nitzschia sp. 19

(Plate 15, Figure 20) 
Genus PINNULARIA Ehrenberg (1840)

Pinnularia nobilis Ehrenberg

(No illustration)

Description: Hustedt (1930), p. 337, fig. 619.

Genus PTEROTHECA (Grunow) Forti (1909)

Pterotheca sp. 1

(Plate 14, Figure 10)

Genus PYRGUPYXIS Hendey (1869)

Pyrgupyxis johnsoniana Greville (Hendey, 1865)

(No illustration)

Description: Greville (1865), p. 2, pl. 1, fig. 6.

Pyrgupyxis prolungata Brun (Hendey, 1891)

(No illustration)

Description: Brun (1891), p. 176, pl. 24, fig. 7.

Genus RAPHIDODISCUS H.L. Smith (1887)

Raphidodiscus marylandicus Christian (1887)

(Plate 5, Figure 19; Plate 15, Figure 16)

Description: Andrews (1973, 1974), p. 233-234, pl. 1-5.

Genus RHAPHONEIS Ehrenberg (1844)

Rhaphoneis sp. 1

(Plate 14, Figure 13)

Only one fragment was found; therefore no taxonomic study was made. Similar species were not observed in the literature.

\section{Genus RHIZOSOLENIA Ehrenberg (1841)}

Rhizosolenia alata Brightwell (1858)

(Plate 9, Figure 10)

Description: Hustedt (1930), p. 600-604, fig. 345-348.

Rhizosolenia barboi Brun (1894)

(Plate 9, Figures 11-13)

Description: Donahue (1970), p. 136.

Rhizosolenia hebetata forma hiemalis Grun (1904)

(Plate 9, Figure 3)

Description: Hustedt (1930), p. 590-592, fig. 337.

\section{Rhizosolenia hebetata f. hiemalis-spinosa}

(Plate 9, Figures 1, 2)

Differs from the above-mentioned forma by its longer spine. Structure on the calyptra somewhat finer than on the forma. At present no new variety or species will be established with these forms unless the taxonomy of $R$. hebetata has been cleared.

\section{Rhizosolenia minima sp. nov.}

(Plate 15, Figures 1-3)

Description: Valve cylindrical, widened at the base, tapering towards the apex, apical process round, small with radial punctate lines, approx. 10 in $10 \mu \mathrm{m}$, punctate lines reaching the end of apical process. Apical process with spine at the top. Spine tapers towards the top, but is mostly broken off. Individuals found are $30-23 \mu \mathrm{m}$ long, apical process approx. $6-3 \mu \mathrm{m}$ in diameter.

Discussion: No similar species were observed in the literature. Individuals are mostly broken, but are easily identified by their small size.

Holotype: Plate 15, Figures 2, 3, from DSDP Leg 29, Sample 27814-1, 50-51 cm, southwest Pacific.

Paratype: Plate 15, Figure 1.
Rhizosolenia oligocaenica sp. nov.

(Plate 9, Figure 7)

Description: Valve cylindrical, approx. $14 \mu \mathrm{m}$ in diameter at base, tapering gradually towards the apex. Apical process round with radial punctate lines, about 23 in $10 \mu \mathrm{m}$, punctae forming oblique rows, distance between oblique rows little wider than between radial rows. Punctate structure not reaching end of apex. Apical process with apical spine at the top. Spine tapers towards the top, with a small central canal.

Discussion: No similar species has been observed in the literature. This species can easily be distinguished from others by its range and by its fine structure.

Holotype: Plate 9, Figure 7, from DSDP Leg 29, Sample 278-32-4, $120-121 \mathrm{~cm}$, southwest Pacific.

$$
\begin{gathered}
\text { Rhizosolenia praebarboi Schrader (1973a) } \\
\text { (Plate 9, Figure 14) }
\end{gathered}
$$

Description: Schrader (1973a), p. 709-710, pl. 24, fig. 1-3.

$$
\text { Rhizosolenia styliformis Brightwell (1858) }
$$

(Plate 9, Figure 4)

Description: Hustedt (1930), p. 584-588, fig. 333-335.

\section{Rhizosolenia sp. 1}

(Plate 9, Figure 5)

These specimens may be included into $R$. styliformis but differ by the complexly built wings surrounding the spine.

Rhizosolenia sp. 2

(Plate 9, Figure 6)

This specimen is similar to $R$. minima, but differs by having a coarser structure and a different range.

\section{Genus ROPERIA Grunow in Van Heurck (1881)}

Roperia tesselata (Roper) Grunow in Van Heurck (1881)

(No illustration)

Description: Hustedt (1930), p. 523-524, fig. 297.

Genus ROUXIA Brun and Héribaud (1893)

Rouxia antarctica Heiden and Kolbe (1928)

(Plate 5, Figures 1-8)

Description: Heiden and Kolbe (1928), p. 632, pl. 4, fig. 90.

Rouxia californica M. Peragallo in Tèmpère and Peragallo (1910) (Plate 5, Figure 21)

Description: Hanna (1930), p. 186-188, pl. 14, fig. 6, 7.

\section{Rouxia elongata sp. nov.}

(Plate 15, Figures 4, 5)

Description: Valves linear with rounded rostrated apices, and swelled up central parts, 200-230 $\mu$ m long, $8 \mu$ m wide in the middle, 6 $\mu \mathrm{m}$ wide between center and apex. Valve surface convex with a central depression. Raphe bars well developed, with a rectangular, narrow central area and narrow apical areas. Transapical striae 15 in $10 \mu \mathrm{m}$ transapical-parallel, becoming radial at the very apex. Transapical striae with punctae 2-4 within one striae. Inner pores near the margins. Pole fields with a sharp triangular hyaline area, isopol.

Discussion: This species differs from all other Rouxia species by its elongated valve, by its long raphe bars and by its fine structure.

Holotype: Plate 15, Figures 4, 5, from DSDP Leg 29, Sample 27820-6, 50-51 cm, southwest Pacific.

Rouxia isopolica sp. nov.

(Plate 5, Figures 9, 14, 15, 20)

Description: Valves linear-lanceolate with cuneate broadly rounded ends 21-48 $\mu \mathrm{m}$ long, 4-6 $\mu \mathrm{m}$ wide. Valve surface flat with a central depression over the central area. Two rudimentary raphe bars separated by an elongated narrow hyaline central area. Axial area narrow, parallel to the raphe. Transapical striae $18-19$ in $10 \mu \mathrm{m}$, transapical becoming radiate near the apices. Striae crossed by two 
apical lines, one very near the margin, the other one between margin and apical axis. Transapical striae with one to two inner pores. Pole fields hyaline, triangular, isopol.

Discussion: Differs from other Rouxia species by its fine structure and by its triangular hyaline pole fields.

Holotype: Plate 5, Figure 15, from DSDP Leg 29, Sample 278-11$1,50-51 \mathrm{~cm}$, southwest Pacific.

Paratype: Plate 5, Figures 9, 14, 20.

\section{Rouxia naviculoides Schrader (1973a)}

(Plate 5, Figures 13, 18)

Description: Schrader (1973a), p. 710, pl. 3, fig. 27-32.

\section{Rouxia oligocaenica sp. nov.}

(No illustration)

Synonyms: Rouxia peragalli Abbott non Brun and Héribaud in Abbott (1972), pl. 9; fig. A; Rouxia peragalli McCollum non Brun and Héribaud in McCollum (1975), pl. 12, fig. 1, 2.

Description: Valves elliptical with broadly rounded ends $30-55 \mu \mathrm{m}$ long, $15-20 \mu \mathrm{m}$ wide. Valve surface flat, two rudimentary raphe bars separated by a narrow central area. Transapical striae 5 in $10 \mu \mathrm{m}$, parallel becoming radial towards the apices. Striae crossed by one apical line somewhat parallel to the margin. Transapical striae representing chambers with no visible structure in light microscope. Valve structure isopolar.

Discussion: This species differs from other Rouxia species by its coarse structure, by its isopolar valve structures, and by its geological range. Specimens found in Pliocene to Pleistocene sediment materials are reworked from older strata.

Holotype: McCollum (1975), pl. 12, fig. 1, from DSDP Leg 28, Sample 274-11-1, 140-142 cm, South Pacific.

\section{Rouxia yabei Hanna $(1930$}

(No illustration)

Description: Hanna (1930), p. 185, pl. 15, fig. 2-4.

Rouxia sp. 2

(Plate 5, Figures 11, 12)

\section{Genus STEPHANOPYXIS Ehrenberg (1844)}

\section{Stephanopyxis "turris" (Grev. and Arn.) Ralfs in Pritchard (1861) (Plate 13, Figure 7)}

Description: Hustedt (1930), p. 304-307, fig. 140-144. All individuals belonging to the genus Stephanopyxis have been grouped into this "group species." At the moment I am unable to distinguish and separate the variously described Stephanopyxis species of Miocene to Eocene age. Separation by the arrangement of spines and marginal areas seems to be more satisfactory and must be reviewed to enable workers to distinguish and work with species of this genus for stratigraphic purposes.

\section{Genus SYNEDRA Ehrenberg (1830)}

Synedra jouseana Sheshukova-Poretzkaya (1962) (Plate 1, Figures 11-13)

Description: Sheshukova-Poretzkaya (1967), p. 245; Schrader (1973a), p. 710, pl. 23, fig. 21-23, 25, 28.

\section{Synedra miocenica sp. nov.}

(Plate 1, Figure 1)

Diagnosis: Valves narrow with parallel margins, $7-10 \mu \mathrm{m}$ wide, 250-300 $\mu \mathrm{m}$ long. Ends broadly rounded, transapical striate marginal, with a wide pseudoraphe, $15-17$ in $10 \mu \mathrm{m}$. Axial area wide, lanceolate. Poles isopol with isolated elongated mucilage pores on each side.

Discussion: This species differs from Synedra jouseana by its parallel margin, by the different shape of the poles, and by the different mucilage pores. No similar species has been observed in the literature.

Holotype: Plate 1, Figure 1 (total), fig. 1a and $1 \mathrm{~b}$ from DSDP Leg 29. Sample 278-13-1, 50-51 cm, southwest Pacific.

\section{Synedra ulna (Nitzsch) Ehrenberg}

(No illustration)

Description: Hustedt (1932), p. 151-154, fig. 158-168.

Genus THALASSIONEMA Grunow (1881)

Thalassionema hirosakiensis (Kanaya) Schrader (1973a)

(? Plate 1, Figures 14-16)

Description: Kanaya (1959), p. 104-106, pl. 9, fig. $11-15$ as Fragilaria hirosakiensis.

Thalassionema nitzschioides Grunow in Van Heurck (1881) (No illustration)

Description: Hustedt (1959), p. 244-246, fig. 725.

$$
\text { Genus THALASSIOSIRA Cleve (1873) }
$$

Thalassiosira convexa var. aspinosa Schrader (1974)

(Plate 15, Figures 9, 10)

Description: Schrader (1974), p. 916, pl. 2, fig. 8, 9, 13a-21.

Thalassiosira cf. decipiens (Grunow) Jörgensen (1905)

(No illustration)

Description: Hustedt (1930), p. 322-323, fig. 158.

Thalassiosira gracilis (Karsten) Hustedt (1958)

(No illustration)

Description: Hustedt (1958), p. 109, fig. 4-7.

Thalassiosira nativa Sheshukova-Poretzkaya (1964) (Plate 12, Figures 8-11)

Description: Sheshukova-Poretzkaya (1967), p. 145, pl. 14, fig. 7.

Thalassiosira oestrupii (Ostenfeld) Proshkina-Lavrenko (1953) (No illustration)

Description: Hustedt (1930), p. 318 , fig. 155 as Coscinosira oestrupii.

Thalassiosira spinosa sp. nov.

(Plate 6, Figures 5-7)

Description: Valve strongly convex, $18-20 \mu \mathrm{m}$ in diameter. Areolae hexagonal forming closed network over the entire valve, 9-10 in 10 $\mu \mathrm{m}$, decreasing in size gradually towards the margin. Areolae in radial rows, sometimes fasciculate or arranged in convex lines. Margin 1-1.5 $\mu \mathrm{m}$ wide with radial striae 10 in $10 \mu \mathrm{m}$. One row of heavily silicified spines near the margin, spines mostly broken off, but detectable by the base.

Discussion: This species is almost identical with the Pliocene marker species, $T$. convexa, but differs by its geological range, by the more robust spines, and by the finer areolation.

Holotype: Plate 6, Figure 6, from DSDP Leg 29, Sample 278-27-1, $50-51 \mathrm{~cm}$, southwest Pacific.

Paratype: Plate 6, Figures 5, 7.

\section{Thalassiosira spinosa var. aspinosa var. nov.} (Plate 6, Figure 3)

Description: This variety differs from the species by its nonspinous margin; other morphological criteria are almost identical with $T$. spinosa.

Holotype: Plate 6, Figure 3, from DSDP Leg 29, Sample 278-27-1, $50-51 \mathrm{~cm}$, southwest Pacific.

Thalassiosira spumellaroides sp. nov. (Plate 6, Figures 1, 2)

Description: Cells solitary, appearance similar to a spumellarian radiolarian, valves $40-60 \mu \mathrm{m}$ in diameter, convex with a flattened central part. Valve margin finely striated. Areolae, hexagonal, arranged in tangential rows, approx. 6 areolae in $10 \mu \mathrm{m}$, slightly decreasing in size towards the margin. No central area. Long strongly silicified species do arise near the margin. No labiate process nor strutted tubuli were found in these strongly silicified frustules. 
Discussion: No similar species was found in the literature, it grades towards Thalassiosira convexa, and this was one of the reasons for its position in the genus Thalassiosira.

Holotype: Plate 6, Figures 1, 2, from DSDP Leg 29, Sample 27825-1, 100-101 cm, southwest Pacific.

Thalassiosira sp. 8

(Plate 12, Figure 12)

Thalassiosira sp. 9

(Plate 13, Figures 4a-4b; Plate 15, Figures 11, 12)

Thalassiosira sp. 10

(Plate 15, Figures 6-8)

Genus THALASSIOTHRIX Cleve and Grunow (1880)

Thalassiothrix frauenfeldii (Grunow) Grunow

in Cleve and Grunow (1880)

(Plate 1, Figures 7-10)

Description: Hustedt (1959), p. 247-248, fig. 727; Hasle and Mendiola (1967), p. 113-114, fig. 9, 10, 21, 38, 47-52.

Thalassiothrix longissima Cleve and Grunow (1880)

(Plate 1, Figures 5, 6, 17)

Description: Hustedt (1959), p. 247, fig. 726; Hasle and Mendiola (1967), p. 114, fig. 35-37, 45, 46, 53. All Thalassiothrix individuals have been grouped within this species, which possess dissimilar ends, one end is somewhat widened and bluntly rounded, the other has a swallowtail-like spine. The marginal spines are mostly broken off.

Thalassiothrix monospina Schrader (1974)

(No illustration)

Description: Schrader (1974a), p. 917, pl. 19, fig. 9, 10.

Thalassiothrix primitiva sp. nov.

(Plate 1, Figure 3)

Description: Valves strongly silicified, elongate linear with parallel margins and broadly rounded apices, mostly broken into fragments, complete frustules 200-400 $\mu \mathrm{m}$ long, 9-12 $\mu \mathrm{m}$ wide. Ends dissimilar, one of them broadly rounded with a rounded mucilage pore and a solitary, rudimentary spine and continuation of the transapical structures which are here radially oriented, the other one with a more acute end and a solitary elliptical mucous pore. Marginal punctae approx. 13 in $10 \mu \mathrm{m}$.

Discussion: This species differs from others by the strongly silicified valves and by the apices. No similar species were found in the literature.

Holotype: Plate 1, Figure 2 from DSDP Leg 29, Sample 278-32-6, 50-51 cm, southwest Pacific. Schrader Collection.

Paratype: Plate 1, Figure 3. Schrader Collection.

Thalassiothrix vanhoeffenii Heiden in Heiden and Kolbe (1928) (No illustration)

Description: Heiden in Heiden and Kolbe (1928), p. 566, pl. 6, fig. 124, 125; Simonsen (1974), p. 38, pl. 25, fig. 1-3. This species was distinguished from Thalassiothrix longissima by its broad transapical striae, approx. 8 in $10 \mu \mathrm{m}$, whereas T. longissima has approx. 20-24 in $10 \mu \mathrm{m}$.

Genus TRINACRIA Heiberg (1863)

Trinacria excavata Heiberg (1863)

(Plate 14, Figure 15)

Description: Hustedt (1930), p. 887-888, fig. 532.

Trinacria pileolus (Ehr.) Grunow (1884) (No illustration)

Description: Hustedt (1930), p. 885-887, fig. 529.
Genus XANTHIOPYXIS Ehrenberg (1844)

Xanthiopyxis oblonga Ehrenberg (1844)

(Plate 14, Figure 4)

Description: Hanna (1927), p. 124.

\section{Genus et species indet. \\ (Plate 5, Figure 16)}

Genus et species indet.

(Plate 12, Figure 14)

\section{ACKNOWLEDGMENTS}

This investigation was supported by the Deutsche Forschungsgemeinschaft. The help of Mrs. Schmidtmann and Mrs. Riefer in typing is gratefully acknowledged. Discussions with Peter Richert, Juliane Fenner, and fellow scientists aboard Glomar Challenger provided scientific advice. Paula Worstell helped in all style and publication problems.

\section{REFERENCES}

Abbott, W.H., 1972. Vertical and lateral patterns of diatomaceous ooze found between Australia and Antarctica: Ph.D. Thesis, Department Geology, University of South Carolina. 1974. Observations on Pleistocene diatoms from the southeast Indian Ocean: Symp. Marine Plankton and Sediments, Kiel, Abstracts, p. 4.

in press. Temporal and spatial distribution of Pleistocene diatoms from the southeast Indian Ocean: Nova Hedw.

Agardh, C.A., 1824. Systema Algarum: Adumbravit C.A. Agardh. Literis Berlingianis (Lundae) XXVII. , 1830. Conspectus criticus Diatomacearum: (Lundae), v. 1, p. 1.

1832. Conspectus criticus Diatomacearum: (Lundae), v. 4, p. 48.

Andrews, G., 1974. Systematic position and stratigraphic significance of the marine diatom Raphidodiscus marylandicus Christian: Nova Hedw. Beihft., v. 45, p. 231-250.

Bailey, J.W., 1854. Notes on new species and localities of microscopical organisms: Smithsonian Inst., Contrib. Knowl., v. 7, p. 1-15.

Balech, E., El-Sayed, S.Z., Hasle, G.R., Neushul, M., and Zaneveld, J.S., 1968. Primary production and benthic marine algae of the Antarctic and Subantarctic: Antarctic Map Folio Ser., Folio 10, Am. Geogr. Soc.

Berggren, W.A., 1969. Cenozoic chronostratigraphy, planktonic foraminiferal zonation and the radiometric time scale: Nature, v. 224, p. 1072.

1972. A Cenozoic time scale-some implications for regional geology and paleobiogeography: Lethaia, v. 5 , p. 195 .

Bory de Saint-Vincent, J.B.M., 1824. Encyclopedie Methodique Histoire Naturelles des Zoophytes ou Animaux Rayonnés: Tom. 2, Paris (Agasse).

Brightwell, T., 1858. Remarks on the genus "Rhizosolenia" of Ehrenberg: Quart. J. Micr. Sci., v. 6, p. 93.

Brun, J., 1891. Notes sur quelques espèces nouvelles: Le diatomiste, v. 1, p. 173-177.

1894. Espèces nouvelles: Le diatomiste, v. 2, p. 72.

Brun, J. and Tempère, J., 1889. Diatomèes Fossiles du Japan. Espèces Marines et Nouvelles des Calcaires Argileux de Sandai et de Yendo: Mém. Soc. Phys. d'Hist. Nat. Genève, v. 30 .

Burckle, L.H., 1969. Late Cenozoic planktonic diatom zones in equatorial Pacific sediments (abstract): Geol. Soc. Am. Abs. v. 7, p. 24. 
1972. Late Cenozoic planktonic diatom zones from the eastern equatorial Pacific: Nova Hedw., Beihft., v. 39, p. 217.

, 1974. The distribution of displaced Antarctic diatoms in the Argentine Basin (abstract): Symp. Marine Plankton and Sediments, Kiel, Abstracts, p. 14.

Castracane, C.A.F.A., 1886. Report on the scientific results of the voyage of H.M.S. Challenger during the years 18731876: Botany, v. 2, p. 1-178.

Christian, T,, 1887. New diatomaceous deposits: The microscope, v. 7, p. 65.

Cita, B.M., 1972. The Miocene/Pliocene boundary history and definition. In Symposium on late Neogene epoch boundaries: XXIV Intern. Geol. Congress (Micropaleontology Press).

Cleve, P.T., 1873. Examination of diatoms found on the surface of the Sea of Java: Bihang. Svensk. Vetensk. Akad. Handl, v. 11 , p. 1.

1873. On diatoms from the Arctic Sea: Bihang. Svensk. Vetensk. Akad. Handl., v. 13, p. 1.

Cleve, P.T. and Grunow, A., 1880. Beiträge zur Kenntnis der arktischen Diatomeen: Kgl. Svensk. Vetensk. Akad. Handl., v. 17, p. 3-122.

Code of Stratigraphic Nomenclature, 1961: Am. Assoc. Petrol. Geol. Bull., v. 45, p. 5.

Conolly, J. and Ewing, M., 1965. Ice-rafted detritus as a climatic indicator in Antarctic deep-sea cores: Science, v. 150 , p. 1822 .

Donahue, J.G., 1970a. Diatoms as Quaternary biostratigraphic and paleoclimatic indicators in high latitudes of the Pacific Ocean: Ph.D. Thesis, Faculty of Pure Science, Columbia University.

1970b. Pleistocene diatoms as climatic indicators in North Pacific sediments: Geol. Soc. Am. Mem. 126, p. 121.

Ehrenberg, C.G., 1830 (1832). Beitrăge zur Kenntnis der Organisation der Infusorien und ihrer geographischen Verbreitung besonders in Sibirien: Abh. Kgl. Akad. Wiss. Berlin, p. 1-88.

- 1837. Die fossilen Infusorien und die lebendige Dammerde: Preuss. Physik. Abh. Kgl. Akad. Wiss. Berlin. 1838. Die Infusionstierchen als vollkommene Organismen. Ein Blick in das tiefere organische Leben der Natur: Leipzig (Leopold Voss), p. 1-7, 1-548.

1839 (1841). Uber noch jetzt zahlreich lebende Tierarten der Kreidebildung und den Organismus der Polythalamien: Abh. Kgl. Akad. Wiss. Berlin, p. 81-174. 1841. Uber Verbreitung und Einfluss des mikroskopischen Lebens in Süd- und Nordamerika. Ber. über die zur Bekanntmachung geeigneten Verhdlg. der Königl. preuss. Akad. Wiss. Berlin, p. 139-144.

1844. Resultate Untersuchungen der ihm von der Sudpolreise des Kapt. Rofs in den Jahren 1841-1843: Ber. Berl. Akad. Wiss., p. 182-207.

1844 (1845). Uber zwei neue Lager von Gebirgsmassen aus Infusorien als Meeresabsatz in NordAmerika und ein Vergleich derselben mit den organischen Kreidegebilden in Europa und Afrika: Abh. Kgl. Akad. Wiss. Berlin, p. 57-97.

1845. Vorläufige zweite Mitteilung uber die Beziehungen des kleinsten organischen Lebens zu den vulkanischen Massen der Erde: Ber. Akad. Wiss. Berlin, p. 133-157.

Forti, A., 1909. Studi per una monografia del genera Pyxilla (Diatomee) e dei generi affini: Nuova Notarisia, t. 24, p. 19-34.

Foster, J.H. and Opdyke, N.D., 1970. Upper Miocene to Recent magnetic stratigraphy in deep-sea sediments: J. Geophys. Res., v. 75 , p. $4465-4473$.

Frenguelli, J., 1949. Diatomeas fósiles de los yacimientos chilenos de Tiltil y Mejillones: Darwinia, v. 2, p. 97.
Goddell, H.G. and Watkins, N.D., 1968. The paleomagnetic stratigraphy of the Southern Ocean: $20^{\circ}$ west to $160^{\circ}$ east longitude: Deep-Sea Res. v. 15, p. 89-112.

Gordon, A.L., 1971a. Spreading of Antarctic bottom waters II. In Gordon, A.L. (Ed.), Studies in physical oceanography. A tribute to Georg Wust on his 80th birthday: New York (Gordon and Breach).

1971b. Recent physical oceanographic studies of Antarctic waters: Res. Antarctic, AAAS, p. 609-629.

Gran, H.H., 1904. Die Diatomeen der Arktischen Meere. I. Die Diatomeen des Planktons in "Fauna Arctica," auf Grund der Erg. der deutschen Expedition in das Nordliche Eismeer im Jahre 1898: v. 4, p. 511.

Greville, R.K., 1859. Descriptions of diatomaceae observed in Californian guano: Quat. J. Micr. Sci., v. 7, p. 155-166. 1860. A monograph of the genus Asterolampra, including Asteromphalus and Spatangidium: Micr. Soc. London Trans., v. 8, p. 102-124. 1862. On the Asterolamprae of the Barbados deposit: Micr. Soc. London Trans., v. 10, p. 41-55. 1863. Descriptions of new and rare diatoms: Micr. Soc. London Trans., v. 3, p. 227-237. 1865. Description of new and rare diatoms: Micr. Soc. London Trans., v. 13, p. 1. 1866. Descriptions of new and rare diatoms: Micr. Soc. London Trans., v. 14 (ser. XVII), p. 1; (ser. XIX), p. 77; (ser. XX), p. 121.

1868. Algae. In Reise der österreichischen Fregatte Novara um die Erde in den Jahren 1857, 1858, 1859: Bot. pt. 1 .

1884. Die Diatomeen von Franz-Josefs-Land: Denkschr. Math. Naturw. Klasse Kaiser. Akad. Wiss., v. 48 , p. $53-112$.

Grunow, A., 1862. Die österreichischen Diatomaceen nebst Anschluss einiger neuen Arten von anderen Lokalităten und einer kritischen Ubersicht der bisher bekannten Gattungen und Arten. Erste Folge: Epithemieae, Meridioneae, Diatomeae, Entopyleae, Surirelleae, Amphipleureae. Zweite Folge: Familie Nitzschieae: Verh. Kaiser.-Königl. Zool.-Bot. Ges. in Wien, v. 12, p. 315-472, 545-585. 1868. Algae in Reise Seiner Majestät Fregatte "Novara" um die Erde in den Jahren 1857, 1858, 1859: Botanischer Teil, v, 1, p. 1-104.

1881. In Van Heurck, H., Synopsis des diatomées de Belgique: Atlas., Taf. 124.

1884. Die Diatomeen von Franz-Josephs Land. Denkschrift: Math. Naturw. Klasse Kaiser. Akad. Wiss., v. 48 , p. 53-112.

Hanna, G.D., 1927. The lowest known Tertiary diatoms in California: J. Paleontol., v. 1, p. 103-126.

, 1930. A review of the genus Rouxia: J. Paleontol., v. 2, p. $179-188$.

, 1932. The diatoms of Sharktooth Hill, Kern County, California: Calif. Acad. Sci. Proc. (4th ser.), v. 20, p. 161-263.

Hanna, G.D. and Grant, W.M., 1926. Expedition to the Revillagigedo Islands, Mexico, in 1925; II Miocene marine diatoms from Maria Madre Island, Mexico: Calif. Acad. Sci. Proc. (4th ser.), v. 15, p. 115-193.

Hargraves, P., 1968. Species composition and distribution of net Plankton diatoms in the Pacific sector of the Antarctic Ocean: Ph.D. Thesis, Columbia University.

Hart, T.J., 1934. On the phytoplankton of the southwest Atlantic and the Bellingshausen Sea, 1929-1931: Discovery Rept., v. 8, p. 1-268.

1942. Phytoplankton periodicity in Antarctic surface waters: Discovery Rept., v. 21, p. 263-348.

Hasle, G.R., 1964. Nitzschia and Fragilariopsis species studied in the light and electron microscopes. I Some marine species of the groups Nitzschiella and Lanceolatae: Skr. Norske Vidensk.-Akad. I. Mat.-Nat. Kl., v. 16, p. 1-48. 
1965. Nitzschia and Fragilariopsis species studied in the light and electron microscopes. III The genus Fragilariopsis: Skr. Norske Vidensk.-Akad. I. Mat.-Nat. Kl., v. 21 , p. 1-49.

1969. An analysis of the phytoplankton of the Pacific Southern Ocean: Abundance, composition, and distribution during the Brategg Expedition 1947-1948: Hvalradets Skr. Sci. R. Marine Biol. Res., v. 52, p. 6-168. 1972. Fragilariopsis Hustedt as a section of the genus Nitzschia Hassal: Nova Hedw., Beihft., v. 39, p. 111-119.

Hasle, R.G. and Mendiola, B.R.E. de, 1967. The fine structure of some Thalassionema and Thalassiothrix species: Phycologia, v. 6, p. 107.

Hassal, A.H., 1845. A history of the British freshwater algae (including descriptions of Diatomaceae and Desmidiaceae) with upwards of one hundred plates: London (Taylor, Walton and Maberly).

Hays, J.D. and Berggren, W.A., 1971. Quaternary boundaries and correlations. In Funnell, B.M. and Riedel, W.R. (Eds.), Micropaleontology of the oceans: Cambridge (Cambridge University Press), p. 669-691.

Heiberg, P.A.C., 1863. Conspectus criticus diatomacearum Danicarum: Kjobenhavn (Wilhelm Priors Ferlag).

Heiden, H. and Kolbe, R.W., 1928. Die marinen Diatomeen der deutschen Südpolar-Expedition, 1901-1903. In Drygalski, E. (Ed.), Deutsche Sudpolar-Expedition 19011903: Berlin und Leipzig (Walter de Gruyter \& Co.), v. 8 (Botanik), no. 5, p. 447-715.

Hendey, N.J., 1937. The plankton diatoms of the southern seas: Discovery Rept., v. 16, p. 151-364. 1964. An introductory account of the smaller algae of British coastal waters. Part V: Bacillariophyceae (Diatoms): London (Her Majesty's Stationery Office).

Hendey, N.J. and Wiseman, D.H., 1953. The significance and diatom content of a deep-sea floor sample from the neighbourhood of the greatest oceanic depth: Deep-Sea Res., London (Pergamon Press), v. 1, p. 42-59.

Hustedt, F., 1924. Vom Sammeln und Präparieren der Kieselalgen sowie Angaben über Untersuchungs- und Kulturmethoden: Sonderdruck aus Handbuch der Biologischen Arbeitsmethoden, Abt. XI, Teil 4.

, 1928-1929. Die Kieselalgen Deutschlands, Osterreichs und der Schweiz. In L. Rabenhorst, Kryptogamen-Flora von Deutschland, Osterreich und der Schweiz; v. 7, p. 1-608.

1930. Die Kieselalgen Deutschlands, Osterreichs und der Schweiz. Kryptogamen-Flora von Deutsch., Osterr. Schweiz: v. 7, pt. 1, p. 609.

1931. Bacillariophyta (Diatomeae). A. Pascher, Die Süsswasser-Flora Mitteleuropas, 10 1. 2. Auflg. Jena (Fischer).

1952. Diatomeen aus der Lebensgemeinschaft des Buckelwals (Megaptera nodosa Bonn.): Archiv Hydrobiol.. v. 46 , p. 286-298.

1958. Diatomeen aus der Antarktis und dem Südatlantik: Deutsche Antarkt. Exped. 1938/1939, Hamburg, v. 2.

1959. Die Kieselalgen Deutschlands, Osterreichs und der Schweiz unter Berücksichtigung der ubrigen Länder Europas sowie der angrenzenden Meeresgebiete: Kryptogamen-Flora von Deutsch., Osterr. Schweiz, v. 7, p. 1.

, 1962. Die Kieselalgen Deutschlands, Osterreichs und der Schweiz unter Berücksichtigung der ubrigen Länder Europas sowie der angrenzenden Meeresgebiete. Kryptogamen-Flora von Deutsch., Osterr. Schweiz, v. 7, p. 1 . v. 3 , p. 349 .
Janisch, A.S., 1878. In Schmidt, A., Atlas der Diatomaceenkunde, Taf. 57.

Jörgensen, E., 1905. The protist plankton and the diatoms in bottom samples. In Nordgaard, O., Hydrographical and biological investigations in Norwegian Fjords: Bergen (Bergens Museum Skrift).

Jousé A.P., 1961. Stratigraphy of bottom sediments in the northwestern Pacific Ocean: Inst. Geol. Akad. Nauk SSSR Trans., v. 8, p. 183-196.

1962. Stratigraphic and paleogeographic studies in the northwestern part of the Pacific Ocean: Izd. Akad. Nauk. SSSR, Moscow, p. 1-258.

1971. Diatoms in Pleistocene sediments from the Northern Pacific Ocean. In Funnell, B.M. and Riedel, W.R. (Eds.), Micropaleontology of the oceans: Cambridge (Cambridge University Press), p. 407.

, 1974. Diatoms in the Oligocene-Miocene biostratigraphic zones of the tropical areas of the Pacific Ocean: Nova Hedw. Beihft., v. 45, p. 333.

Jousé, A.P., Koreleva, G.S., and Nagaieva, G.A., 1963. Stratigraphic and paleogeographic investigations in the Indian sector of the Southern Ocean: Oceanological Res., Articles, Section X, no. 8, Akad. Sci. SSSR, Moscow, p. $137-160$.

Jousé, A.P., Kozlova, O.G., and Muhina, V.V., 1971. Distribution of diatoms in the surface layer of sediment from the Pacific Ocean. In Riedel, W.R. and Funnell, B.M. (Eds.), Micropaleontology of the oceans; Cambridge (Cambridge University Press), p. 263-269.

Karsten, G., 1905. Das Phytoplankton des Antarktischen Meeres. In Chun, C. (Ed.), Wissenschaftliche Ergebnisse der Deutschen Tiefsee-Expedition auf dem Dampfer Valdivia, 1898-1899: Jena, p. 1-136.

, 1907. Das indische Phytoplankton. In Chun, C. (Ed.), Wissenschaftliche Ergebnisse der Deutschen Tiefsee-Expedition auf dem Dampfer 'Valdivia', 18981899: Jena, p. 223-544.

1928. Abteilung Bacillariophyta (Diatomeae). In Engler, A. and Prantl, K. (Eds.), Die natürlichen Pflanzenfamilien: Leipzig (Wilhelm Engelmann), v. 2, p. 105.

Kanaya, T., 1957. Eocene diatom assemblages from the Kellogg and "Sidney" Shales, Mt. Diablo Area, California: Sci. Rept. Tohoku Univ., 2nd Ser., v. 28, p. 1-124.

1959. Miocene diatom assemblages from the Onagawa Formation and their distribution in the correlative formations in Northeast Japan: Sci. Rept. Tohoku Univ., 2nd Ser., v. 30, p. 1.

1971. Some aspects of pre-Quaternary diatoms in the ocean. In Funnell, B.M. and Riedel, W.R. (Eds.), Micropaleontology of the oceans: Cambridge (Cambridge University Press), p. 545.

Koizumi, J., 1968. Tertiary diatom flora of Oga Peninsula, Akita Prefecture, northeast Japan: Sci. Rept. Tohoku Univ., 2nd ser. (Geol.), v. 40, p. 171-225.

1973. The late Cenozoic diatoms of Sites 183-193, Leg 19, Deep Sea Drilling Project. In Creager, J.S., Scholl, D.W., et al., Initial Reports of the Deep Sea Drilling Project, Volume 19: Washington (U.S. Government Printing Office), p. 805-856.

Kolbe, R.W., 1954. Diatoms from equatorial Pacific cores: Rept. Swedish Deep-Sea Exped., v. 6, p. 1-49.

Kozlova, O.G., 1964. Diatoms of the Indian and Pacific sectors of the Antarctic, English translation by: U.S. Dept. Comm. Clearinghouse Fed. Sci. Tech. Inform., Springfield, TT 66-51/54.

Kützing, F.T., 1833. Synopsis Diatomacearum oder Versuch einer systematischen Zusammenstellung der Diatomeen: Linnaea, v. 8, p. 529.

- 1844. Die kieselschaligen Bacillarien oder Diatomeen: S. Nordhausen. 
Lisitzin, A.P., 1960. Bottom sediments of the Eastern Antarctic and southern Indian Ocean: Deep-Sea Res., v. 7, p. 89.

McCollum, D.W., 1975. Leg 28 diatoms. In Hayes, D., Frakes, L.A., et al., Initial Reports of the Deep Sea Drilling Project, Volume 28: Washington (U.S. Government Printing Office), p. 515-572.

Mangin, L., 1915. Phytoplankton antarctique. Exp. Antarc. de la Scotia, 1902-1904: Mem. Acad. Sci. Paris, v. 57, p. 1-134.

Manguin, E., 1960. Les diatomées de la Terre Adelie: Ann. Sci. Naturelles, v. 1, p. 223-385.

Muhina, V.V., 1969. Biostratigraphy of sediments and some questions of paleogeography of the tropical region of the Pacific and Indian oceans: Micropaleontology and organogenous sedimentation in the oceans, p. 52-84.

O'Meara, E., 1877. On the diatomaceous gatherings made at Kerguelen's Land by H.N. Moseley, M.A., H.M.S. Challenger: J. Linn. Soc. (Bot.), v. 15, p. 55-59.

Opdyke, N.D., 1972. Paleomagnetism of deep-sea cores: Rev. Geophys. Space Physics, v. 10, p. 213-249.

Opdyke, N.D., Glass, B., Hays, J.D., and Foster, J., 1966. Paleomagnetic study of Antarctic deep-sea cores: Science, v. 154 , p. $349-357$.

Opdyke, N.D., Burckle, L.H., Hays, J.D., and Saito, T., 1970. Extension of the magnetic stratigraphy to the middle Miocene in deep-sea sediments (abstract): Geol. Soc. Am. Abstracts with Programs, v. 2, p. 642.

Opdyke, N.D., Burckle, L.H., and Todd, A., 1974. The extension of the magnetic time scale in sediments of the central Pacific Ocean: Earth Planet. Sci. Lett., v. 22, p. 300.

Peragallo, M., 1921. Diatomées d'eau salée. Deux. Exp. Antarct. France, 1908-1910: Sci. Natur., Docum. Sci., Bot., p. 1-98.

Proshkina-Lavrenko, A.J., 1955. Plankton diatoms of the Black Sea. Moscow-Leningrad.

Ralfs, J., 1861. In Pritchard, A history of infusoria, living and fossil: ed. IV, revised and enlarged, London.

Rattray, J., 1889. A revision of the Genus Coscinodiscus Ehr., and some allied genera: Proc. Roy. Soc. Edinburgh, v. 16, p. 449 (Reprint, Neill and Company, Edinburgh).

1890. A revision of the genus Actinocyclus Ehr: J. Quekett Micr. Club., v. 4, p. 137.

Riedel, W.R. and Sanfilippo, A., 1971. Cenozoic Radiolaria from the western tropical Pacific, Leg 7. In Winterer, E.L., Riedel, W.R. et al., Initial Reports of the Deep Sea Drilling Project, Volume 7: Washington (U.S. Government Printing Office), p. 1529-1672.

Saito, T., 1969. Late Cenozoic stage boundaries in deep-sea sediments (abstract). Geol. Soc. Am. Abstracts for 1969, p. $289-290$.

Sheshukova-Poretskaya, V.S., 1962. Novie i redkie Bacillariophyta iz diatomovoi sviti Sakhalina: Uchenie Zapiski Igu, Ser. Biol. Nauk (Leningrad Univ.), v. 49, p. 203.

Schmidt, A. et al., 1874. Atlas der Diatomaceenkunde. Heft 1-120, Taf. 1-460 (Taf. 1-216 A. Schmidt; 213-216 M. Schmidt; $217-240$ (1900-1901) F. Fricke; 241-244 (1903) H. Heiden; 245-246 (1904) O. Muller; 247-256 (1904-1905) F. Fricke; 257-264 (1905-1906) H. Heiden; 265-268 (1906) F. Fricke; 269-472 (1911-1959) F. Hustedt), (R. Reisland), Leipzig.
Schrader, H.-J., 1969. Die pennaten Diatomeen aus dem Obereozän von Oamaru, Neuseeland: Nova Hedw., Beihft., v. 28 , p. 1-124.

1973a. Cenozoic diatoms from the northeast Pacific, Leg 18. In Kulm. L. D., von Huene, R., et al., Initial Reports of the Deep Sea Drilling Project, Volume 18: Washington (U.S. Government Printing Office), p. 673797.

1973b. Stratigraphic distribution of marine Denticula species in Neogene North Pacific sediments, Micropaleontology, v. 19, p. 417-430.

1974a. Cenozoic marine planktonic diatom biostratigraphy of tropical Indian Ocean. In Fisher, R., Bunce, E., et al., Initial Reports of the Deep Sea Drilling Project, Volume 24: Washington (U.S. Government Printing Office), p. 887.

1974b. Proposal for a standardized method of cleaning diatom-bearing deep-sea and land-exposed marine sediments. Nova Hedw., Beihft, v. 45, p. 403-409. $1974 \mathrm{c}$. Revised diatom biostratigraphy of the Experimental Mohole Drilling, Guadalupe Site: Proc. Calif. Acad. Sci., v. 39 , p. 517-562.

Schrader, H.-J. and Burckle, L., in preparation. Marine diatom biostratigraphy, its correlation to other microfossil zonation and to the paleomagnetic record.

Simonsen, R., 1974. The diatom plankton of the Indian Ocean Expedition of R/V "Meteor" 1964-1965. "Meteor" Forschung. Reihe D, no. 19, p. 1-66.

Simonsen, R. and Kanaya, T., 1961. Notes on the marine species of the diatom genus Denticula Kutz: Internatl. Rev. Ges. Hydrobiol., v. 46, p. 498-513.

Smith, H.L., 1887. In Christian, T., 1887. New diatomaceous deposits: The microscope, v. 7, p. 65-68.

Stradner, H. and Papp, A., 1961. Tertiäre Descoasteriden aus Osterreich und deren stratigraphische Bedeutung: J. Geol. B.A., Sonderband 7, p. 1-160.

Tempère, J. and Peragallo, H., 1910. Diatomees du Monde Entier: ed. 2, Arcachon, Grez-sur-Loing (S.-et-M.), Pt. 1, p. 209.

Theyer, F. and Hammond, S.R., 1974. Paleomagnetic polarity sequence and radiolarian zones, Brunhes to polarity epoch 20: Earth Planet, Sci. Lett., v. 22, p. 307.

Van Heurck, H., 1909. Diatomées: Resultats du voyage du S.Y. "Belgica" en 1897-1899: Rapports Sci., Bot., p. 3126.

Van Landingham, S.L., 1967-1971. Catalogue of the fossil and Recent genera and species of diatoms and their synonyms: Part I (1967) Acanthoceras through Cacillaria, Part II (1968) Bacteriastrum through Coscinodiscus, Part III (1969) Coscinosphaena through Fibula, Part IV (1971) Fragilaria through Naunema (Cramer) Lehre.

Wallich, G.C., 1860. On the siliceous organisms found in the digestive cavities of the Salpae, and their relation to the Flint nodules of the Chalk Formation: Micr. Soc. London Trans., v. 8 , p. 36.

Zabelina, M.M., 1934. Diatoms from the Tertiary deposits of the eastern coast of Kamchatka: Oil Geol. Inst. Trans., v. 48 , p. $3-19$. 



\section{PLATE 1}

(Magnification $1500 \times$, except Figures $1=55 \times$ and $7=700 \times$ )

Figure $1 \quad$ Synedra miocenica sp. nov.; Sample 278-18-1, 50 $\mathrm{cm}$ (Type).

Figure 2 Thalassiothrix primitiva sp. nov.; Sample 278-32-6, $50 \mathrm{~cm}$ (Type).

Figure 3 Thalassiothrix primitiva sp. nov; Sample 278-33-1, $50 \mathrm{~cm}$.

Figure 4 Thalassiothrix primitiva sp. nov.; Sample 278-21-1, $50 \mathrm{~cm}$.

Figure 5 Thalassiothrix longissima Cleve and Grunow; Sample 278-9-1, $50 \mathrm{~cm}$.

Figure 6 Thalassiothrix longissima; Sample 278-13-1, $50 \mathrm{~cm}$.

Figure 7 Thalassiothrix frauenfeldii (Grun.) Grunow; Sample $278-14-1,50 \mathrm{~cm}$.

Figure $8 \quad$ Thalassiothrix frauenfeldii; Sample 278-14-1, 50 $\mathrm{cm}$.

Figure $9 \quad$ Thalassiothrix frauenfeldii; Sample 278-14-1, 50 $\mathrm{cm}$.

Figure $10 \quad$ Thalassiothrix frauenfeldii; Sample 278-14-1, 50 $\mathrm{cm}$.

Figure $11 \quad$ Synedra jouseana Shes.-Poretzkaya; Sample 278$33-6,50 \mathrm{~cm}$.

Figure 12 Synedra jouseana; Sample 278-23-1, $80 \mathrm{~cm}$.

Figure 13 Synedra jouseana; Sample 278-27-1, $50 \mathrm{~cm}$.

Figure 14 Thalassionema hirosakiensis (Kan.) Schrader; Sample 278-33-6, $50 \mathrm{~cm}$.

Figure 15 Thalassionema hirosakiensis; Sample 278-33-1, 50 $\mathrm{cm}$.

Figure 16 Thalassionema hirosakiensis; Sample 278-29-4, 20 $\mathrm{cm}$.

Figure 17 Thalassiothrix longissima; Sample 278-11-1, $50 \mathrm{~cm}$. 
PLATE 1

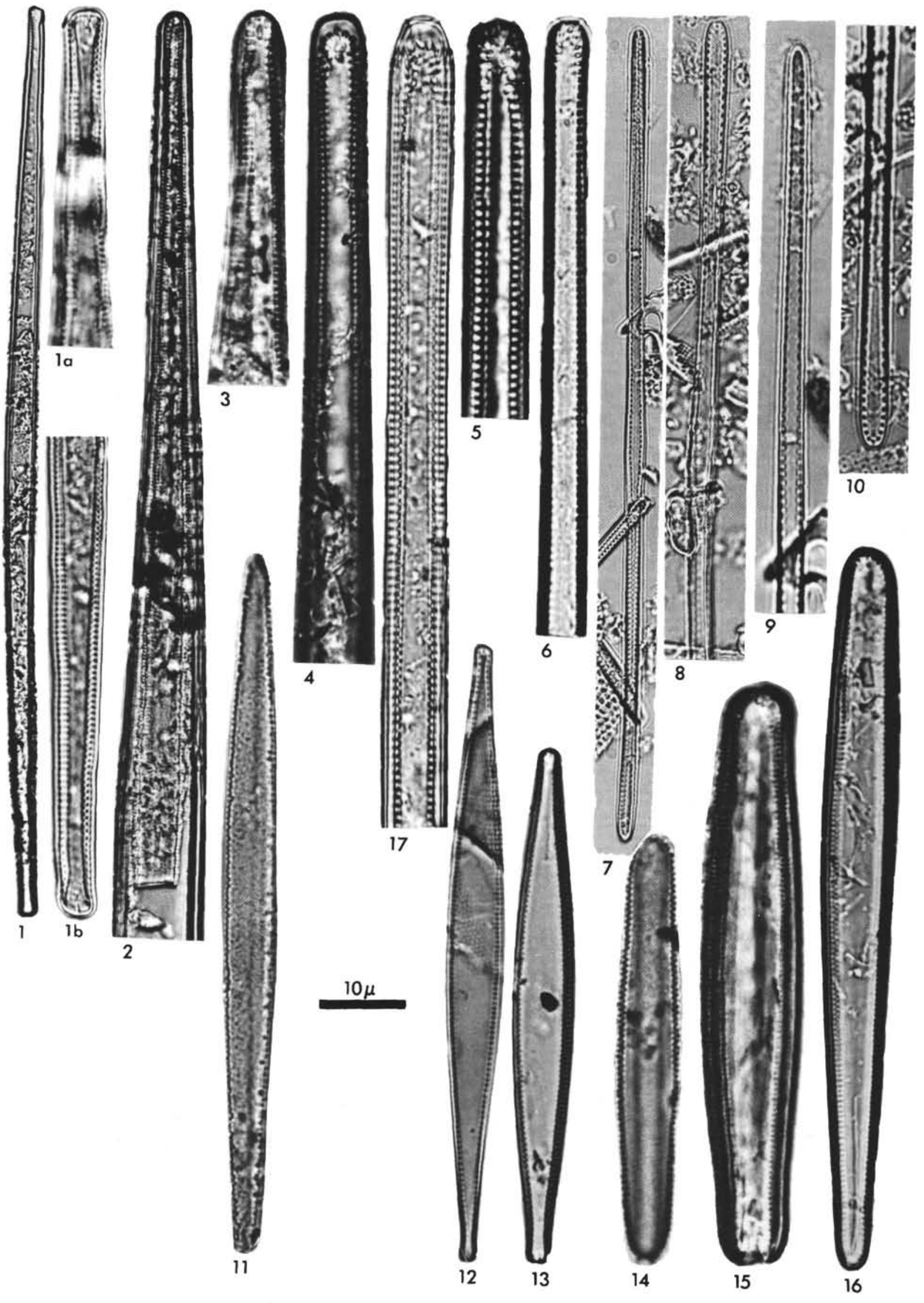


PLATE 2

(Magnification 1500×)

Figure 1

Figure 2

Figure 3

Figure 4

Figure 5

Figure 6

Figure 7

Figure 8

Figure 9

Figure 10

Figure 11

Figure 12

Figure 13

Figure 14

Figure 15

Figure 16

Figure 17

Figure 18

Figure 19

Figure 20

Figure 21

Figure 22

Figure 23

Figure 24

Figure 25

Figure 26

Figure 27

Figure 28

Figure 29

Figure 30

Figure 31

Figure 32

Figure 33

Figure 34

Figure 35

Figure 36

Figure 37
Nitzschia efferans sp. nov.; Sample 278-17-1, $50 \mathrm{~cm}$ (Type).

Nitzschia claviceps sp. nov.; Sample 278-11-1, $50 \mathrm{~cm}$ (Type).

Nitzschia efferans sp. nov.; Sample 278-11-1, $50 \mathrm{~cm}$.

Nitzschia claviceps sp. nov.; Sample 278-11-1, $50 \mathrm{~cm}$.

Nitzschia efferans sp. nov.; Sample 278-16-1, $50 \mathrm{~cm}$.

Nitzschia efferans sp. nov.; Sample 278-13-1, $50 \mathrm{~cm}$.

Nitzschia efferans sp. nov.; Sample 278-13-1, $50 \mathrm{~cm}$.

Nitzschia sp. 14; Sample 278-14-1, $50 \mathrm{~cm}$.

Nitzschia maleinterpretaria sp. nov.; Sample 278-24-1, $50 \mathrm{~cm}$ (Type).

Nitzschia sp. 17; Sample 278-18-1, $50 \mathrm{~cm}$.

Nitzschia maleinterpretaria sp. nov.; Sample 278-21-1, $50 \mathrm{~cm}$.

Nitzschia maleinterpretaria sp. nov.; Sample 278-27-1, $50 \mathrm{~cm}$.

Nitzschia maleinterpretaria sp. nov.; Sample 278-17-1, $50 \mathrm{~cm}$.

Nitzschia maleinterpretaria sp. nov.; Sample 278-17-1, $50 \mathrm{~cm}$.

Nitzschia maleinterpretaria sp. nov.; Sample 278-19-2, $50 \mathrm{~cm}$.

Nitzschia maleinterpretaria sp. nov.; Sample 278-27-1, $50 \mathrm{~cm}$.

Nitzschia maleinterpretaria sp. nov.; Sample 278-9-1, $50 \mathrm{~cm}$.

Nitzschia maleinterpretaria sp. nov.; Sample 278-27-1, $50 \mathrm{~cm}$.

Nitzschia maleinterpretaria sp. nov.; Sample 278-24-1, $50 \mathrm{~cm}$.

Nitzschia pusilla sp. nov.; Sample 278-21-1, $50 \mathrm{~cm}$ (Type).

Nitzschia maleinterpretaria sp. nov.; Sample 278-27-1, $50 \mathrm{~cm}$.

Nitzschia evenescens sp. nov.; Sample 278-17-1, $50 \mathrm{~cm}$ (Type).

Nitzschia evenescens sp. nov.; Sample 278-17-1, $50 \mathrm{~cm}$.

Nitzschia maleinterpretaria sp. nov.; Sample 278-24-1, $50 \mathrm{~cm}$.

Nitzschia januaria sp. nov.; Sample 278-9-1, $50 \mathrm{~cm}$.

Nitzschia januaria sp. nov.; Sample 278-11-1, $50 \mathrm{~cm}$ (Type).

Nitzschia januaria sp. nov.; Sample 278-9-1, $50 \mathrm{~cm}$.

Nitzschia januaria sp. nov.; Sample 278-9-1, $50 \mathrm{~cm}$.

Nitzschia januaria sp. nov.; Sample 278-9-1, $50 \mathrm{~cm}$.

Nitzschia donahuensis sp. nov.; Sample 278-14-1, $50 \mathrm{~cm}$ (Type).

Nitzschia sicula var. rostrata Hustedt; Sample 278-10-1, $50 \mathrm{~cm}$.

Nitzschia aff. porteri Frenguelli; Sample 278-11-1, $50 \mathrm{~cm}$.

Nitzschia porteri Frenguelli; Sample 278-11-1, $50 \mathrm{~cm}$.

Nitzschia porteri; Sample 278-14-1, $50 \mathrm{~cm}$.

Nitzschia porteri; Sample 278-11-1, $50 \mathrm{~cm}$.

Nitzschia sp. 14; Sample 278-11-1, $50 \mathrm{~cm}$.

Nitzschia sp. 16; Sample 278-9-1, $50 \mathrm{~cm}$. 
PLATE 2
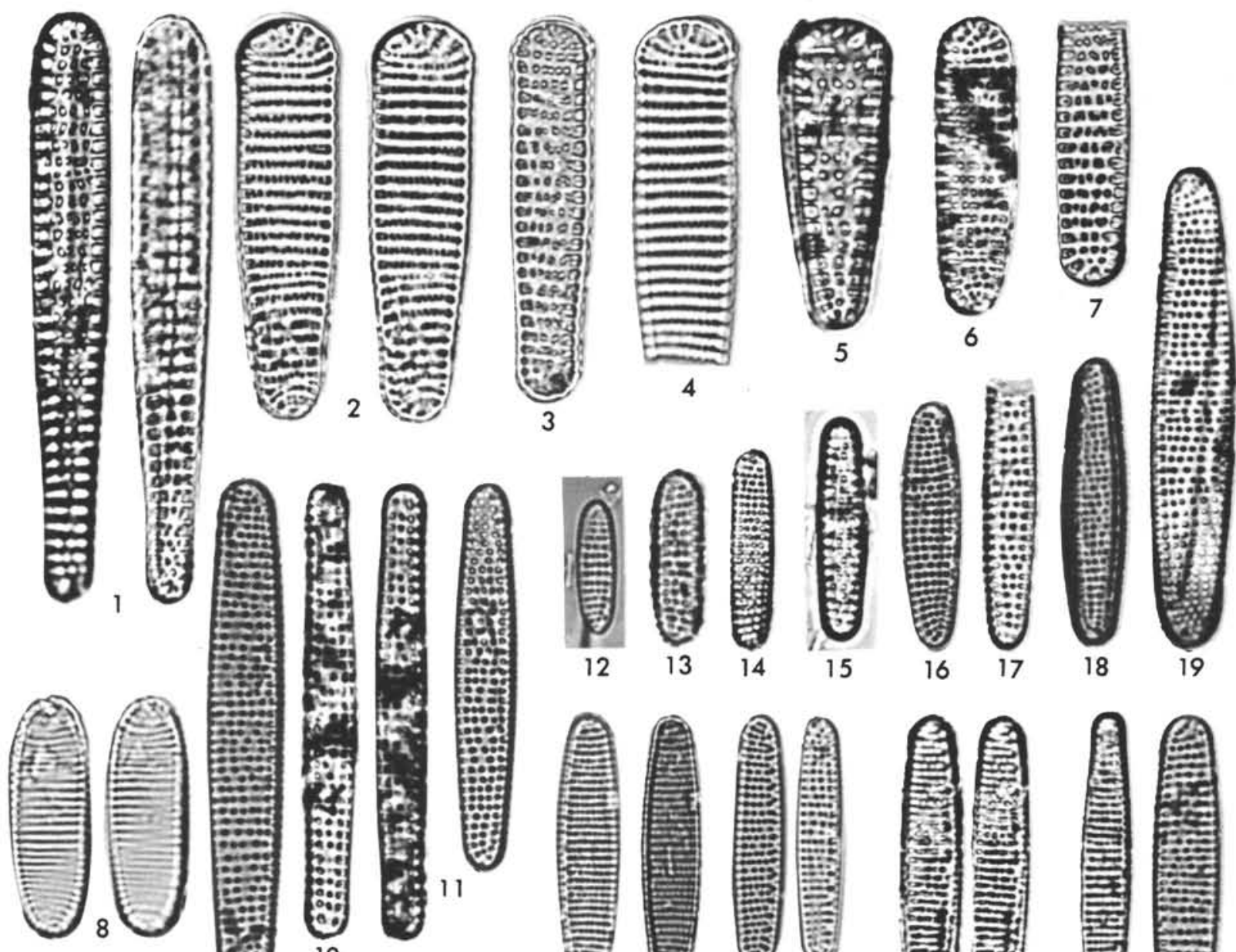

19
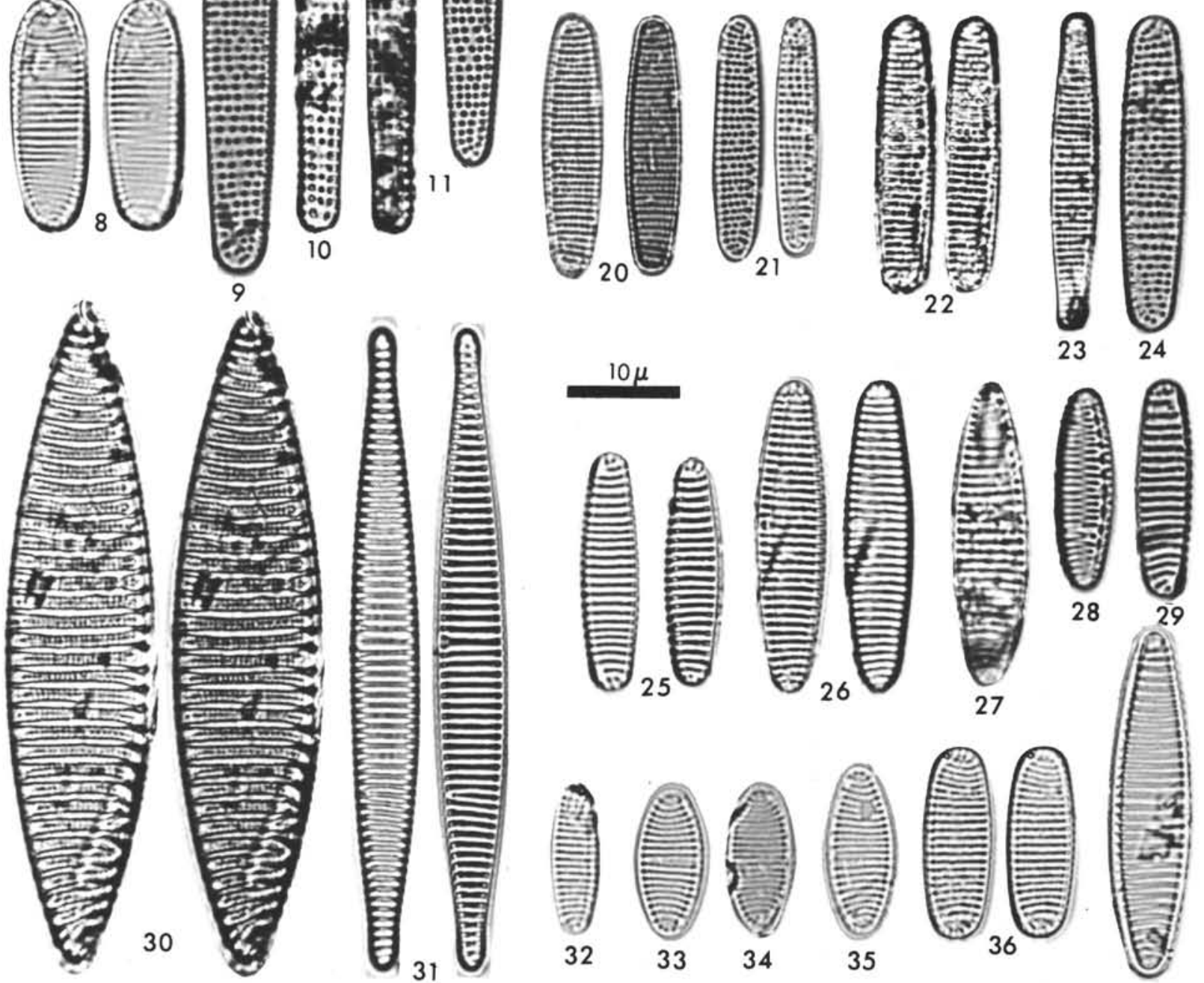
PLATE 3

(Magnification $1500 \times$ )

Figure $1 \quad$ Nitzschia grossepunctata sp. nov.; Sample 278-19$2,50 \mathrm{~cm}$.

Figure $2 \quad$ Nitzschia grossepunctata sp. nov.; Sample 278-19$2,50 \mathrm{~cm}$.

Figures 3, $4 \quad$ Nitzschia grossepunctata sp. nov.; Sample 278-202, $60 \mathrm{~cm}$ (Type).

Figures 5,6 Nitzschia interfrigidaria McCollum; Sample 278$11-1,50 \mathrm{~cm}$.

Figure $7 \quad$ Nitzschia denticuloides sp. nov.; Sample 278-15-2, $50 \mathrm{~cm}$.

Figure $8 \quad$ Nitzschia denticuloides sp. nov.; Sample 278-16-1, $50 \mathrm{~cm}$.

Figure 9 Denticula antarctica McCollum; Sample 278-17-1, $50 \mathrm{~cm}$.

Figure $10 \quad$ Nitzschia denticuloides sp. nov.; Sample 278-13-1, $50 \mathrm{~cm}$.

Figure 11 Denticula antarctica; Sample 278-9-1, $50 \mathrm{~cm}$.

Figure 12 Nitzschia denticuloides sp. nov.; Sample 278-14-1, $50 \mathrm{~cm}$.

Figures 13, 14 Nitzschia sp. 17; Sample 278-20-2, $60 \mathrm{~cm}$.

Figure $15 \quad$ Nitzschia sp. 17; Sample 278-20-2, $60 \mathrm{~cm}$.

Figure 16 Denticula aff. antarctica McCollum; Sample 278$17-1,50 \mathrm{~cm}$.

Figure $17 \quad$ Nitzschia sp. 17; Sample 278-17-1, $50 \mathrm{~cm}$.

Figure 18 Nitzschia denticuloides sp. nov.; Sample 278-14-1, $50 \mathrm{~cm}$.

Figure $19 \quad$ Nitzschia denticuloides sp. nov.; Sample 278-14-1, $50 \mathrm{~cm}$.

Figure $20 \quad$ Nitzschia denticuloides sp. nov.; Sample 278-14-1, $50 \mathrm{~cm}$.

Figures 21, 22 Nitzschia denticuloides sp. nov.; Sample 278-11-1, $50 \mathrm{~cm}$ (Type).

Figure $23 \quad$ Nitzschia denticuloides sp. nov.; Sample 278-14-1, $50 \mathrm{~cm}$.

Figure $24 \quad$ Nitzschia denticuloides sp. nov.; Sample 278-14-1, $50 \mathrm{~cm}$. 


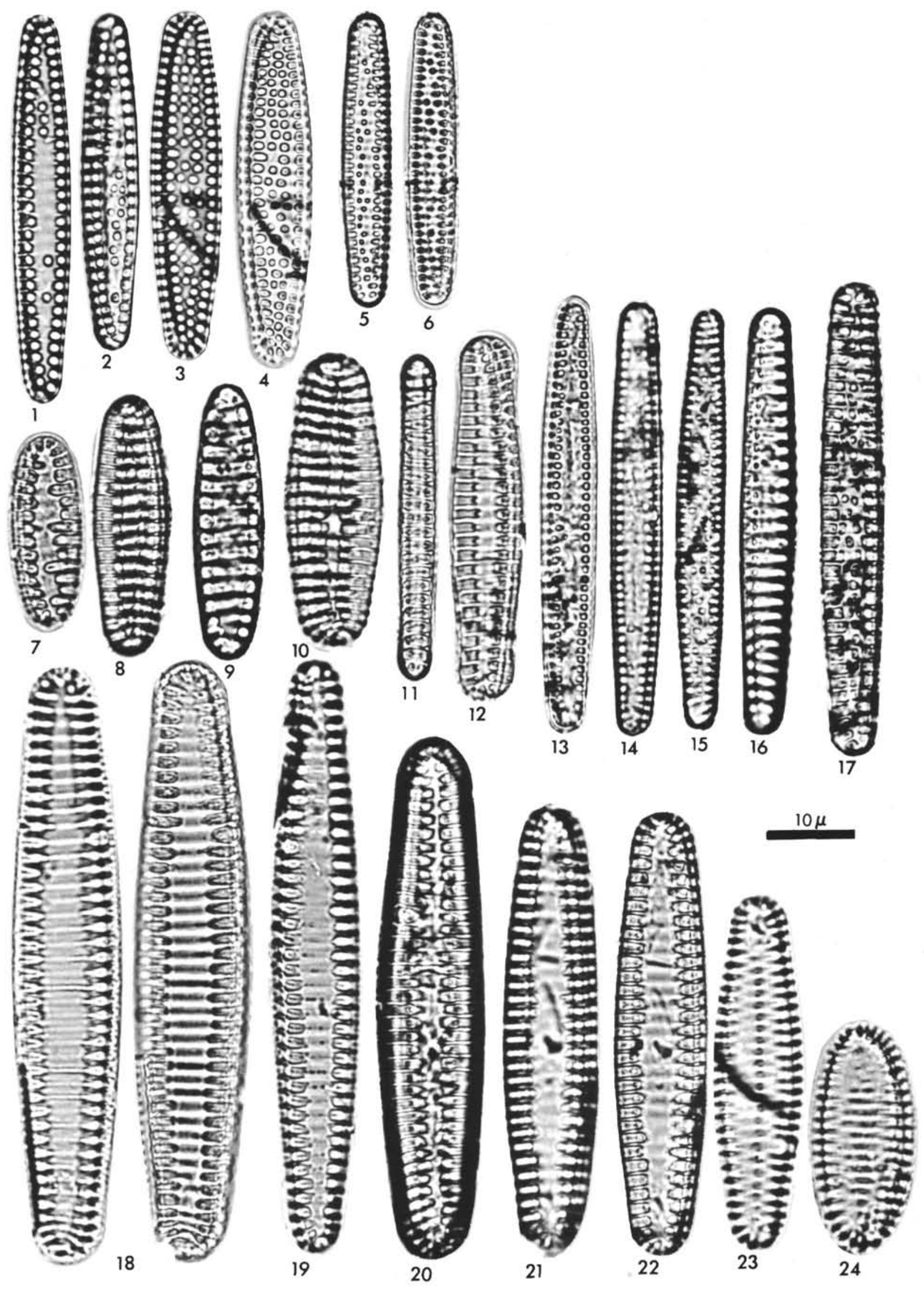


PLATE 4

(Magnification 1500X)

Figure 1

Figure 2

Figure 3

Figure 4

Figure 5

Figure 6

Figure 7

Figure 8

Figure 9

Figure 10

Figure 11

Figure 12

Figure 13

Figure 14

Figure 15

Figure 16

Figure 17

Figure 18

Figure 19

Figure 20

Figure 21

Figure 22

Figure 23

Figure 24

Figure 25

Figure 26

Figure 27

Figure 28

Figure 29

Figure 30

Figure 31

Figure 32
Denticula aff. antarctica McCollum; Sample 278-19-2, $50 \mathrm{~cm}$.

Denticula hustedtii Simonsen and Kanaya; Sample 278-14-1, $50 \mathrm{~cm}$.

Denticula antarctica McCollum; Sample 278-20-2, $60 \mathrm{~cm}$.

Denticula hustedtii; Sample 278-16-1, $50 \mathrm{~cm}$.

Denticula hustedtii var. ovata var. nov.; Sample 278-9-1, $50 \mathrm{~cm}$ (Type).

Denticula hustedtii var, ovata var. nov.; Sample 278-9-1, $50 \mathrm{~cm}$.

Denticula lauta var. ovata var. nov.; Sample 278-13-1, $50 \mathrm{~cm}$ (Type).

Denticula hustedtii; Sample 278-9-1, $50 \mathrm{~cm}$.

Denticula hustedtii; Sample 278-10-1, $50 \mathrm{~cm}$.

Denticula lauta Bailey; Sample 278-14-1, $50 \mathrm{~cm}$.

Denticula lauta; Sample 278-14-1, $50 \mathrm{~cm}$.

Denticula hustedtii var. ovata var. nov.; Sample 278-12-1, $50 \mathrm{~cm}$.

Denticula lauta; Sample 278-14-1, $50 \mathrm{~cm}$.

Denticula hustedtii var. ovata var. nov.; Sample 278-12-1, $50 \mathrm{~cm}$.

Denticula hustedtii var. ovata var. nov.; Sample 278-12-1, $50 \mathrm{~cm}$.

Denticula punctata Schrader; Sample 278-10-1, $50 \mathrm{~cm}$.

Denticula hyalina Schrader; Sample 278-23-1, $80 \mathrm{~cm}$.

Denticula aff. kamtschatica Zabelina; Sample 278-12-1, $50 \mathrm{~cm}$.

Denticula nicobarica Grunow; Sample 278-17-1, $50 \mathrm{~cm}$.

Denticula nicobarica; Sample 278-15-2, $50 \mathrm{~cm}$.

Denticula nicobarica; Sample 278-17-1, $50 \mathrm{~cm}$.

Denticula antarctica; Sample 278-17-1, $50 \mathrm{~cm}$.

Denticula antarctica; Sample 278-18-1, $50 \mathrm{~cm}$.

Denticula hyalina; Sample 278-20-2, $60 \mathrm{~cm}$.

Denticula antarctica; Sample 278-17-1, $50 \mathrm{~cm}$.

Denticula sp. 1; Sample 278-11-1, $50 \mathrm{~cm}$.

Denticula dimorpha Schrader; Sample 278-20-2, $60 \mathrm{~cm}$.

Denticula lauta; Sample 278-13-1, $50 \mathrm{~cm}$.

Denticula dimorpha; Sample 278-14-1, $50 \mathrm{~cm}$.

Denticula dimorpha; Sample 278-14-1, $50 \mathrm{~cm}$.

Denticula dimorpha; Sample 278-14-1, $50 \mathrm{~cm}$.

Denticula dimorpha; Sample 278-14-1, $50 \mathrm{~cm}$. 
PLATE 4

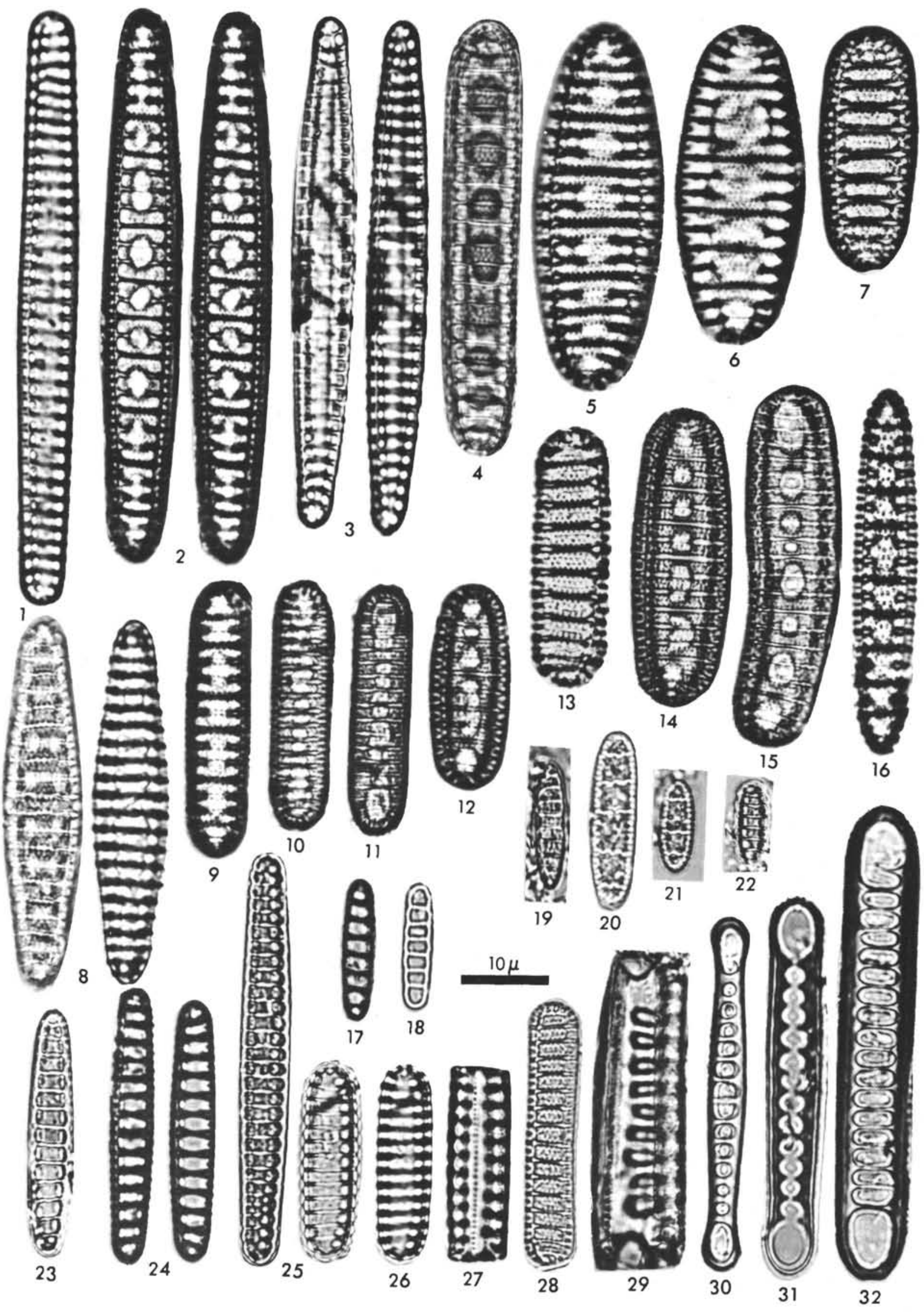


PLATE 5

(Magnification $1500 \times$ )

Figures 1, 2 Rouxia antarctica Heiden and Kolbe; Sample 278$14-1,50 \mathrm{~cm}$.

Figure 3 Rouxia antarctica; Sample 278-14-1, $50 \mathrm{~cm}$.

Figure 4 Rouxia antarctica; Sample 278-14-1, $50 \mathrm{~cm}$.

Figure 5 Rouxia antarctica; Sample 278-14-1, $50 \mathrm{~cm}$.

Figure 6 Rouxia antarctica; Sample 278-14-1, $50 \mathrm{~cm}$.

Figure 7 Rouxia antarctica; Sample 278-14-1, $50 \mathrm{~cm}$.

Figure $8 \quad$ Rouxia antarctica; Sample 278-14-1, $50 \mathrm{~cm}$.

Figure 9 Rouxia isopolica sp. nov.; Sample 278-11-1, $50 \mathrm{~cm}$.

Figure $10 \quad$ Navicula sp. 1; Sample 278-24-1, $50 \mathrm{~cm}$.

Figure $11 \quad$ Rouxia sp. 2; Sample 278-11-1, $50 \mathrm{~cm}$.

Figure 12 Rouxia sp. 2; Sample 278-11-1, $50 \mathrm{~cm}$.

Figure 13 Rouxia naviculoides Schrader; Sample 278-9-1, 50 $\mathrm{cm}$.

Figure $14 \quad$ Rouxia isopolica sp. nov.; Sample 278-18-1, $50 \mathrm{~cm}$.

Figure $15 \quad$ Rouxia isopolica sp. nov.; Sample 278-11-1, $50 \mathrm{~cm}$ (Type).

Figure 16 Genus et species indet.; Sample 278-30-2, $50 \mathrm{~cm}$.

Figure 17 Cestodiscus sp. 1; Sample 278-24-1, $50 \mathrm{~cm}$.

Figure $18 \quad$ Rouxia naviculoides; Sample 278-14-1, $50 \mathrm{~cm}$.

Figure 19 Raphidodiscus marylandicus Christian; Sample 278-27-1, $50 \mathrm{~cm}$.

Figure $20 \quad$ Rouxia isopolica sp. nov.; Sample 278-11-1, $50 \mathrm{~cm}$.

Figure $21 \quad$ Rouxia californica Peragallo; Sample 278-9-1, 50 $\mathrm{cm}$.

Figure 22 Bogorovia veniamini Jousé; Sample 278-30-2, 50 $\mathrm{cm}$.

Figure 23 Bogorovia veniamini; Sample 278-30-2, $50 \mathrm{~cm}$. 
PLATE 5

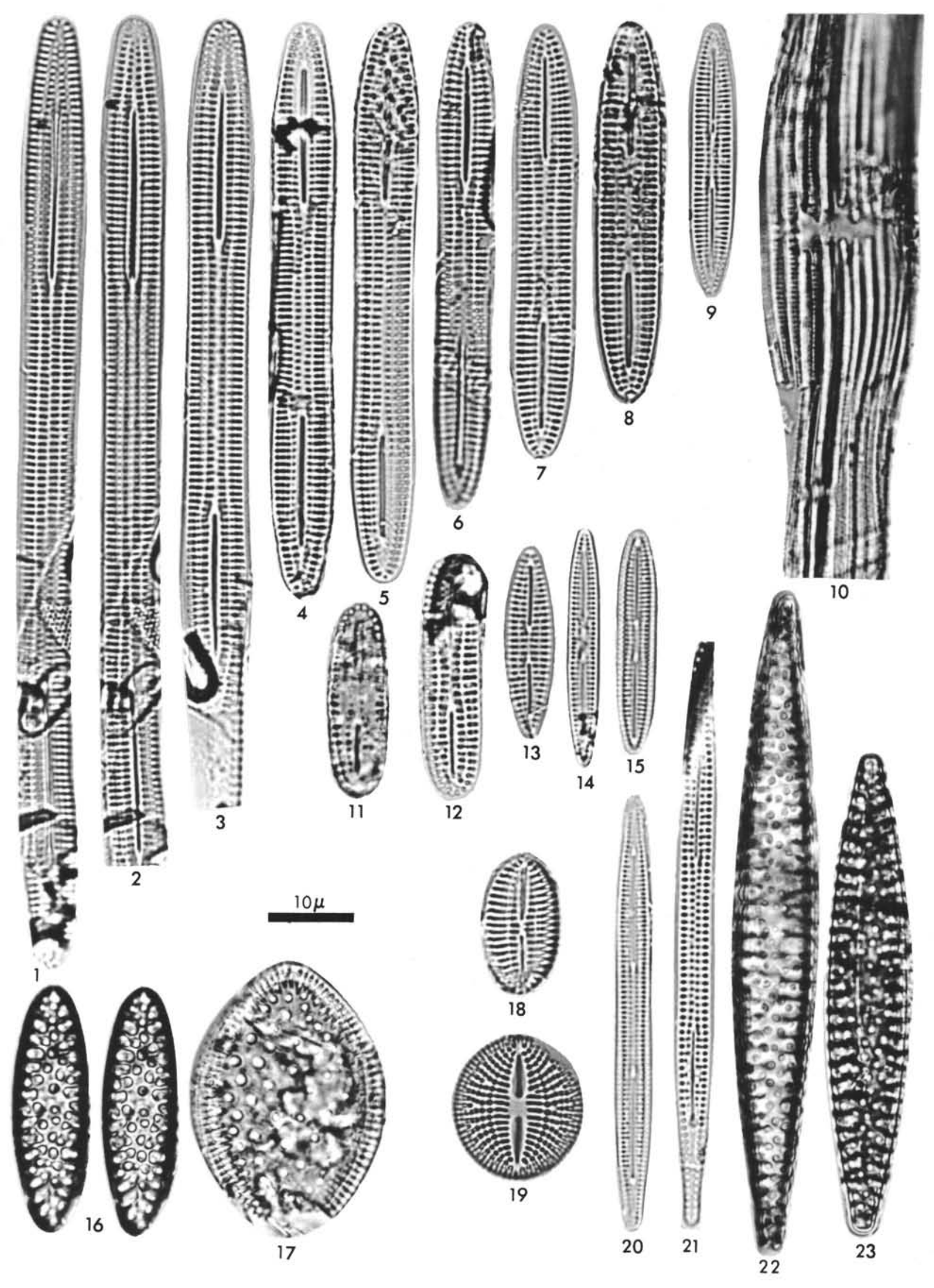


PLATE 6

(Magnification $1500 \times$ )

Figures 1, 2 Thalassiosira spumellaroides sp. nov.; Sample 278$25-1,100 \mathrm{~cm}$ (Type).

Figure 3 Thalassiosira spinosa var. aspinosa var. nov.; Sample 278-27-1, $50 \mathrm{~cm}$ (Type).

Figure 4 Coscinodiscus ruboides sp. nov.; Sample 278-21-1, $50 \mathrm{~cm}$ (Type).

Figure $5 \quad$ Thalassiosira spinosa sp. nov.; Sample 278-27-1, 50 $\mathrm{cm}$.

Figure 6 Thalassiosira spinosa sp. nov.; Sample 278-27-1, 50 cm (Type).

Figure 7 Thalassiosira spinosa sp. nov.; Sample 278-27-1, 50 $\mathrm{cm}$.

Figure 8 Coscinodiscus ruboides sp. nov.; Sample 278-30-2, $50 \mathrm{~cm}$.

Figure 9 Coscinodiscus sp. 4; Sample 278-23-1, $80 \mathrm{~cm}$. 
PLATE 6
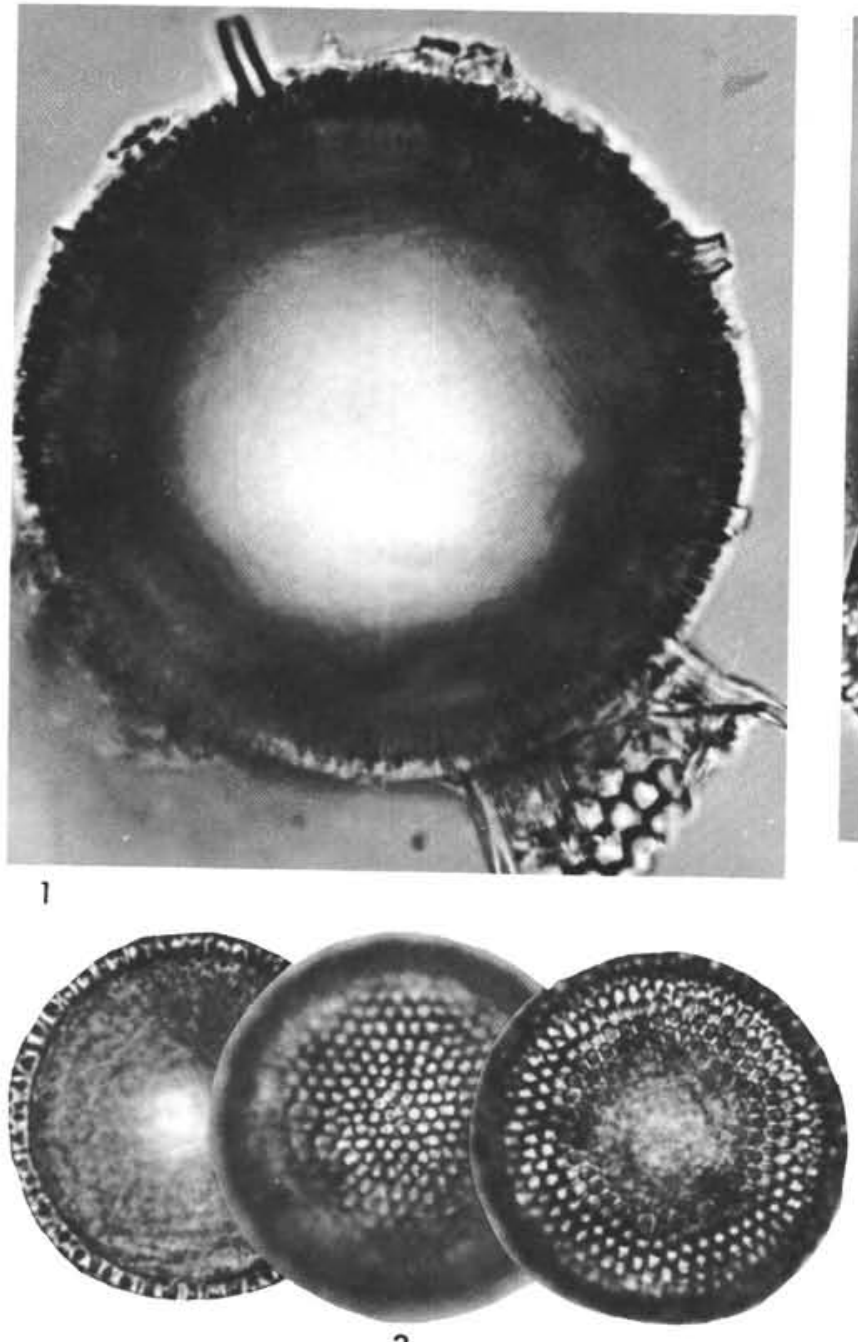

3
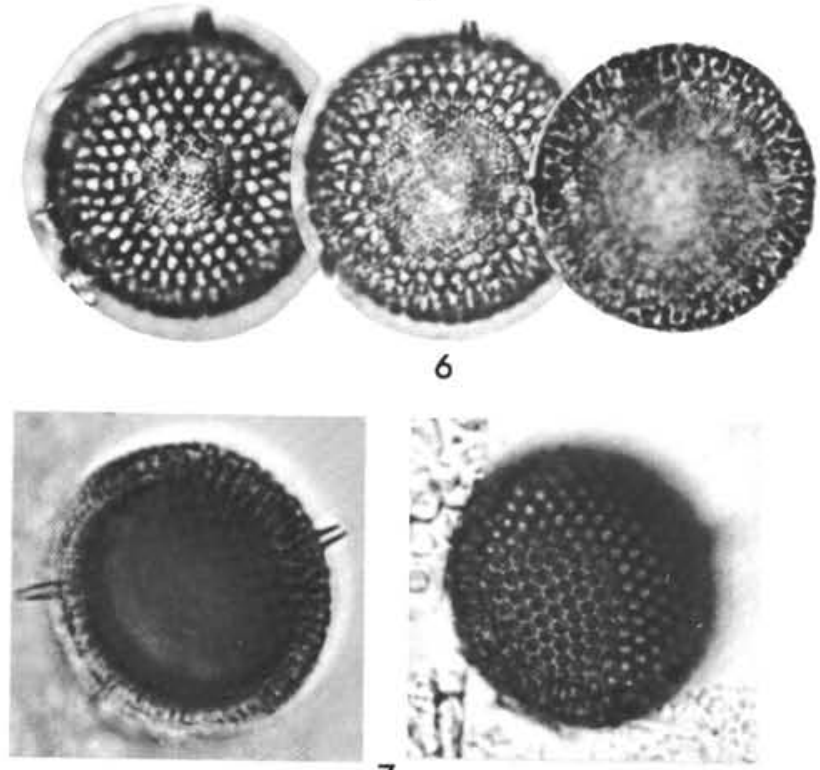

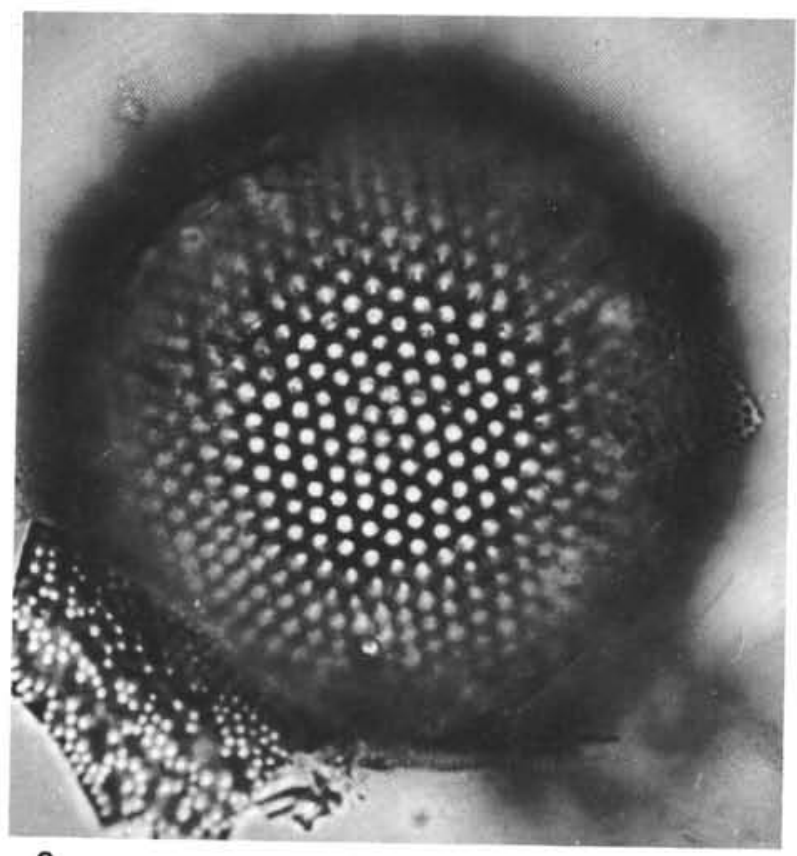

2
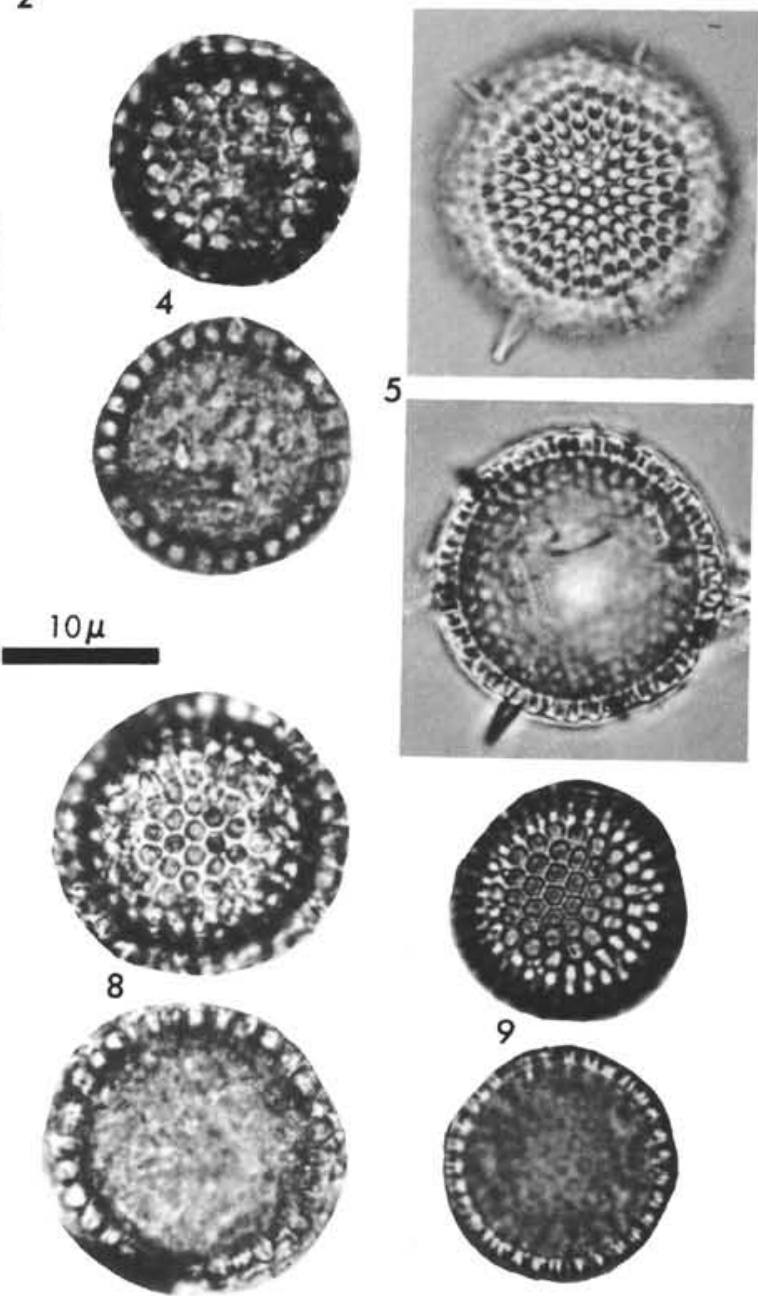

5
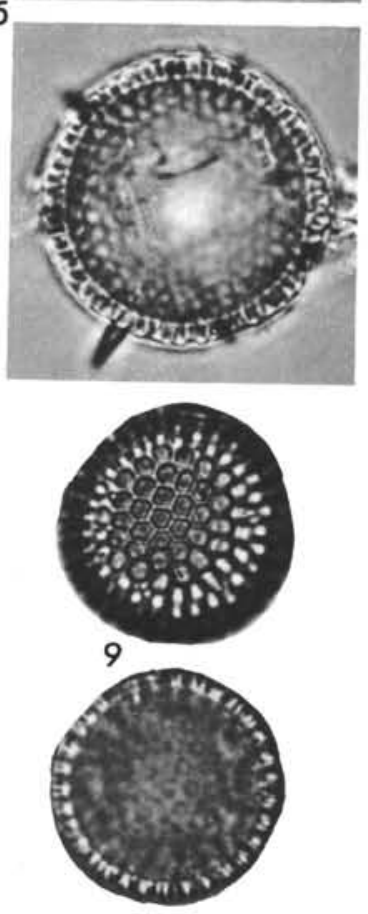


\section{PLATE 7}

(Magnification $1500 \times$ )

Figure 1a Coscinodiscus symbolophorus group 1; Sample 278$33-1,50 \mathrm{~cm}$.

Figure 1 Coscinodiscus symbolophorus group 1; Sample 278$32-4,120 \mathrm{~cm}$.

Figure 2 Coscinodiscus symbolophorus group 2; Sample 278$13-1,50 \mathrm{~cm}$.

Figure 3 Coscinodiscus symbolophorus group 3; Sample 27829-3, $50 \mathrm{~cm}$. 
PLATE 7
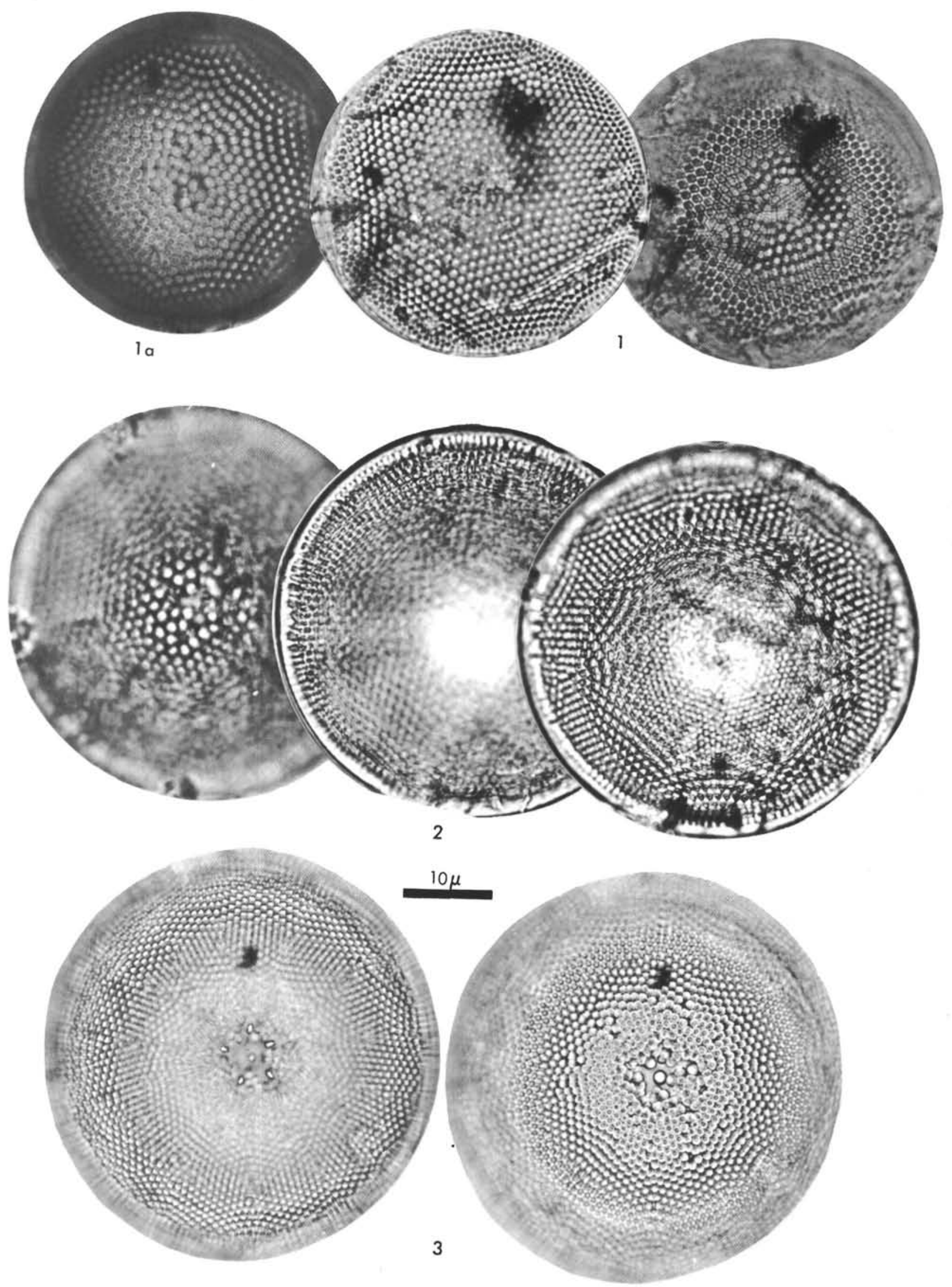
PLATE 8

(Magnification $1500 \times$ )

Figure $1 \quad$ Asteromphalus sp. 2; Sample 278-21-1, $50 \mathrm{~cm}$.

Figure 2 Asterolampra sp. 2; Sample 278-32-4, $50 \mathrm{~cm}$.

Figure 3 Asteromphalus parvulus Karsten; Sample 278-29-4, $20 \mathrm{~cm}$.

Figure $4 \quad$ Asteromphalus sp. 3; Sample 278-28-2, $50 \mathrm{~cm}$.

Figure $5 \quad$ Asteromphalus aff. hyalinus; Sample 278-9-1, 50 $\mathrm{cm}$.

Figure 6 Asteromphalus parvulus; Sample 278-27-1, $50 \mathrm{~cm}$.

Figure 7 Asteromphalus hyalinus Karsten; Sample 278-23-1, $80 \mathrm{~cm}$. 
PLATE 8
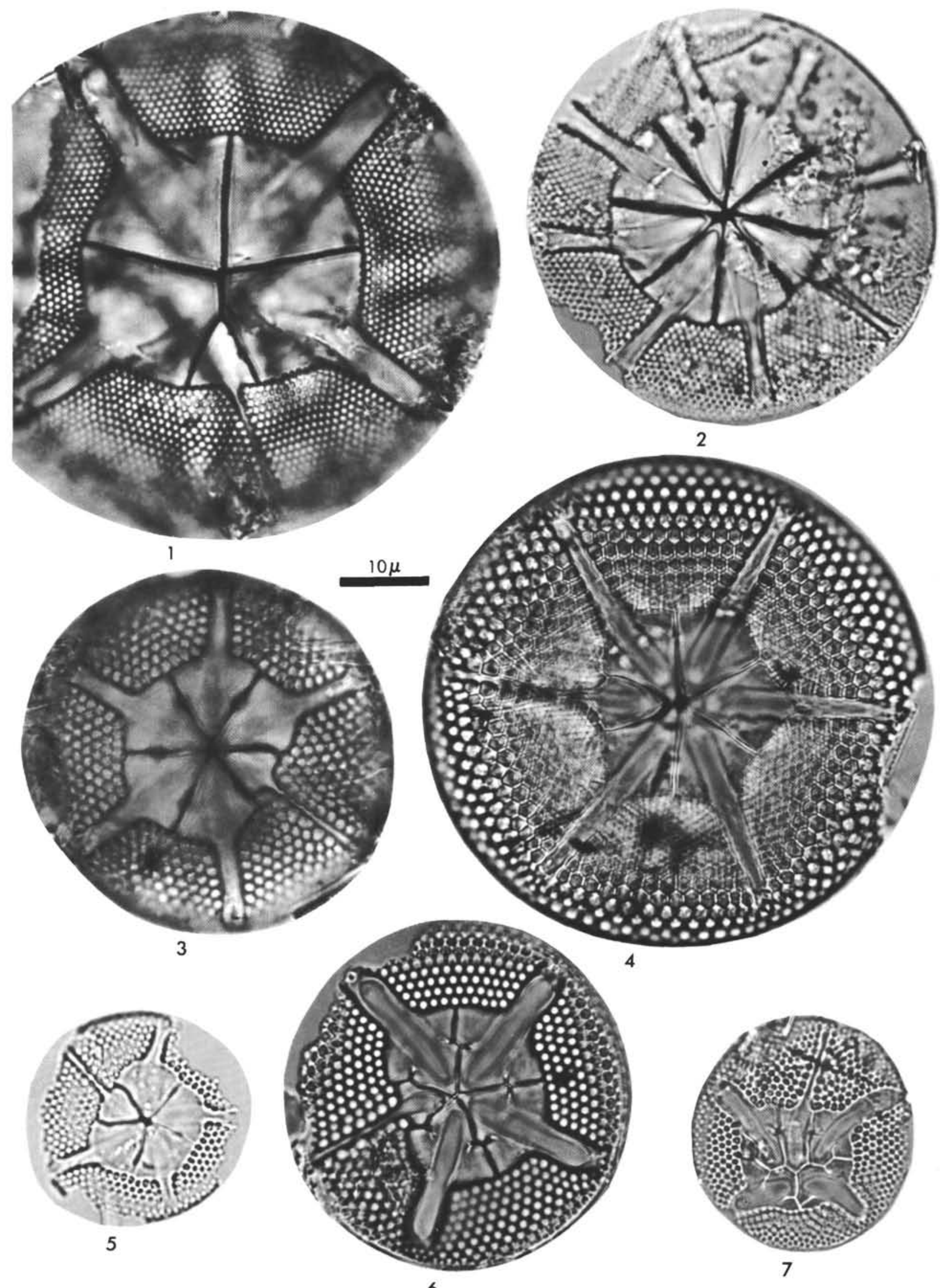
PLATE 9

(Magnification 1500×)

Figure $1 \quad$ Rhizosolenia hebetata f. hiemalis-spinosa; Sample $278-9-1,50 \mathrm{~cm}$.

Figure 2 Rhizosolenia hebetata f. hiemalis-spinosa; Sample $278-32-4,120 \mathrm{~cm}$.

Figure 3 Rhizosolenia hebetata f. hiemalis Gran; Sample 278-14-1, $50 \mathrm{~cm}$.

Figure 4 Rhizosolenia styliformis Brightwell; Sample 278$27-1,50 \mathrm{~cm}$.

Figure $5 \quad$ Rhizosolenia sp. 1; Sample 278-21-1, $50 \mathrm{~cm}$.

Figure 6 Rhizosolenia sp. 2; Sample 278-23-1, $80 \mathrm{~cm}$.

Figure $7 \quad$ Rhizosolenia oligocaenica sp. nov.; Sample 278-324, $120 \mathrm{~cm}$ (Type).

Figure 8 Chaetoceros sp. bristle; Sample 278-27-1, $50 \mathrm{~cm}$.

Figure 9 Chaetoceros sp. bristle; Sample 278-27-1, $50 \mathrm{~cm}$.

Figure $10 \quad$ Rhizosolenia alata Brightwell; Sample 278-18-1, 50 $\mathrm{cm}$.

Figure 11 Rhizosolenia barboi Brun; Sample 278-14-1, $50 \mathrm{~cm}$.

Figure 12 Rhizosolenia barboi; Sample 278-26-2, $70 \mathrm{~cm}$.

Figure 13 Rhizosolenia barboi; Sample 278-23-1, $80 \mathrm{~cm}$.

Figure 14 Rhizosolenia praebarboi Schrader; Sample 278-27$1,50 \mathrm{~cm}$. 
PLATE 9
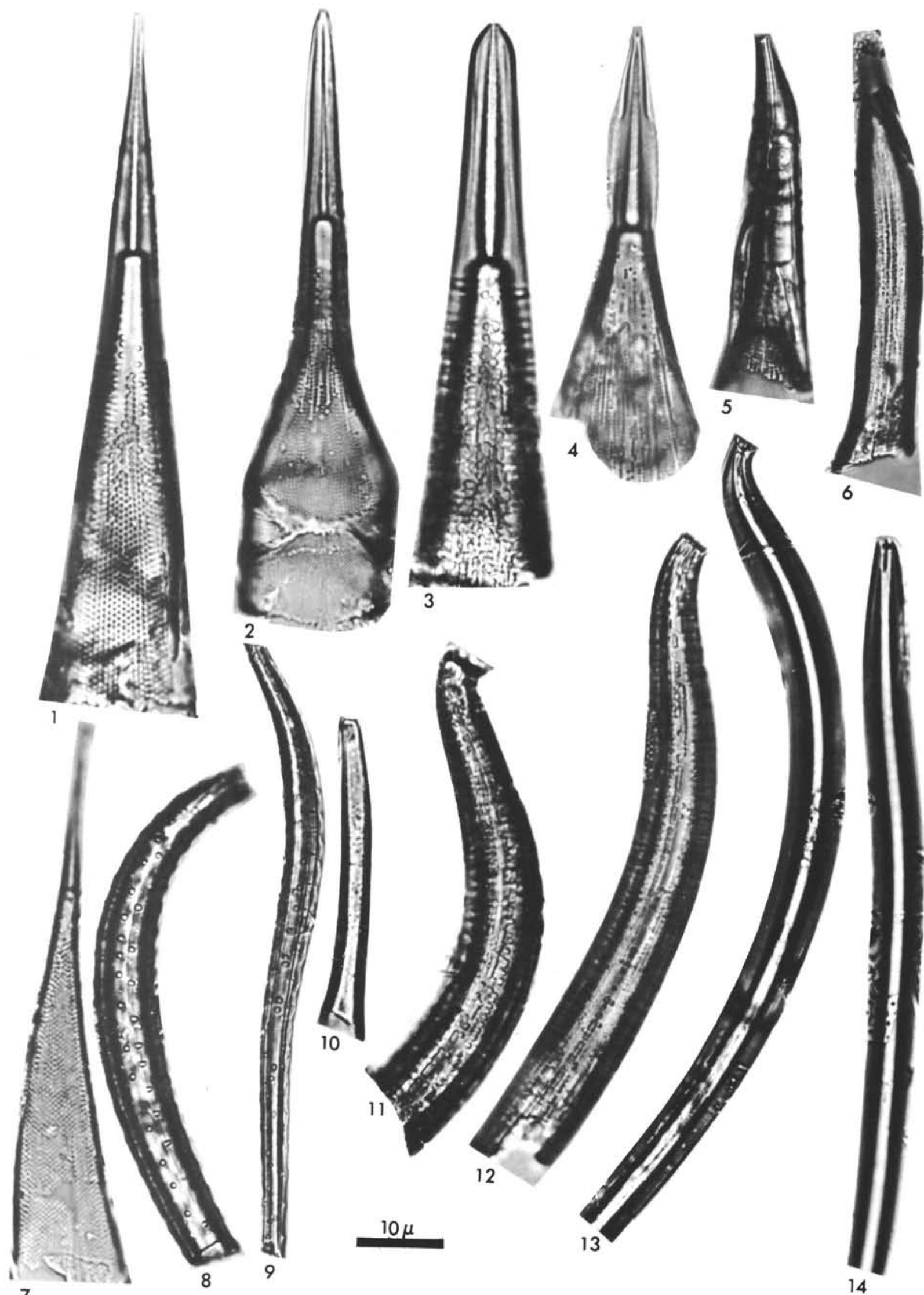


\section{PLATE 10}

(Magnification $1500 \times$ )

Figure 1 Coscinodiscus symbolophorus group 4; Sample 27823-1, $80 \mathrm{~cm}$.

Figure 2 Cestodiscus robustus Jousé; Sample 278-33-1, 50 $\mathrm{cm}$.

Figure 3 Coscinodiscus aff. marginatus Ehr.; Sample 278-12$1,50 \mathrm{~cm}$.

Figure $4 \quad$ Coscinodiscus symbolophorus group 5; Sample 278$12-1,50 \mathrm{~cm}$.

Figure $5 \quad$ Coscinodiscus symbolophorus group 6; Sample 278$12-1,50 \mathrm{~cm}$. 
PLATE 10
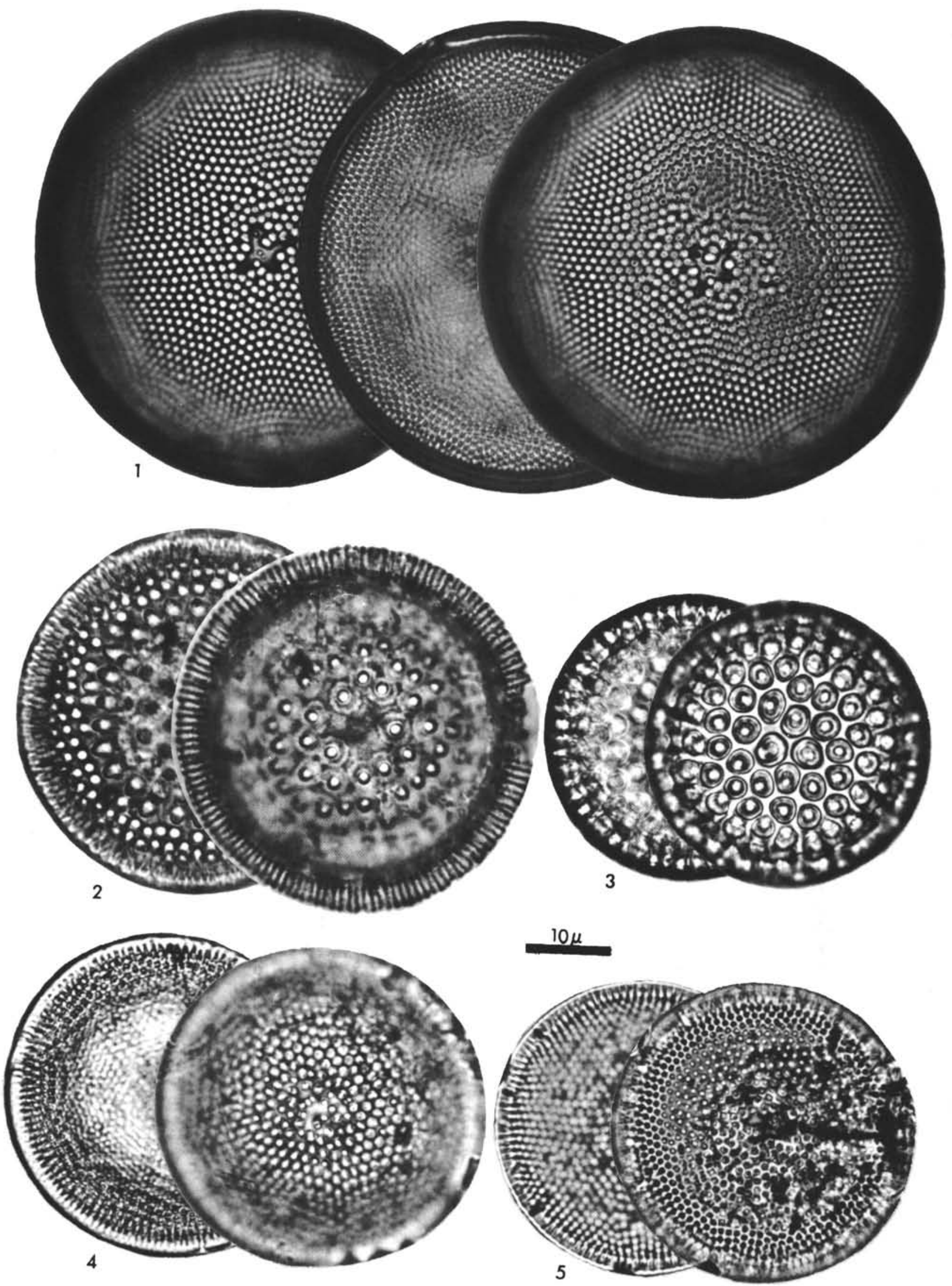


\section{PLATE 11}

(Magnification $1500 \times$ )

Figure 1 Coscinodiscus deformans sp. nov.; Sample 278-14$1,50 \mathrm{~cm}$ (Type).

Figure 2 Coscinodiscus deformans sp. nov.; Sample 278-14$1,50 \mathrm{~cm}$.

Figure 3 Coscinodiscus nodulifer A. Schmidt; Sample 278$14-1,50 \mathrm{~cm}$.

Figure 4 Coscinodiscus endoi Kanaya; Sample 278-23-1, 80 $\mathrm{cm}$.

Figure 5 Coscinodiscus tabularis Grunow; Sample 278-12-1, $50 \mathrm{~cm}$.

Figure 6 Actinocyclus aff. ingens Rattray; Sample 278-18-1, $50 \mathrm{~cm}$.

Figure 7 Actinocyclus aff. ingens; Sample 278-17-1, $50 \mathrm{~cm}$.

Figure 8 Coscinodiscus endoi; Sample 278-24-1, $50 \mathrm{~cm}$.

Figure 9 Coscinodiscus endoi; Sample 278-11-1, $50 \mathrm{~cm}$.

Figure 10 Coscinodiscus endoi; Sample 278-13-1, $50 \mathrm{~cm}$.

Figure 11 Coscinodiscus vetustissimus Pantocsek; Sample 278-14-1, $50 \mathrm{~cm}$.

Figure 12 Coscinodiscus endoi; Sample 278-14-1, $50 \mathrm{~cm}$. 

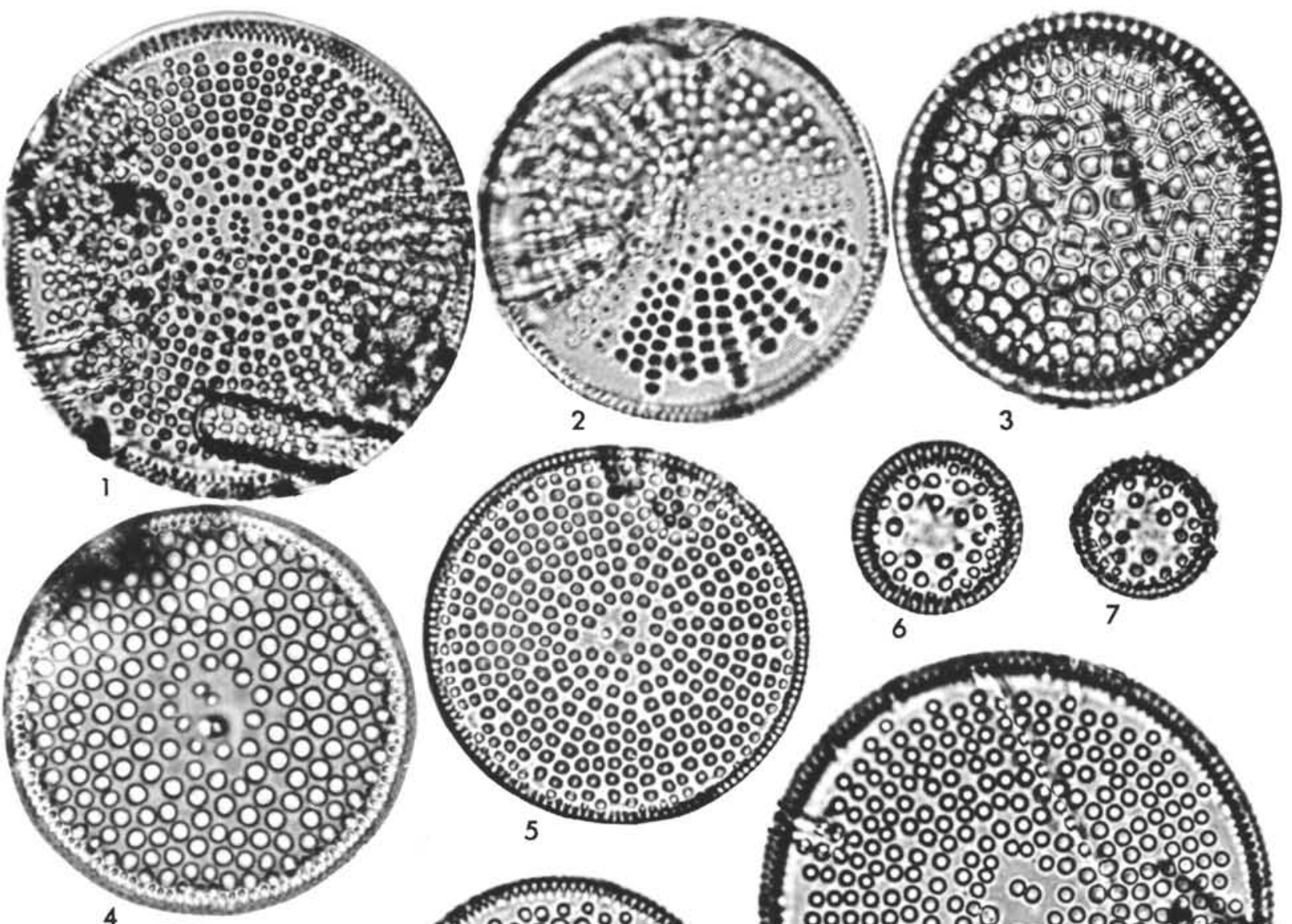

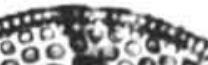
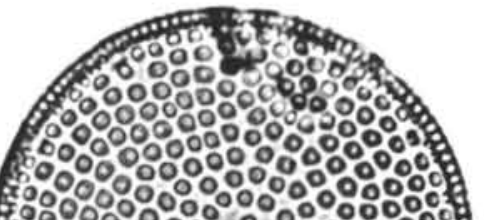

\% $0.0 \% 0 \% \%$

$0000 \% 20 \%$

$1008250 \% 0 \%$

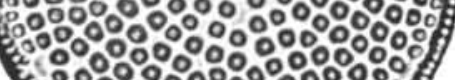

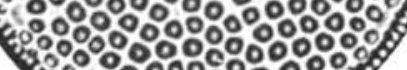

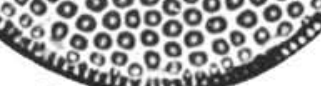

5

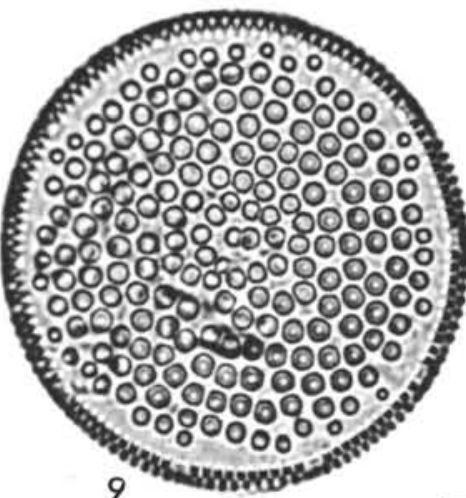

\section{E}
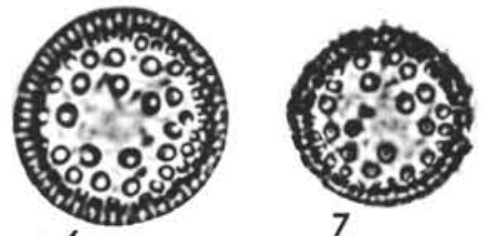

6

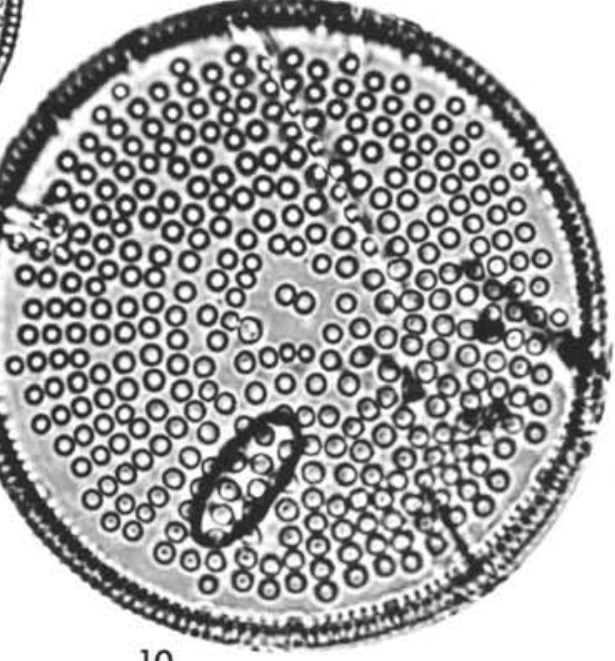

10

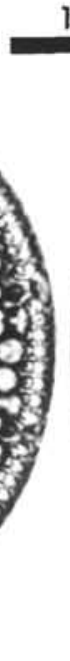

$10 \mu$ 
PLATE 12

(Magnification $1500 \times$ )

Figure 1 Cestodiscus sp. 4; Sample 278-13-1, $50 \mathrm{~cm}$.

Figure 2 Coscinodiscus marginatus Ehr.; Sample 278-29-4, $20 \mathrm{~cm}$.

Figure 3 Cestodiscus sp. 5; Sample 278-32-6, $50 \mathrm{~cm}$.

Figure 4 Cestodiscus sp. 6; Sample 278-29-4, $20 \mathrm{~cm}$.

Figure $5 \quad$ Coscinodiscus vigilans A. Schmidt; Sample 278-32$6,50 \mathrm{~cm}$.

Figure 6 Cestodiscus sp. 1; Sample 278-13-1, $50 \mathrm{~cm}$.

Figure 7 Cestodiscus sp. 2; Sample 278-14-1, $50 \mathrm{~cm}$.

Figure $8 \quad$ Thalassiosira nativa Shes.-Poretzkaya; Sample $278-9-1,50 \mathrm{~cm}$.

Figure 9 Thalassiosira nativa; Sample 278-9-1, $50 \mathrm{~cm}$.

Figure 10 Thalassiosira nativa; Sample 278-9-1, $50 \mathrm{~cm}$.

Figure 11 Thalassiosira nativa; Sample 278-9-1, $50 \mathrm{~cm}$.

Figure 12 Thalassiosira sp. 8; Sample 278-23-1, $80 \mathrm{~cm}$.

Figure 13 Cosmiodiscus intersectus (Brun) Jousé; Sample 278-13-1, $50 \mathrm{~cm}$.

Figure 14 Genus et species indet.; Sample 278-17-1, $50 \mathrm{~cm}$.

Figure 15 Cestodiscus sp. 3; Sample 278-27-1, $50 \mathrm{~cm}$. 
PLATE 12

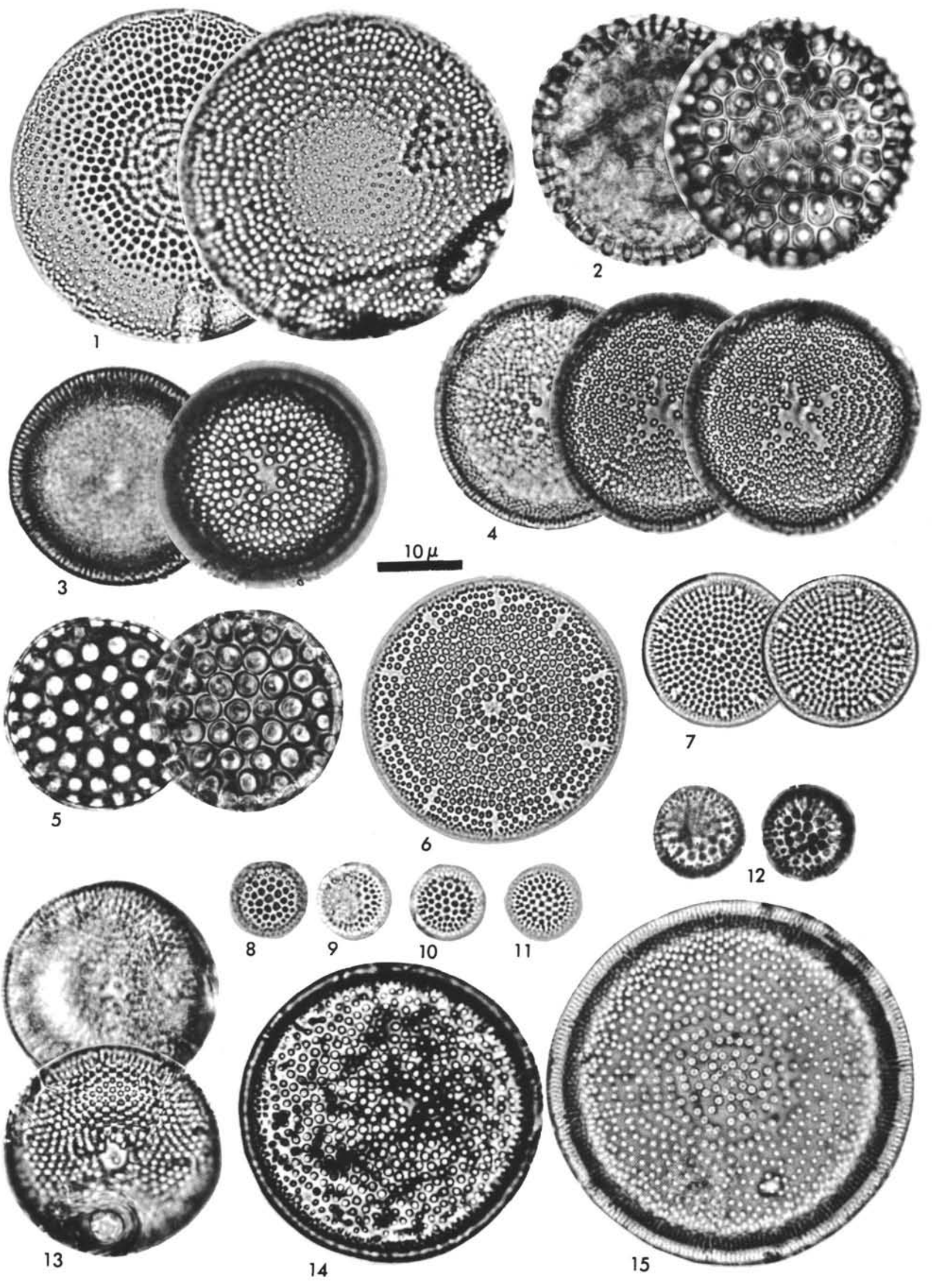




\section{PLATE 13}

(Magnification $1500 \times$ )

Figures 1,2 Coscinodiscus aff. lineatus Ehr.; Sample 278-27-1, $50 \mathrm{~cm}$.

Figure 3 Cestodiscus sp. 7; Sample 278-32-6, $50 \mathrm{~cm}$.

Figure 4a Thalassiosira sp. 9; Sample 278-14-1, $50 \mathrm{~cm}$.

Figure 4b Thalassiosira sp. 9; Sample 278-14-1, $50 \mathrm{~cm}$.

Figure 5 Cestodiscus pulchellus Greville; Sample 278-34-2, $20 \mathrm{~cm}$.

Figure 6 Cestodiscus sp. 8; Sample 278-29-3, $50 \mathrm{~cm}$.

Figure 7 Stephanopyxis "turris" (Grev. and Arn.) Ralfs; Sample 278-34-3, $50 \mathrm{~cm}$.

Figure 8 Actinocyclus ingens Rattray; Sample 278-14-1, 50 $\mathrm{cm}$. 
PLATE 13
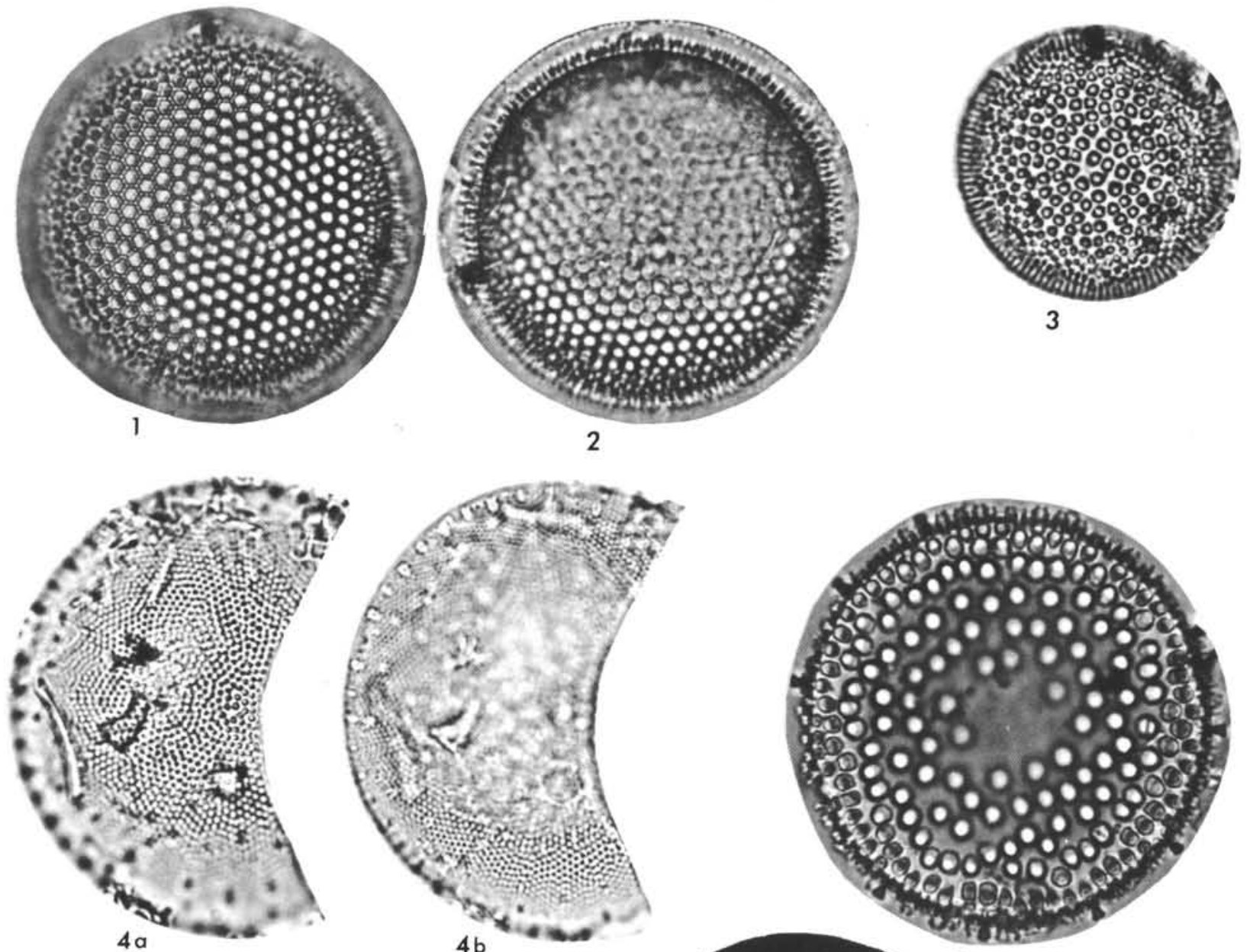

$x^{2}$

by

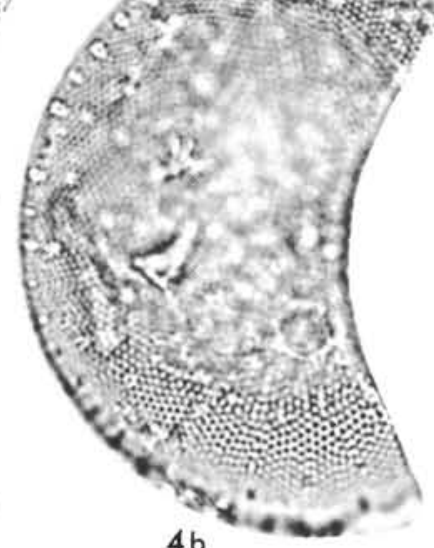

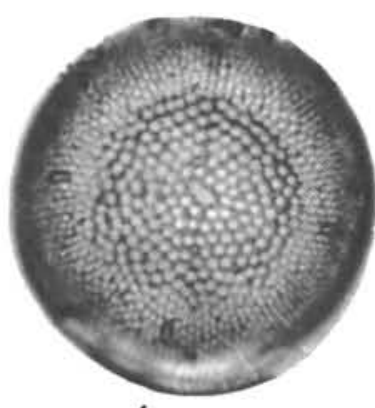

6

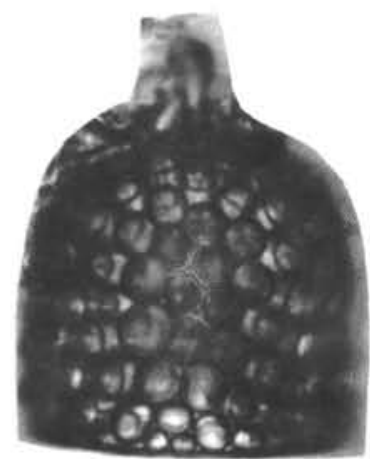

7
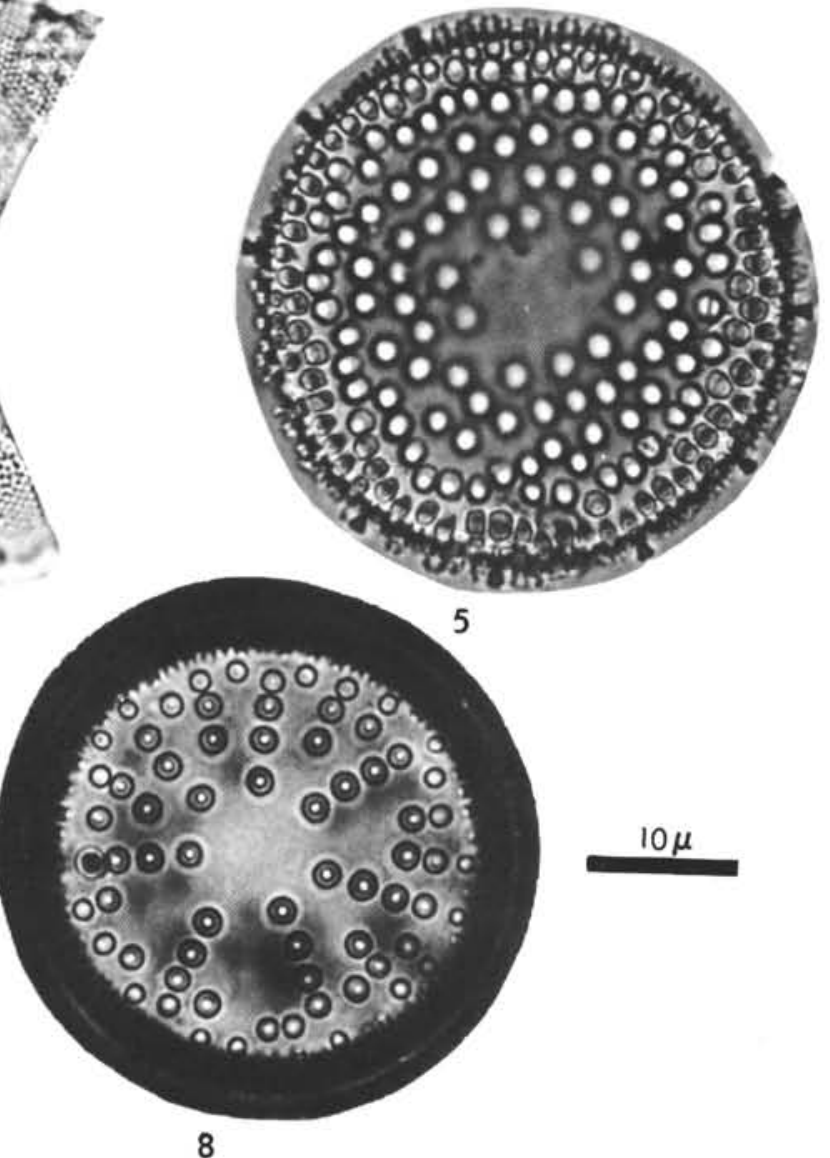

$10 \mu$ 
PLATE 14

(Magnification $1500 \times$ )

Figure $1 \quad$ Bruniopsis mirabilis (Brun) Karsten; Sample 278$14-1,50 \mathrm{~cm}$.

Figure 2 Hemidiscus karstenii Jousé; Sample 278-9-1, 50 $\mathrm{cm}$.

Figure 3 Coscinodiscus lewisianus Greville; Sample 278-19$2,50 \mathrm{~cm}$.

Figure 4 Xanthiopyxis oblonga Ehr.; Sample 278-34-2, 20 $\mathrm{cm}$.

Figures 5, 6 Goniothecium odontella Ehr.; Sample 278-34-2, 20 $\mathrm{cm}$.

Figure $7 \quad$ Eucampia balaustium Castracane; Sample 278-13$1,50 \mathrm{~cm}$.

Figure 8 Hemiaulus sp. 5; Sample 278-32-5, $50 \mathrm{~cm}$.

Figure 9 Genus et species indet.; Sample 278-32-5, $50 \mathrm{~cm}$.

Figure $10 \quad$ Pterotheca sp. 1; Sample 278-10-1, $50 \mathrm{~cm}$.

Figure $11 \quad$ Macrora stella (Azpeitia) Hanna; Sample 278-29$3,50 \mathrm{~cm}$.

Figure 12 Macrora stella; Sample 278-32-4, $120 \mathrm{~cm}$.

Figure $13 \quad$ Rhaphoneis sp. 1; Sample 278-9-1, $50 \mathrm{~cm}$.

Figure 14 Genus et species indet.; Sample 278-20-2, $60 \mathrm{~cm}$.

Figure 15 Trinacria excavata Heiberg; Sample 278-14-1, 50 $\mathrm{cm}$. 
PLATE 14

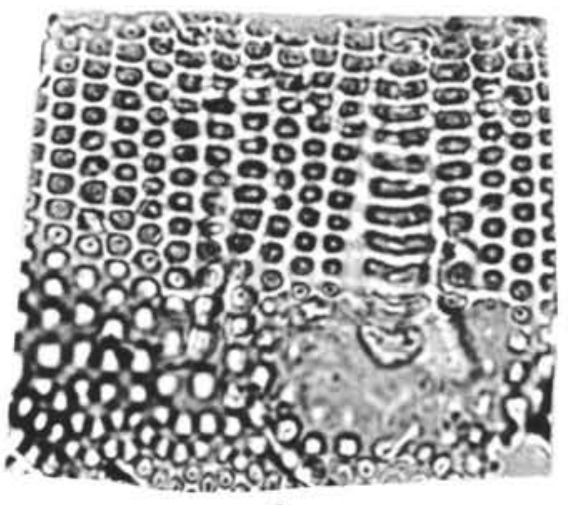

1
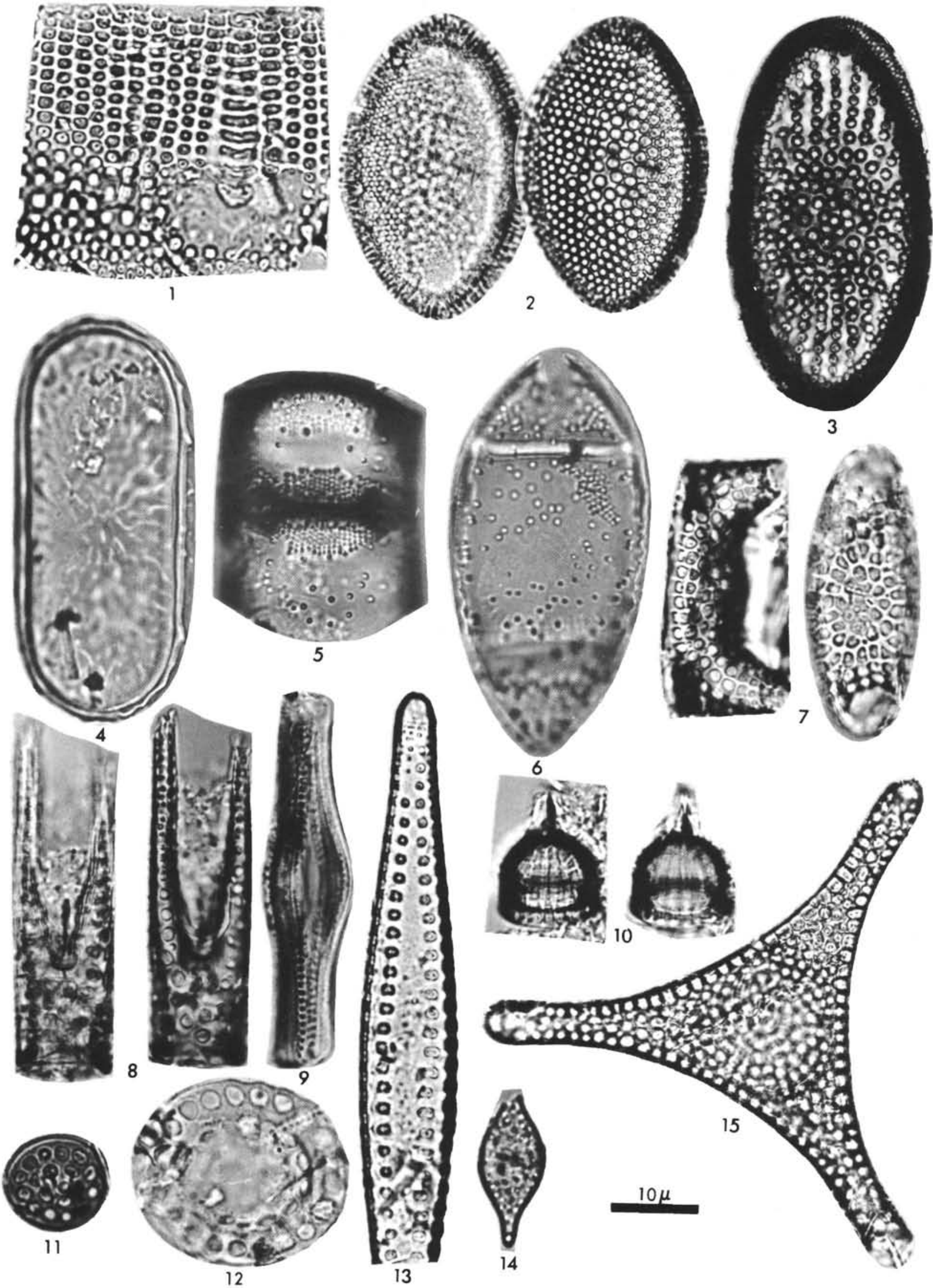


\section{PLATE 15 \\ (Magnification $1500 \times$, except Figure $4=550 \times$ )}

Figure $1 \quad$ Rhizosolenia minima sp. nov.; Sample 278-9-6, 50 $\mathrm{cm}$.

Figures 2, $3 \quad$ Rhizosolenia minima sp. nov.; Sample 278-14-1, 50 cm (Type).

Figures 4, $5 \quad$ Rouxia elongata sp. nov.; Sample 278-20-6, $50 \mathrm{~cm}$ (Type).

Figure 6 Thalassiosira sp. 10; Sample 278-11-2, $50 \mathrm{~cm}$.

Figures 7, 8 Thalassiosira sp. 10; Sample 278-11-2, $50 \mathrm{~cm}$.

Figures 9, 10 Thalassiosira convexa var. aspinosa Schrader; Sample $278-11-1,50 \mathrm{~cm}$.

Figures 11, 12 Thalassiosira sp. 9; Sample 278-11-1, $50 \mathrm{~cm}$.

Figure $13 \quad$ Nitzschia pseudokerguelensis sp. nov.; Sample 278$11-2,50 \mathrm{~cm}$.

Figures 14, 15 Nitzschia pseudokerguelensis sp. nov.; Sample 278$16-4,50 \mathrm{~cm}$, (Type).

Figure $16 \quad$ Raphidodiscus marylandicus Christian; Sample $278-20-6,50 \mathrm{~cm}$.

Figures 17, 18 Hemidiscus karstenii Jousé; Sample 278-9-4, 50 $\mathrm{cm}$.

Figure 19 Nitzschia sp. 18; Sample 278-10-3, $50 \mathrm{~cm}$.

Figure $20 \quad$ Nitzschia sp. 19; Sample 278-16-4, $50 \mathrm{~cm}$.

Figure $21 \quad$ Nitzschia curta (Van Heurck) Hasle; Sample 278$16-4,50 \mathrm{~cm}$.

Figure 22 Nitzschia denticuloides sp. nov.; Sample 278-11-1, $50 \mathrm{~cm}$.

Figure 23 Nitzschia curta; Sample 278-16-4, $50 \mathrm{~cm}$.

Figure 24 Nitzschia curta; Sample 278-16-4, $50 \mathrm{~cm}$. 
PLATE 15

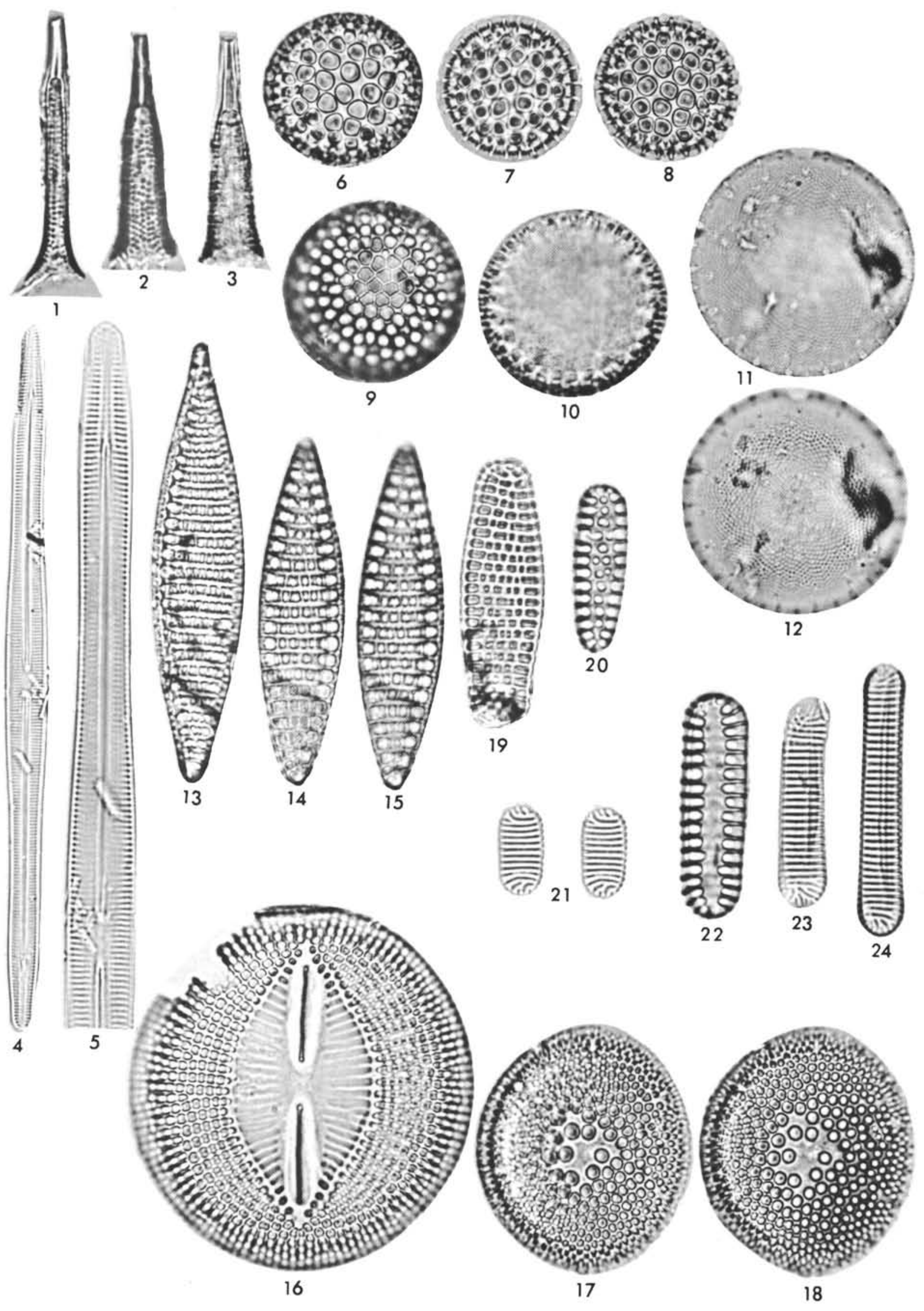

